\title{
Predição de genes ab initio combinada com informações de alinhamento
}

\author{
Bruno Tenório da Silveira Lopes \\ DISSERTAÇÃO APRESENTADA \\ $\mathrm{AO}$ \\ Instituto DE MATEMÁticA E EstatísticA \\ DA \\ UNIVERSIDADE DE SÃO PAULO \\ PARA \\ OBTENÇÃO DO TÍTULO \\ $\mathrm{DE}$ \\ Mestre EM CiÊnCIAS
}

Programa de Pós-Graduação em Ciências da Computação

Orientador: Prof. Dr. Alan Mitchell Durham

Durante o desenvolvimento deste trabalho o autor recebeu auxílio financeiro da CNPq 
Predição de genes ab initio combinada com informações de alinhamento 


\section{Agradecimentos}

Agradeço a Deus, aos meus pais José e Maria, meu irmão Vinícius e minha namorada Rafaella pelo apoio recebido nessa longa jornada. Agradeço a ajuda técnica e a paciência de Renato Cordeiro que foram essenciais durante todo o período desse trabalho. Agradeço a ajuda Ígor Bonadio. Agradeço aos amigos Armando e Dennis José. Agradeço aos amigos que fiz nesse período e ao grupo de pesquisa por toda aprendizagem.

Agradeço ao Prof. Dr Alan Mitchell Durhan pela orientação e boas contribuições feitas nesse trabalho.

Agradeço a todos do IME e à USP. Agradeço ao CNPq pelo apoio financeiro recebido. 


\section{Resumo}

Lopes, Bruno Tenório da Silveira. Predição de genes $a b$ initio combinada com informações de alinhamento. 2019. 70 p. Dissertação (Mestrado) - Instituto de Matemática e Estatística, Universidade de São Paulo, São Paulo, 2019.

Na Bioinformática, o campo de pesquisa de predição computacional de genes codificadores de proteínas é um dos mais desafiadores e não sofreu muitos avanços na última década. Há basicamente dois grupos de métodos para predição de genes: métodos ab initio e métodos extrínsecos. O grupo $a b$ initio ou intrínseco reúne os programas que realizam a predição apenas utilizando como entrada a sequência alvo. Esse grupo foca na busca por estruturas gênicas baseadas em sinais biológicos e trechos conservados. O outro grupo, chamado de extrínseco, reúne os programas que necessitam de outras sequências (de referência), além da sequência alvo para realizar a predição por meio do alinhamento da sequência alvo contra sequências de referência. Há também abordagens de predição, chamadas de híbridas, que tentam unir os dois métodos de predição incorporando alinhamentos para aumentar a precisão dos preditores ab initio. Nesse trabalho desenvolvemos uma extensão do arcabouço probabilístico ToPS para implementar duas técnicas de abordagens híbridas de predição e avaliar seus benefícios e méritos relativos. Os resultados obtidos mostram um claro benefício da inclusão de alinhamentos de genomas na predição, e prós e contras da inclusão de mapeamentos de transcritos. Além disso, construímos um modelo genérico para incluir num preditor de genes informações probabilísticas externas. Esse modelo é implementado no ToPS e pode ser usado para desenvolver mais estratégias de predição de genes.

Palavras-chave: modelos probabilísticos, predição de genes, cadeia de markov oculta generalizada, aprendizado de máquina, bioinformática. 


\section{Abstract}

Lopes, Bruno Tenório da Silveira Ab initio gene prediction combined with alignment information. 2019. 70 p. Dissertation (Masters) - Instituto de Matemática e Estatística, Universidade de São Paulo, São Paulo, 2019.

In Bioinformatics, the field of computational prediction of protein-coding genes is one of the most challenging and did not have many advances in the last decade. There are two main groups of methods for predicting genes: $a b$ initio methods and extrinsic methods. The ab initio or intrinsic group includes the programs that perform the prediction using only the target sequence as input. This group focuses on the search for gene structures based on biological signals and preserved portions of the sequence. The other group, called extrinsic, consists of the programs that require other (reference) sequences in addition to the target sequence to perform the prediction by aligning the target sequence against reference sequences. There are also prediction approaches that attempt to join the two prediction methods, called the hybrid, incorporating alignments to increase the precision of the $a b$ initio predictors. In this dissertation we developed an extension of the ToPS computational framework to implement two hybrid prediction techniques and assess their benefits and relative merits. The results obtained show a clear benefit from including genome alignments in the prediction and the pros and cons of using transcript mapping. Additionally, we have devised a generic model to include probabilistic extraneous information into a gene predictor. This model is implemented in ToPS and can be used to further develop gene prediction strategies.

Keywords: probabilistic models, gene prediction, generalized hidden markov model, machine learning, bioinformatics. 


\section{Sumário}

$\begin{array}{ll}\text { Lista de Figuras } & \text { ix }\end{array}$

Lista de Tabelas $\quad$ xv

1 Introdução $\quad \mathbf{1}$

1.1 Organização do texto . . . . . . . . . . . . . . . . . . . . . 3

2 Conceitos de Biologia Molecular $\mathbf{5}$

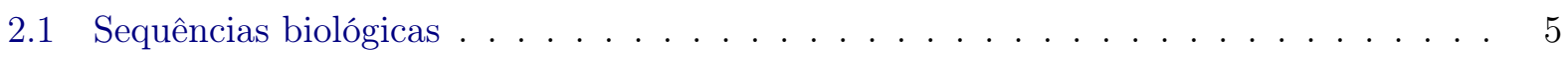

2.2 Transcrição e tradução . . . . . . . . . . . . . . . . . . . . . . . . 7

2.3 Genes codificadores de proteínas . . . . . . . . . . . . . . . 8

3 Modelos Probabilísticos de Markov $\quad 13$

3.1 Cadeias de Markov . . . . . . . . . . . . . . . . . . . . . . . . 13

3.2 Modelos Ocultos de Markov - HMM . . . . . . . . . . . . . . . . . 15

3.2 .1 Algoritmo de Viterbi HMM . . . . . . . . . . . . . . . . . . . 18

3.3 Modelos Ocultos de Markov Generalizados - GHMM . . . . . . . . . . . . . . . 19

3.3.1 Algoritmo de Viterbi GHMM . . . . . . . . . . . . . . . . . . . 20

4 Predição de genes $\quad 21$

4.1 Predição extrínseca . . . . . . . . . . . . . . . . . . . . . . . . . . 22

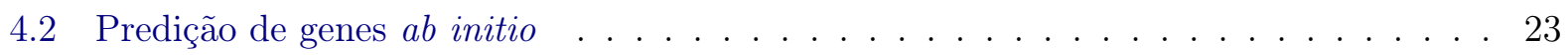

$4.2 .1 \quad$ Preditores $a b$ initio . . . . . . . . . . . . . . . . . . . . . . . 23

4.3 Predição híbrida de genes . . . . . . . . . . . . . . . . . . . . . 29

4.4 Predição com múltiplas fontes . . . . . . . . . . . . . . . . . . . . . . . 29

5 Métodos de predição híbrida $\quad 31$

5.1 Método de predição utilizado no Twinscan . . . . . . . . . . . . . . . . . 31

5.2 Método utilizado no Augustus $+\ldots \ldots \ldots$. . . . . . . . . . . . . . . 33

6 Um preditor com contribuições extrínsecas de fontes de alinhamento $\quad 37$

6.1 Uma proposta de modificação do Algoritmo de Viterbi . . . . . . . . . . . . . . . 37

6.2 Implementação da modelagem unificada de contribuições extrínsecas . . . . . . . . . 40

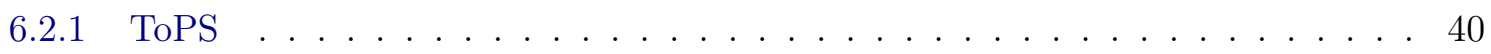

6.2 .2 Arquitetura do ToPS . . . . . . . . . . . . . . . . . 41

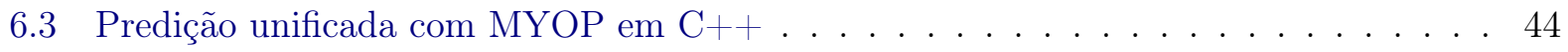


6.3 .1 Extensão do ToPS . . . . . . . . . . . . . . . . . . . . 46

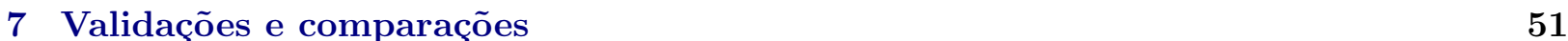

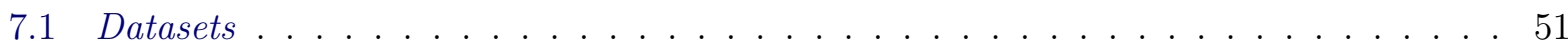

7.2 Metodologia de validação . . . . . . . . . . . . . . . . . . . 52

7.3 Validação do algoritmo Augustus implementado no MYOP C $++\ldots \ldots$. . . . . . . . 53

7.4 Validação do algoritmo Twinscan implementado no MYOP $\mathrm{C}++\ldots \ldots$. . . . . . . 60

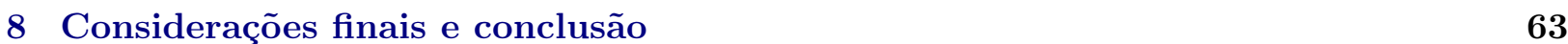

Referências Bibliográficas $\quad 65$ 


\section{Lista de Figuras}

1.1 Fonte (Muir et al., 2016). Rápida redução dos custos do sequenciamento por genoma. 1

1.2 Fonte: (Lesk, 2014). (a) Crescimento dos bancos de dados de sequências de nucleotídeos. (b) Crescimento do Protein Data Bank. . . . . . . . . . . . . . . . . . . . . . .

2.1 Fitas moldes parentais em azul e fitas recém-sintetizadas em rosa. Na replicação do DNA, as duas cadeias da dupla-hélice (em azul) se desenrolam e se separam para que duas novas cadeias (em rosa) sejam sintetizadas, cada uma com uma sequência complementar correspondente uma das cadeias parentais. O resultado da replicação são duas moléculas de dupla-hélice idênticas, cada uma constituída por uma cadeia que veio do DNA parental e outra cadeia recém-sintetizada (Lehninger et al., 2012).

2.2 Dogma Central da Biologia Molecular, a via do DNA à proteína. O fluxo da informação genética do DNA ao RNA (transcrição) e do RNA à proteína (tradução) define a expressão gênica que ocorre em todas as células vivas. (Alberts et al., 2017). . . . . .

2.3 Código Genético (Moreira, 2015) que relaciona os códons do DNA e os aminoácidos

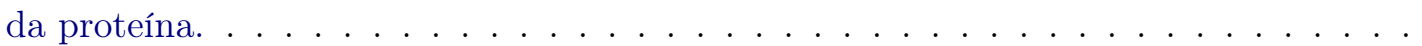

2.4 A estrutura de uma molécula típica de mRNA bacteriano. Os ribossomos procariotos iniciam a tradução em sítios de início (AUG) que podem estar localizados em qualquer lugar ao longo de uma molécula de mRNA. Isso permite que a sintetize de mais de um tipo de proteína a partir de uma única molécula de mRNA. (Alberts et al., 2017).

2.5 Fonte (Axelson-Fisk, 2015). A estrutura de um gene eucariótico. O gene é definido como o segmento que é transcrito em RNA. A sequência codificadora consiste de éxons que são traduzidos em aminoácidos e estão separados por íntrons que são removidos antes da tradução e que não codificam proteína. A região inicial do primeiro éxon e a região final do último éxon e as regiões 5'UTR e 3'UTR são regiões não traduzidas. As regiões 5'UTR e 3'UTR flanqueiam a sequência codificadora e não estão envolvidas na síntese de proteína. A região promotora contém sítios de ligação (tais como CAAT e TATA) para enzimas envolvidas na transcrição. As regiões que delimitam éxons e íntrons são chamadas de sítios doadores de íntron (splice donor) que marcam o início de íntrons e sítios aceitares de íntron (acceptor site) que marcam o fim de íntrons. Em geral, sítios doadores contém a sequência conservada GT e sítios aceitadores contém a sequência AG. . . . . . . . . . . . . . . . . . . . . . . . . . . . . 10 
2.6 Um exemplo de splicing alternativo do pré-RNA de $\alpha$-tropomiosina. O transcrito primário de $\alpha$-tropomiosina pode ter seus íntrons retirados de 5 diferentes maneiras e produzir 5 mRNAs distintos: mRNA de músculo estriado, mRNA de músculo liso, duas possibilidades de mRNAs de fibroblasto e mRNA de encéfalo. Como resultado, mRNAs diferentes dão origem a proteínas diferentes. (Alberts et al., 2017) . . . . . . 11

3.1 Uma cadeia de Markov para modelar três estados de uma pessoa durante seu dia: triste, feliz e muito feliz. A probabilidade de se iniciar em qualquer um dos três estados é a mesma, 1/3. Como as arestas que chegam no estado feliz possuem valores duas vezes maiores que as demais arestas, a pessoa modelada por essa cadeia de Markov tende a ficar no estado feliz mais tempo do que nos estados triste ou muito feliz

3.2 HMM para modelar uma pessoa fictícia depressiva. Seja $t, f, m$ símbolos que denominam triste, feliz, e muito feliz. O estado de depressão (em cinza, é representado por $d$ em $\left.e_{d}\left(X_{i}\right)\right)$ possui a probabilidade de emissão do símbolo triste $e_{d}(t)=1 / 2 \mathrm{e}$ a probabilidade dos símbolos de feliz e muito feliz $e_{d}(f)=e_{d}(m)=1 / 4$. Além disso, a HMM inicia no estado de depressão e a sua aresta de auto-transição é 9/10 conduzindo a HMM continuar nesse estado e emitir mais símbolos de tristeza modelando a dificuldade encontrada por pessoas com depressão a sair desse estado. . . . . . . . . 17

4.1 Sítios gênicos conservados $($ Moreira, 2015) . . . . . . . . . . . . . . . . 21

4.2 Cada caixa corresponde a um submodelo com mais de um estado. O número acima de cada caixa representa o número de bases modeladas pelo submodelo da caixa e 'X' indica um número variável. Como o modelo busca identificar ORFs na sequência, estados da vizinhança do códon início e fim são modelados (RBS, ASTART e BSTOP e ASTOP respectivamente) são modelados para reforçar o sinal de códon de início e fim. Os três loops para compor a região codificadora foram escolhidos especificamente para se obter um ajuste empírico de distribuição de tamanhos mais realista do que a distribuição de tamanhos da HMM (com um loop) que é intrinsecamente geométrica. (Larsen e Krogh, 2003). . . . . . . . . . . . . . . . . . . . . .

4.3 Os estados da GHMM do Genscan. Para modelar a análise dos dois sentidos da sequência (5'3' e 3'5'), Genscan constrói uma GHMM conectando no estado $N$ (região intergênica) duas GHMM, uma para o modelo da estrutura do gene eucarioto no sentido 5'3' e a outra, o espelho dessa, para o modelo da estrutura do gene no sentido inverso 3'5'. O ciclo iniciado no estado $N$ permite a predição de mais de um gene numa única sequência e a ausência de estados de início e fim permite a predição de genes parciais. Todas essas características embutidas na GHMM de Genscan foram posteriores incorporados nos preditores Augustus (Stanke e Waack, 2003) e MYOP, esse último inicialmente desenvolvido por Kashiwabara (2012) . . . . . . . . . . . . 25

4.4 Os estados do Augustus e as possíveis transições entre eles. Estados representados por losangos emitem cadeias de tamanho fixo e estados representados por círculos ovais emitem cadeias de tamanho explícito. Os expoentes descrevem a fase de leitura e o números acima das arestas as probabilidades de transição (Stanke e Waack, 2003). 
4.5 Submodelo de distribuição de tamanhos de íntrons. $I_{g e o}$ emite um nucleotídeo por vez, $I_{\text {fixed }}$ emite sequências de tamanho $d$ e $I_{\text {short }}$ emite sequências de tamanho $l \leq d$. Íntrons curtos, ou seja com tamanhos $l \leq d$, com $d$ uma constante máxima que depende do organismo (exemplo $d=929$ para Drosophila e $d=584$ para humano) são modelados pelo estado $I_{\text {short }}$ com duração explícita, ou seja, a probabilidade de duração segue uma distribuição que normalmente não é uma distribuição fixa (ou constante) nem é geométrica. Íntrons com tamanhos $l>d$ são modelados com dois estados, o estado $I_{\text {fixed }}$ com distribuição de tamanho (fixo) constante $d$ e outro estado $I_{\text {geo }}$ com duração geométrica por conta da autotransição. (Stanke e Waack, 2003). . . 28

5.1 Uma sequência de DNA junto com sua correspondente sequência conservada. Figura alterada de Korf et al. (2001) . . . . . . . . . . . . . . . . . . . . . . . . 32

6.1 A matriz $M$ sintetiza toda a informação de alinhamento. Para cada trecho de tamanho d da sequência $Y$ (tamanho de uma possível duração do estado k), os pesos das contribuições extrínsecas armazenados nos campos da matriz referente a linha (associado a esse estado $k$ ) e as colunas (associados ao trecho, $i i \in(i-d, i)$ ) são acumulados na variável total_extrinsic_contribuition (linha 6-12). Esse valor acumulado é usado para ajustar a probabilidade de rotulação desse trecho com os estados $k$ associado a esse tipo de dica (linhas 14-15). Os trechos grifados destacam as partes do algoritmo responsáveis por acumular os valores da contribuição extrínseca, e juntar esse valor acumulado à variável Viterbi corrente $\left(\delta_{j}(\right.$ begin $\left.)\right)$, à probabilidade de transição do estado $j$ para o $\mathrm{k}\left(a_{j k}\right)$, à probabilidade de emissão $\left(b_{k}\left(Y_{\text {begin }}^{\text {end }}\right)\right.$ e à probabilidade de duração $\left(f_{k}(d)\right)$ do estado $k$. Uma vez determinado o maior valor de probabilidade na posição i no estado k ele é armazenado na matriz de Viterbi $\left(\delta_{j}(i)=m a x \_c a n d i d a t e\right)$, assim como são armazenado em matrizes o estado j predecessor de $\mathrm{k}\left(\psi_{k}(i)=j\right)$ e a duração do estado $\mathrm{k}\left(\phi_{k}(i)=d\right)$ (linhas 16-19). Essas três matrizes são utilizadas no final do algoritmo por um procedimento de rastreio (traceBack $(Y, \phi, \psi))$ que encontra o conjunto de estados ocultos mais prováveis (label) da GHMM para a sequência alvo $Y$ levando em conta as contribuições fornecidas pela matriz M (linha 22) . . . . . . . . . . . . . . . . . 39

6.2 Arquivo texto que especifica um modelo HMM hipotético que caracteriza o humor de pacientes com depressão e sem depressão (normal). Nesse arquivo todos os parâmetros do modelo probabilístico são definidos. . . . . . . . . . . . . . . . . . . . . . 40 
6.3 Uma classe abstrata é uma classe a qual todos os seus métodos são puramente virtuais (Stroustrup, 2013). A classe ProbabilisticModel é uma classe abstrata que declara os métodos de fábrica de Secretários (avaliadores, geradores, treinadores e serializadores de sequência) comuns a todos os modelos probabilísticos. A classe DecodableModel, outra interface, declara os métodos de fábrica de Secretários (calculadores e rotuladores de sequências) exclusivos dos modelos HMM e GHMM que realizam decodificação de sequências. Esses métodos de fábrica são implementados de modo genérico (como templates Derived) pelas classes ProbabilisticModelCrtp e DecodableModelCrtp e são sobrescritos (implementados de modo especializado) nas diferentes classes filhas, as classes de modelos probabilísticos que são as classes folhas da hierarquia do ToPS. As setas pontilhadas indicam o binding, a amarração da implementação genérica do template T (Derived) com a implementação específica da classe GeneralizedHiddenMarkovModel. . . . . . . . . . . . . . . .

6.5 A arquitetura da GHMM do MYOP $\mathrm{C}++$ simplificado é a mesma arquitetura do preditor MYOP original desenvolvida por Kashiwabara (2012) com a adição dos estados B (begin) e E (end) em azul. O estado B, primeiro estado da GHMM, não emite símbolo (estado silencioso), transita para o estado N (estado de região intergenica) com probabilidade 1 e duração 0 . O estado E, estado final, também não emite símbolo, transita para si mesmo (auto-transição) e duração 0. . . . . . . . . . . . .

6.6 As diferentes técnicas de mapeamento são subclasses de ExtrinsicTechnique e devem tratar as informações de alinhamento a sua maneira e retornar uma matriz numérica cujas linhas representam o estados e as colunas representam as posições da sequência a ser analisada. Um campo dessa matriz numérica apresenta a contribuição de um estado em uma posição da sequência. Por exemplo, a posição Matrix[1][99] da matriz de contribuição representa a contribuição que as informações de alinhamento trazem para a posição 100 no estado de 1 (start). A matriz segue o padrão do $\mathrm{C}++$, linhas e colunas são iniciadas da posição 0 . O estado da linha 0 é o estado B e o estado da linha 68 é o estado E. A coluna 0 representa a primeira posição da sequência e a coluna "tamanho da sequência - 1" representa a última posição da sequência. . . . .

7.1 O dataset é dividido em dataset de treino e dataset de teste. Do dataset de teste foram selecionados 55 genes para compor o dataset de teste final. Os mesmos datasets de treino e de teste (com 55 genes) são usados no treinamento e teste dos três algoritmos implementados. Nesse fluxo, o que difere os algoritmos Augustus e Twinscan são os datasets de sequências extrínsecas e os scripts para o processamento das mesmas. Para o algoritmo Augustus é usado o dataset de transcritos e o script blat2hints.pl, e para o algoritmo Twinscan é usado o dataset com genes do genoma informante e o script conseq.pl.

7.2 Um exemplo de arquivo de configuração extrínseca disponível no preditor Augustus. Nota-se valores de contribuição extrínseca extremamente altos $(1 \mathrm{e}+100)$ para todos os tipos de dicas de origem manual. Isso força a predição a obedecer as dicas manuais (M). Nota-se também valores 1000 (1e3) para dicas de trecho de éxon (exonpart) e valores 10000 (1e4) para dicas de éxon completo (exon) e de íntron completo (intron) originadas de alinhamentos com ESTs $(\mathrm{E}) \ldots \ldots \ldots \ldots \ldots$ 
7.3 Nesse fluxograma em forma de árvore, as folhas representam os testes que foram realizados para validar o algoritmo Augustus implementado no MYOP $\mathrm{C}++$. Com o mesmo dataset 1 foram realizados dois grupos de teste variando o conjunto de dicas utilizadas. No grupo 1 foram utilizadas as dicas limpas, que passaram pelo pré-processamento; e no grupo 2 foram utilizadas as dicas ideais, as anotações de referência dos 55 genes. . . . . . . . . . . . . . . . . . 58

7.4 Tabela com os resultados das predições no grupo 1. No grupo 1, para as dicas limpas com contribuições estimadas, foram usados os seguintes fatores de multiplicação de cada tipo de dica: exon $=0.96091, e p=0.59867$, intron $=0.52541$, sem_dicas $=$ 0.35185. E no mesmo grupo 1 para as dicas limpas com contribuições ideais, foram usados os seguintes fatores: $e x o n=e p=i n t r o n=1$ e sem_dicas $=0.35185$. Tanto nas dicas limpas com contribuições ideias quanto nas dicas com contribuições estimadas, os fatores de contribuição das dicas do tipo start e do tipo stop foram zero, pois essas dicas não apareceram nos mapeamentos e por isso não puderam ser estimados. As dicas do tipo ass e do tipo dss foram removidas durante a limpeza, dando preferência à permanência das dicas do tipo íntron nos casos em ocorriam mais de uma dica na mesma posição da sequência. . . . . . . . . . . . . . . . . . 58

7.5 Tabela com os resultados das predições no grupo 2. No grupo 2, para dicas ideais, foram usados os seguintes fatores de multiplicação para cada tipo de dica: start $=$ stop $=$ exon $=e p=$ intron $=1$ e sem_dicas $=0.35185$. O valor 0.35185 é uma estimativa utilizando o dataset de treinamento, onde 0.35185 das posições das sequências não foram mapeadas com dicas. . . . . . . . . . . . . . . . . . . . . 59

7.6 Todos os resultados dos dois grupos. As dicas ideais melhoram consideravelmente as predições em todas as métricas avaliadas enquanto as dicas limpas apresentam

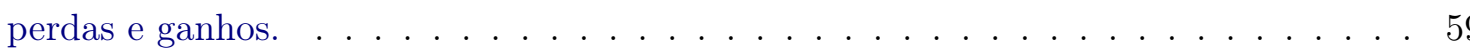

7.7 Resultado das predições em regiões sem dicas utilizando o algoritmo noHints e utilizando o algoritmo Augustus de inclusão de informação. . . . . . . . . . . . . 60

7.8 Nesse fluxograma em forma de árvore, as folhas representam os testes que foram realizados para validar o algoritmo Twinscan implementado no MYOP $\mathrm{C}++$. No dataset 1 foram realizadas predições usando as sequências de conservação geradas pelo script conseq.pl que obtiveram ao menos um caracter de match ("."). No dataset 2 foram realizadas predições sem o uso de sequências de conversação. . . . . . . . . . . 61

7.9 Resultado das predições realizadas no dataset 1 utilizando a implementação do algoritmo Twinscan de uso de informação extrínseca de alinhamento genômico e das predições realizadas utilizando o algoritmo noHints . . . . . . . . . . . . 61 61

7.10 Resultado de predições com e sem o algoritmo Twinscan de inclusão de informação extrínseca em regiões sem alinhamentos . . . . . . . . . . . . . . . . 62

7.11 Todos os resultados de predição nos dois datasets. . . . . . . . . . . . . . . . 62 


\section{Lista de Tabelas}

6.1 Esta tabela associa o tipo de dica e os estados aos quais ele exerce influência de contribuição. Não é mostrado os estados silenciosos (B e E) e estado de região intergenica $(\mathrm{N})$, pois esses não recebem contribuições extrínsecas . . . . . . . . . . . . . 48

6.2 Esta tabela associa cada um dos 5 conjuntos de trechos (de sequência de conservação de treinamento) usados para treinar as 5 Cadeias de Markov de ordem 5 e os estados aos quais essas Cadeias de Markov exercem influência de contribuição. Não é mostrado os estados silenciosos (B e E), pois esses não recebem contribuições

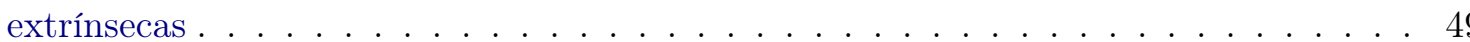




\section{Capítulo 1}

\section{Introdução}

O genoma de um organismo é o conjunto completo de DNA, incluindo seus genes, contendo toda a informação necessária para manter e construir esse organismo (U.S. National Library of Medicine, 2018). Os avanços nas técnicas de sequenciamento do DNA como o sequenciamento de nova geração têm permitido uma redução drástica dos custos de sequenciamento de genomas (Muir et al., 2016) possibilitando o crescente aumento no número de genomas disponíveis nos bancos de dados públicos (Figura 1.2). Contudo, os métodos biológicos de análise ainda são caros e não têm escala suficiente para acompanhar o ritmo das técnicas de sequenciamento, por isso a análise computacional desse grande volume de informação é imprescindível.

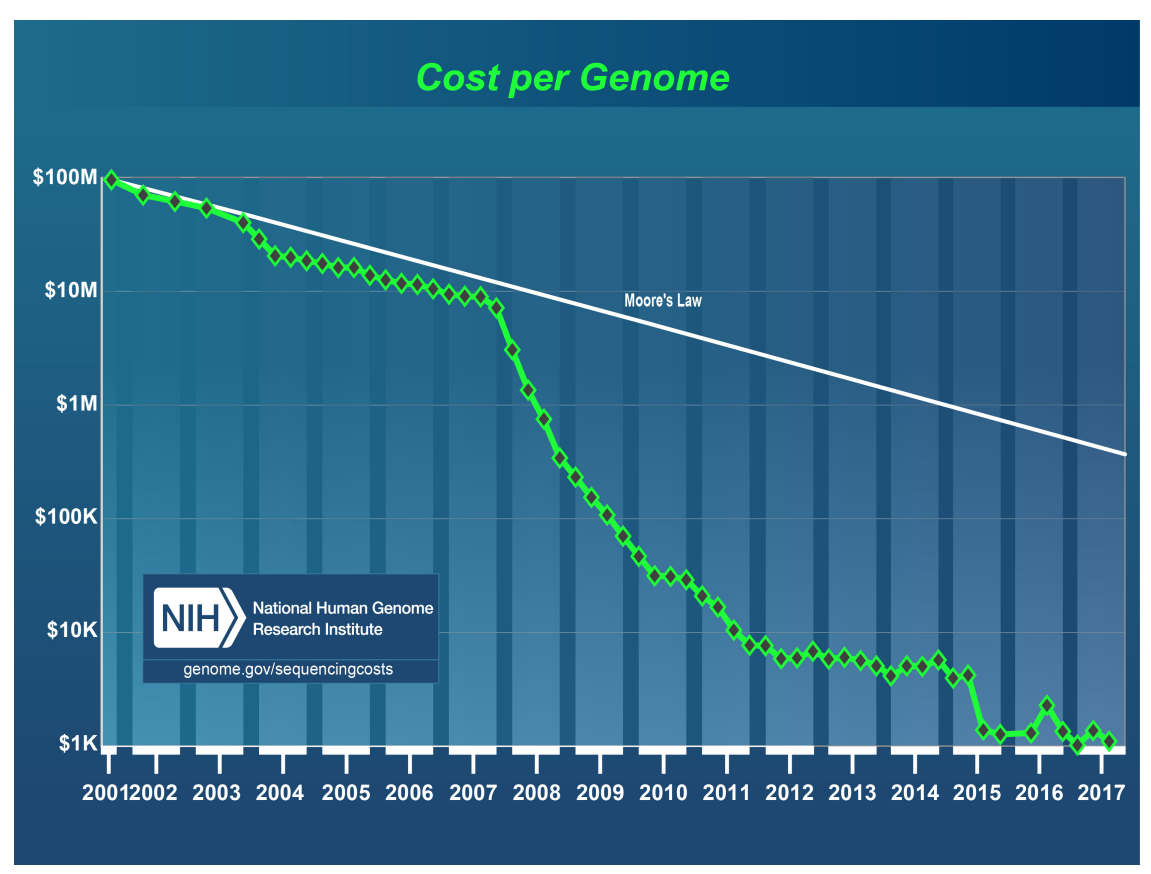

Figura 1.1: Fonte (Muir et al., 2016). Rápida redução dos custos do sequenciamento por genoma.

Nesse contexto, a Bioinformática tornou-se fundamental unindo diversas áreas do conhecimento como Biologia, Física, Química e Computação para desenvolver ferramentas que apoie a compreensão do significado biológico representado nos dados genômicos. A Bioinformática pode ser definida como uma modalidade que abrange todos os aspectos de aquisição, processamento, armazenamento, distribuição, análise e interpretação da informação biológica (Santos e Ortega, 2003). 

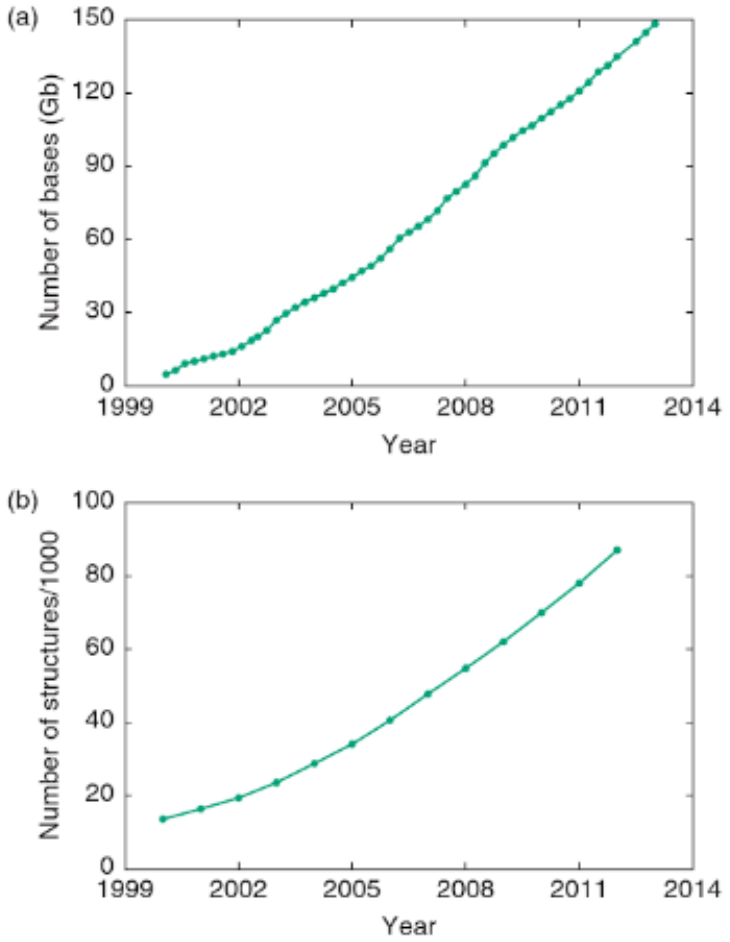

Figura 1.2: Fonte: (Lesk, 2014). (a) Crescimento dos bancos de dados de sequências de nucleotídeos. (b) Crescimento do Protein Data Bank.

As técnicas para encontrar genes em laboratório são normalmente restritas à análise de um gene ou um grupo de genes relacionados. Além disso alguns genes só são expressos em determinadas condições cuja reprodução in vitro para sua identificação se torna muito difícil. Por exemplo, a produção da hemoglobina fetal, $\mathrm{HbF}$, é gradualmente substituída pelas hemoglobinas adultas A2 e A desde o nascimento humano até praticamente cessar no sexto mês de vida (Costa et al., 2002). Esses desafios motivaram o desenvolvimento de metodologias de predição de genes in silico.

Há basicamente dois grupos de métodos para predição de genes. O grupo ab initio ou intrínseca que reúne os programas que realizam a predição apenas utilizando como entrada a sequência alvo. Esse grupo foca na busca por estruturas gênicas baseadas em sinais biológicos e trechos conservados. São exemplos de preditores ab initio os programas EasyGene (Larsen e Krogh, 2003), Genscan (Burge e Karlin, 1997) e Augustus (Stanke e Waack, 2003).

O outro grupo, chamado de extrínseco, reúne os programas que necessitam de outras sequências (de referência), além da sequência alvo para realizar a predição. Os programas desse grupo realizam alinhamentos da sequência alvo contra sequências de referência. Por basicamente realizarem alinhamentos, muitas vezes esses programas não são chamados de preditores. São exemplos, os programas Exonerate (Slater e Birney, 2005) e BLAT (Kent, 2002).

Há também a abordagem de predição que tenta unir os dois métodos. Essa abordagem, chamada de híbrida, incorpora alinhamentos para aumentar a precisão dos preditores ab initio. São exemplos dessa abordagem, o preditor Twinscan (Korf et al., 2001) que incorpora informações de alinhamento de sequências de espécies próximas e o preditor Augustus (Stanke et al., 2006) que incorpora sequências EST (Expressed Sequence Tag) e de proteínas para realizar a predição. Embora haja diferentes métodos de predição ab initio, todos os preditores disponíveis acoplam a modelagem probabilística ao código-fonte do preditor.

Dentro da Bioinformática, o campo de pesquisa de predição computacional de genes codificadores 
de proteínas não sofreu muitos avanços na última década. A última publicação de maior impacto foi a do preditor Augustus (Stanke et al., 2006). Acreditamos que esse pouco avanço nos últimos anos se dá porque tentar reconhecer a variabilidade dos genes por métodos computacionais envolve reconhecer os diferentes elementos que compõe a estrutura dos genes, a determinação precisa das fronteiras internas que separam esses elementos entre si e das fronteiras externas que delimitam os genes do restante do genoma. Essa tarefa é ainda um problema em aberto e exige do pesquisador o domínio de diferentes áreas como Estatística, Biologia Molecular e Computação.

O nosso grupo de pesquisa tem desenvolvido o MYOP (Make Your Own Predictor), um preditor de genes flexível, configurável e que facilita a construção e a experimentação de diferentes preditores. MYOP é o único preditor que consegue separar claramente a implementação do próprio preditor da implementação da arquitetura probabilística. Essa separação é possível, pois toda a construção e composição dos modelos probabilísticos é feita no ToPS (Toolkit of Probabilistic Models of Sequences). ToPS (Kashiwabara et al., 2013) é um arcabouço para manipulação de modelos probabilísticos que representam sequências de símbolos.

Resumidamente, o ToPS é o arcabouço probabilístico genérico e MYOP um cliente do ToPS que entende o problema de predição de genes. Desenvolvemos nesse trabalho uma metodologia que permite o MYOP utilizar informações extrínsecas (abordagem de predição híbrida) por meio da extensão dos algoritmos do ToPS usados no processo de predição. Implementamos duas técnicas conhecidas presentes nos preditores Augustus e Twinscan. Além disso desenvolvemos um Strategy (Gamma et al., 1995) que permite a separação das implementações das diferentes técnicas de predição híbrida do algoritmo de Viterbi GHMM presente no ToPS. Essa separação foi possível porque reunimos todas as informações de alinhamento numa matriz, chamada de matriz de contribuição extrínseca, e por meio dessa matriz podem ser combinadas as duas técnicas desenvolvidas e também novas técnicas que venham a ser desenvolvidas .

Os resultados obtidos da implementação da técnica Augustus mostraram que se as informações de alinhamento utilizadas forem conflitantes ou redundantes proporcionam uma diminuição da precisão do preditores que as utilizam como fonte de informações extrínsecas. Evidências de mapeamento sem indicação de regiões de UTR (3'ou 5') acabam por confundir os modelos, prejudicando ao invés de ajudar a predição do sítio de início de transcrição. Contudo, esperamos que no futuro nossa implementação mostre que o uso de informações de alinhamentos de alta confiabilidade melhora os resultados de predição ab initio.

Os resultados obtidos da implementação da técnica Twinscan, mostraram uma melhora 7\% nos resultados nas métricas de sensibilidade, precisão e f-score de stop códon; sem perdas ou ganhos nas outras regiões do gene, o que mostrou o potencial desta técnica em relação à anterior.

\subsection{Organização do texto}

No Capítulo 2, apresentamos conceitos essenciais de Biologia Molecular necessários para o entendimento do problema de predição de genes. No Capítulo 3, apresentamos as cadeias de Markov ocultas (HMM) e as cadeias de Markov generalizadas (GHMM), que são os principais modelos probabilísticos utilizados na construção de preditores de genes ab initio. No Capítulo 4, abordamos as diferentes estratégias utilizadas por diversos preditores no processo de reconhecimento de genes codificadores de proteínas. No Capítulo 5, focamos nos métodos de mapeamento realizados pelos 
preditores Augustus e Twinscan. No Capítulo 6, apresentamos a nossa solução de unificação de métodos de predição que utilizam informações de alinhamento e descrevemos as extensões implementadas no ToPS envolvidas na solução. No Capítulo 7, apresentamos o processo de validação da implementação assim como os resultados e comparações. No Capítulo 8, finalizamos o trabalho descrevendo as nossas conclusões e considerações finais. 


\section{Capítulo 2}

\section{Conceitos de Biologia Molecular}

Compreender os conceitos fundamentais da Biologia Molecular é crucial para o desenvolvimento de softwares com o intuito de auxiliar no conhecimento relativo às sequências genômicas. Em geral, esses softwares utilizam dados de regiões com sinais biológicos específicos presentes nas sequências genômicas para propor uma caracterização da estrutura dos genes codificadores de proteínas a partir de uma modelagem estatística. Nesse capítulo serão abordados os principais sinais biológicos e processos celulares que envolvem os genes codificadores de proteínas.

\subsection{Sequências biológicas}

Células são as unidades funcionais e estruturais de todos os organismos vivos (Lesk, 2014), desde os constituídos por apenas uma célula como a bactéria Escherichia coli ou pelos constituídos um número muito grade de células como o ser humano (Axelson-Fisk, 2015). Apesar da grande diferença entre os diversos organismos vivos, todos eles têm em comum diversos processos celulares e foram gerados a partir da divisão celular de uma única célula inicial. Células são pequenas unidades, delimitadas por membrana, preenchidas com uma solução aquosa concentrada de produtos químicos e dotadas de extraordinária habilidade de gerar cópias idênticas através do processo de replicação (Alberts et al., 2017).

De maneira geral, cada célula possui uma cópia completa de material genético que serve de guia para o funcionamento de um organismo, sendo uma versão deste material passada para seus descendentes (Axelson-Fisk, 2015). Esse material é composto por DNA, ácido desoxirribonucleico, um longo polímero não ramificado composto de duas longas cadeias formadas por quatro tipos de nucleotídeos. Nucleotídeos são monômeros, ou seja, pequenas moléculas orgânicas que se ligam umas as outras formando estruturas poliméricas mais complexas. Os nucleotídeos são formados por duas unidades básicas sendo uma comum a todos os nucleotídeos e a outra unidade variável: a unidade de um fosfato ligado a um açúcar (desoxirribose ou ribose) é comum a todos nucleotídeos e a unidade variável é formada por uma das quatro bases nitrogenadas (A, C, T e G: adenina, citosina, timina e guanina) que dá o nome ao nucleotídeo.

Os nucleotídeos de uma das cadeias simples de DNA estão ligados pelas suas unidades comuns, ou seja, o fosfato de um nucleotídeo está ligado ao açúcar do seguinte, enquanto que as bases dos nucleotídeos das duas cadeias distintas ligam-se por pontes de hidrogênio seguindo uma regra simples, porém rigorosa de complementariedade de bases: a base A liga-se com a $\mathrm{T}$ e a base $\mathrm{G}$ com a C. As ligações na cadeia simples são muito mais fortes do que as pontes de hidrogênio que ligam as 
fitas complementares e provocam o entrelaçamento das fitas formando uma espiral, a dupla-hélice de DNA. As duas cadeias complementares possuem direções opostas identificadas pela extremidade 5' e 3' do açúcar na unidade comum.

No interior da célula antes da divisão celular a qual uma célula-mãe se divide em duas célulasfilhas ocorre a replicação do DNA, um processo que a partir do DNA presente na célula-mãe (DNA molde) gera duas cópias idênticas do DNA da célula-mãe (Figura 2.1) e possibilita a herança de cada uma das cópias para uma célula-filha. Nesse processo, as pontes de hidrogênio do DNA da célula-mãe são quebradas e as duas fitas da dupla-hélice são desenroladas e separadas para que cada uma sirva de molde para a síntese de uma nova fita simples complementar. As duas novas fitas complementares são produzidas ao mesmo tempo na direção de síntese 5' para 3' e terão direções opostas em relação às suas fitas moldes, ou seja, a fita 5' 3' molde origina a fita 3' 5' filha e a fita 3' 5' molde origina a fita 5' 3' filha. Por exemplo uma fita molde ACTGG dará origem a uma fita complementar CCAGT. Ao final da replicação, o DNA de cada uma das células-filhas é híbrido, composto por uma cadeia de DNA molde da célula-mãe e uma nova cadeia complementar recém-sintetizada.

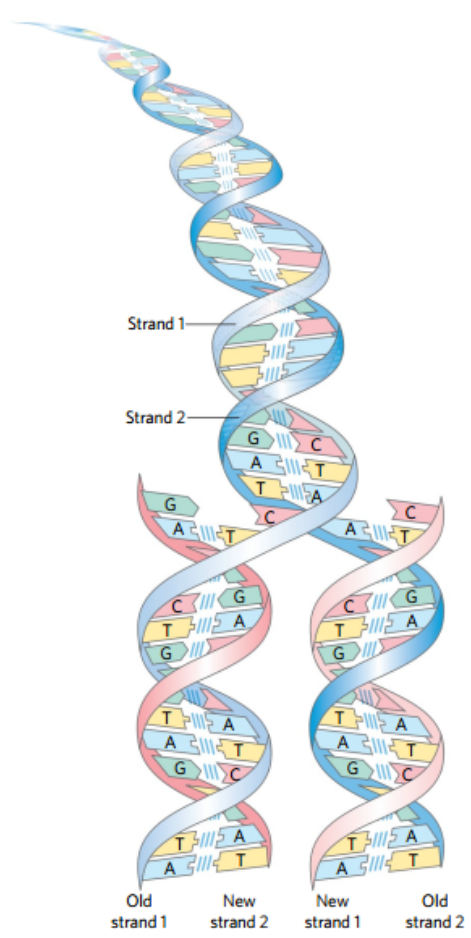

Figura 2.1: Fitas moldes parentais em azul e fitas recém-sintetizadas em rosa. Na replicação do DNA, as duas cadeias da dupla-hélice (em azul) se desenrolam e se separam para que duas novas cadeias (em rosa) sejam sintetizadas, cada uma com uma sequência complementar correspondente uma das cadeias parentais. O resultado da replicação são duas moléculas de dupla-hélice idênticas, cada uma constituída por uma cadeia que veio do DNA parental e outra cadeia recém-sintetizada (Lehninger et al., 2012).

O fluxo da informação genética de todas as células de qualquer ser vivo é de DNA para RNA (transcrição) e então RNA para proteína (tradução), uma regra tão universal que é denominada dogma central da biologia molecular (Figura 2.2). Contudo, embora universal, o dogma central sofreu ajustes em relação ao fluxo da informação com a descoberta do retrovírus e da enzima especial transcriptase reversa. Um retrovírus, como por exemplo o vírus da imunodeficiência humana (HIV) causador da AIDS, possui um genoma de RNA e pela ação da transcriptase reversa sintetiza 
DNA a partir do RNA viral (cadeia molde) dentro da célula infectada (Alberts et al., 2017). Na verdade existe um grande numero de categorias de RNAs que não são traduzidos que participam dos mecanismos de funcionamento celular, chamados de RNAs não codificantes (non-coding RNAs - ncRNAs) que, porém, não são objetos deste estudo.

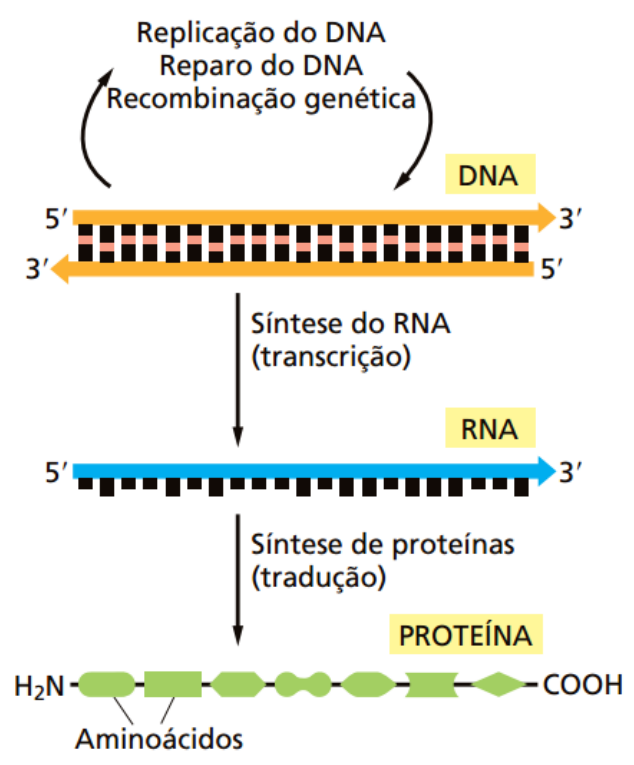

Figura 2.2: Dogma Central da Biologia Molecular, a via do DNA à proteína. O fluxo da informação genética do DNA ao RNA (transcrição) e do RNA à proteina (tradução) define a expressão gênica que ocorre em todas as células vivas. (Alberts et al., 2017).

\subsection{Transcrição e tradução}

O DNA é o repositório de informações genéticas de um organismo, esse repositório disponibiliza informações para diferentes células do organismo para que elas sintetizem outros tipos de polímeros conforme a necessidade. Além do DNA, dois outros polímeros são de grande relevância para todo o sistema de qualquer célula: o RNA e a proteína.

A transcrição é o processo de síntese de RNA (ácido ribonucleico): um polímero menor de nucleotídeos, de fita única e complementar a uma das cadeias do DNA. O RNA também é formado por nucleotídeos que possuem três unidades básicas: um fosfato, um açúcar (a ribose ao invés da desoxirribose) e a base nitrogenada. No entanto no RNA a base timina (T) é substituída por outra base, a uracila (U). Durante a transcrição um trecho de DNA é usado como molde e a polimerização (síntese) de RNA é feita por complementariedade de bases da cadeia simples de DNA e nova cadeia complementar de RNA que está sendo sintetizada de forma que a base A se liga com a U e a base C com a G.

Um dos significados de Transcrever é "escrever (algo escrito) em outro sistema ou em outro alfabeto" $^{1}$. No caso das sequências biológicas, a transcrição escreve do alfabeto de DNA (A, C, T, G) para o alfabeto de RNA (U, C, T, G). Além disso, um único trecho de DNA pode ser usado diversas vezes como molde para transcrições de sequências de RNA. Essas sequências de RNA transcritas funcionam como intermediários na transferência da informação genética. Mais

\footnotetext{
${ }^{1}$ dicionário de português Houaiss
} 
notavelmente, elas servem como moléculas de RNA mensageiro (mRNA) que guiam a síntese de proteínas.

A tradução é o processo de síntese de proteínas. O RNA transportador, tRNA, um pequeno RNA que possui em uma de suas extremidades um aminoácido e na outra um anticódon ${ }^{2}$, participa da tradução dentro do ribossomo (uma organela celular composta por proteínas e RNA ribossômico, rRNA). Durante a tradução três bases do tRNA (anticódon) ligam-se as três bases complementares do mRNA (códon) e a medida que os códons do mRNA vão sendo lidos pelo ribossomo, os aminoácidos são adicionados e ligados sequencialmente à cadeia de polipeptídeos da proteína conforme especificado no mRNA. Como há 64 códons $\left(4^{3}, 4\right.$ nucleotídeos possíveis para cada uma das três possíveis posições do códon) e apenas 20 aminoácidos diferentes, nota-se que essa correspondência é redundante, ou seja vários códons podem originar o mesmo aminoácido. Por exemplo, a Arginina (Arg) pode ser traduzida por qualquer um dos seguintes quatro códons CGU, CGC, CGA, CGG, AGA e AGG. O Código Genético (Figura 2.3) define as regras de associação de códons e aminoácidos. Embora universal, exceções a essas regras podem ser encontradas em bactérias; como a distribuição de códons de início da E. coli: 83\% AUG, 14\% GUG e 3\% UUG. (Blattner et al., 1997).

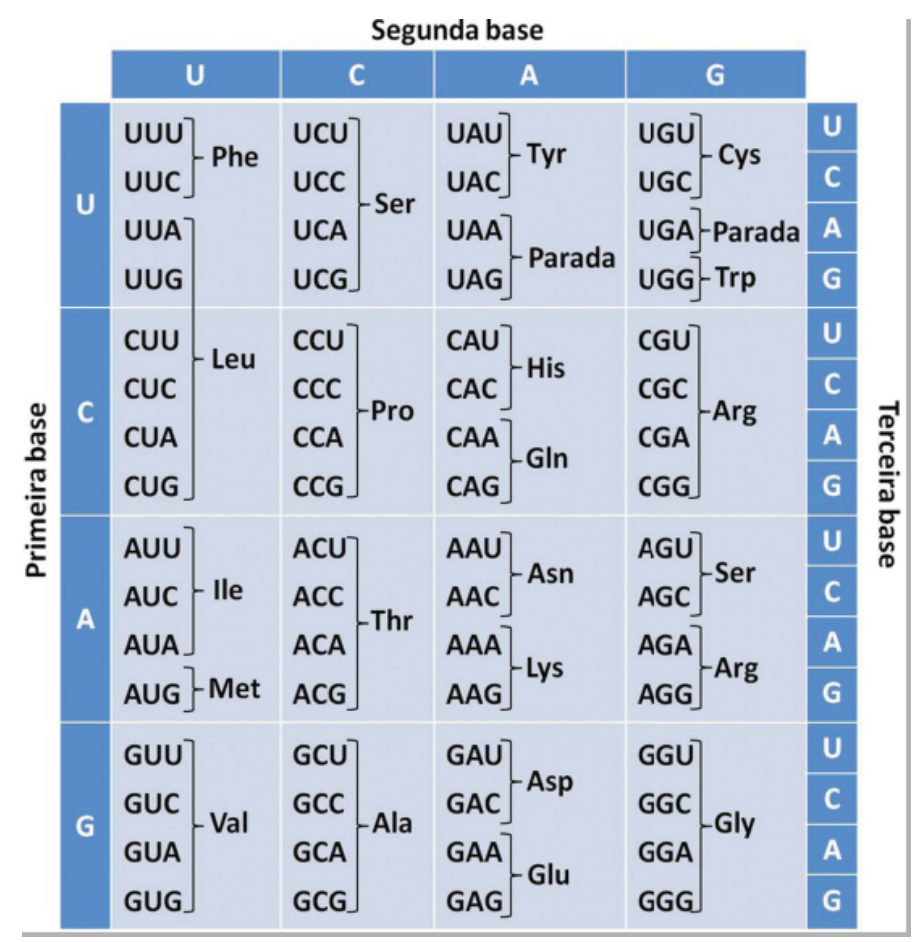

Figura 2.3: Código Genético (Moreira, 2015) que relaciona os códons do DNA e os aminoácidos da proteína.

\subsection{Genes codificadores de proteínas}

A sequência de DNA possui segmentos que indicam o início e o fim do mRNA transcrito. Diferentes regiões do DNA geram diferentes transcritos que por sua vez codificam para diferentes proteínas. Um gene é definido como um segmento da sequência de DNA correspondente a uma única proteína, ou grupo de variantes proteicas alternativas, ou uma única molécula de RNA catalítica, reguladora ou estrutural (Alberts et al., 2017). Assim, os genes podem ser divididos em genes

\footnotetext{
${ }^{2}$ um códon é uma trinca de nucleotídeos e um anticódon é uma trinca de nucleotídeos complementar a um códon
} 
codificadores de proteínas (Figuras 2.4 e 2.5) e genes não-codificadores de proteínas. Em geral, os genes não-codificadores de proteínas não possuem uma estrutura que o caracteriza, tal como a estrutura é encontrada nos genes codificadores. Por conta disso a predição dos genes não-codificadores torna-se uma tarefa ainda mais difícil e os preditores frequentemente acabam não os abordando e focam apenas nos genes codificadores de proteínas. No grupo do genes não codificadores de proteínas estão os que codificam o rRNA, o tRNA e o micro RNA (miRNA).

Enquanto o genoma é muito compacto em organismos mais simples como procariotos, com muito pouco material não funcional; em organismos mais complexos como humanos e ratos, os genes estão escondidos numa imensidão de DNA não codificador. Em humanos, por exemplo, menos de $2 \%$ do genoma codifica proteínas (Chin et al., 2006). Procariotos não possuem um envoltório nuclear para delimitar o núcleo do restante da célula, e com isso o seu material genético fica disperso no citoplasma onde ocorre a replicação, transcrição e tradução. Um mRNA bacteriano é organizado em anéis circulares e frequentemente pode ser policistrônico (poligênico). Um mRNA é policistrônico quando uma mesma região regulatória controla a codificação de um conjunto de genes, sendo esta região chamada de operon (Figura 2.4).

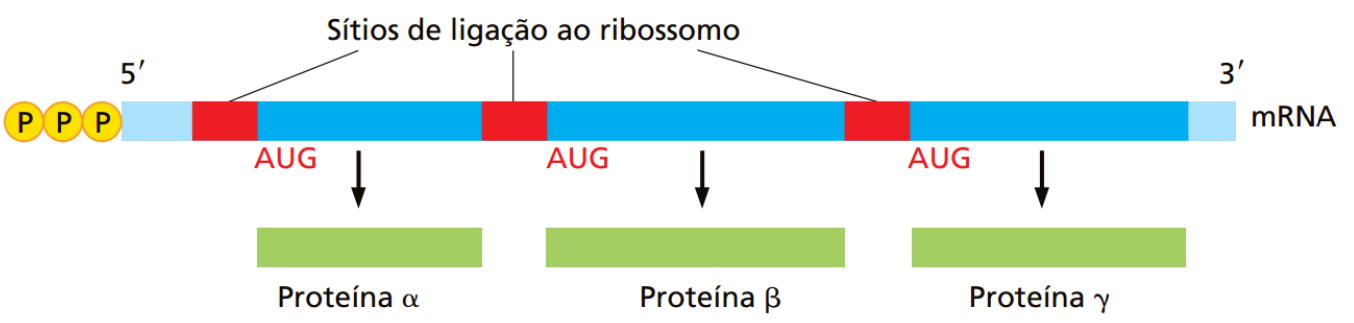

Figura 2.4: A estrutura de uma molécula típica de mRNA bacteriano. Os ribossomos procariotos iniciam a tradução em sítios de início (AUG) que podem estar localizados em qualquer lugar ao longo de uma molécula de mRNA. Isso permite que a sintetize de mais de um tipo de proteina a partir de uma única molécula de mRNA. (Alberts et al., 2017).

Embora sejam casos bem raros, operons já foram encontrados em eucariotos desde protozoários até cordados (Blumenthal, 2004). A estrutura típica de um gene eucarioto é formada por duas regiões não traduzidas que limitam o começo e o fim do gene (5'UTR e 3'UTR) e internamente contém regiões codificantes (éxons) e regiões não codificantes (íntrons). Na estrutura do gene eucarioto (Figura 2.5), há sinais biológicos bem conservados como os sítios de início de tradução (ATG) e de fim de tradução (TAA, TAG, TGA). 


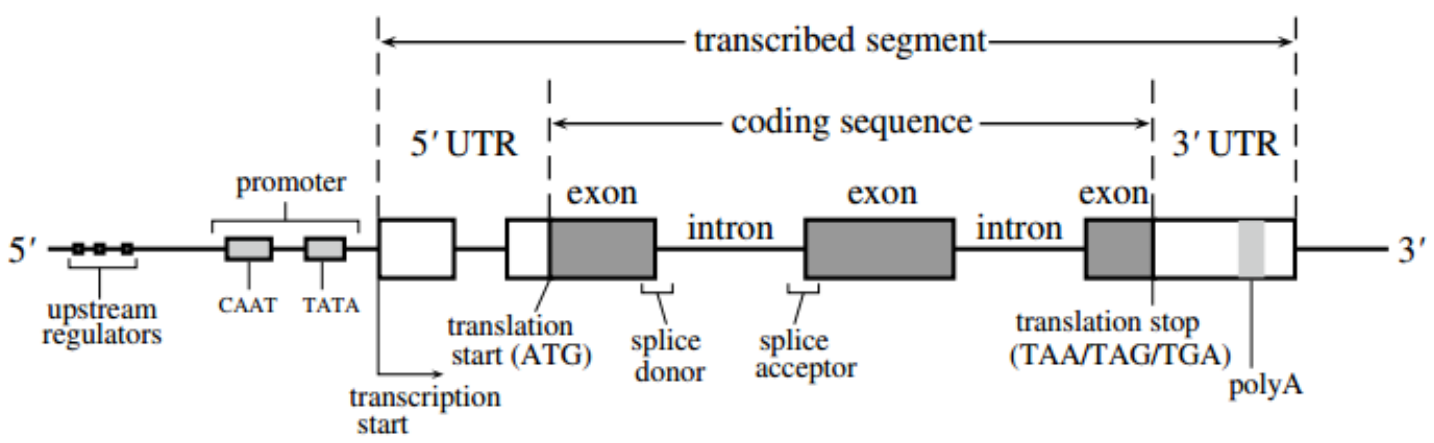

Figura 2.5: Fonte (Axelson-Fisk, 2015). A estrutura de um gene eucariótico. O gene é definido como o segmento que é transcrito em RNA. A sequência codificadora consiste de éxons que são traduzidos em aminoácidos e estão separados por introns que são removidos antes da tradução e que não codificam proteína. A região inicial do primeiro éxon e a região final do último éxon e as regiões 5'UTR e 3'UTR são regiões não traduzidas. As regiões 5'UTR e 3'UTR flanqueiam a sequência codificadora e não estão envolvidas na sintese de proteína. A região promotora contém sítios de ligação (tais como CAAT e TATA) para enzimas envolvidas na transcrição. As regiões que delimitam éxons e introns são chamadas de sítios doadores de intron (splice donor) que marcam o inicio de introns e sitios aceitares de intron (acceptor site) que marcam o fim de introns. Em geral, sítios doadores contém a sequência conservada GT e sítios aceitadores contém a sequência $A G$.

A expressão de um gene codificador de proteínas é o processo o qual a informação contida no gene é usada para sintetizar o mRNA e depois a proteína. Durante a etapa de transcrição é sintetizado um mRNA imaturo (pré-mRNA) que sofre algumas modificações para que se torne um mRNA (maduro). Essas modificações no pré-mRNA incluem o splicing que é a remoção dos íntrons e a ligação dos éxons, e a adição de um cap 5' (uma guanosina modificada na extremidade) no início e de uma cauda 3' poli-A (nucleotídeos A). Após essas modificações o mRNA pode ser usado na tradução.

No processo de splicing, além dos íntrons, alguns éxons também podem ser removidos e a ligação dos éxons remanescentes formam diferentes mRNAs originados do mesmo pré-mRNA. Esse processo é chamado de splicing alternativo (Figura 2.6) e como resultado diferentes mRNAs são traduzidos em proteínas diferentes. 


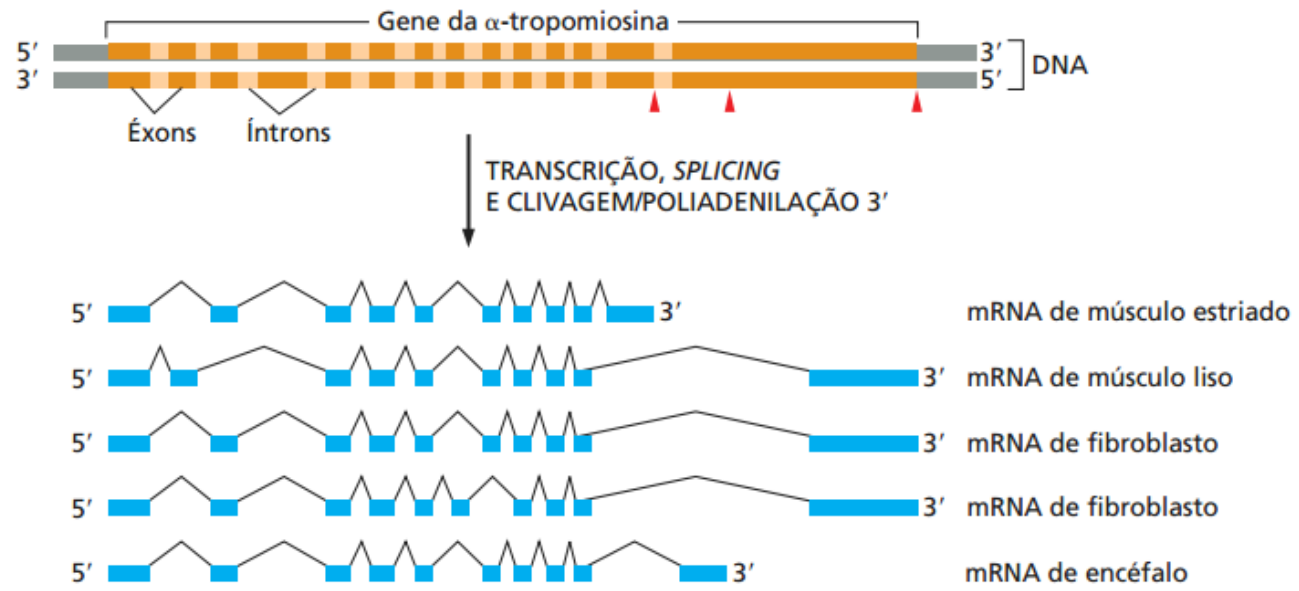

Figura 2.6: Um exemplo de splicing alternativo do pré-RNA de $\alpha$-tropomiosina. O transcrito primário de $\alpha$-tropomiosina pode ter seus introns retirados de 5 diferentes maneiras e produzir 5 mRNAs distintos: $m R N A$ de músculo estriado, mRNA de músculo liso, duas possibilidades de mRNAs de fibroblasto e $m R N A$ de encéfalo. Como resultado, mRNAs diferentes dão origem a proteinas diferentes. (Alberts et al., 2017) 


\section{Capítulo 3}

\section{Modelos Probabilísticos de Markov}

As cadeias de Markov, e mais especificamente os modelos ocultos de Markov generalizados são ferramentas muito importantes para a análise probabilística de sequências biológicas eucarióticas. Como visto no capítulo 2, a estrutura de um gene eucarioto consiste de regiões de éxons e íntrons e essas regiões são estatisticamente muito diferentes. Embora ainda seja muito difícil delimitar as bordas dessas regiões, os modelos ocultos de Markov Generalizadas são eficientes para encontrar essas diferentes partes da estrutura do gene e atribuir para cada uma o modelo probabilístico mais apropriado. Em predição de genes é comum que regiões de éxons não traduzidas não são sejam modeladas. Com isso, é usual, embora impreciso, o uso do termo éxon para designar, na verdade as regiões codificantes de proteína, ou CDS. No restante desta dissertação usaremos estes termos de maneira intercambiável, a não ser quando explicitamente indicado.

Neste capítulo descrevemos os modelos markovianos, visando apresentar o modelo oculto de Markov generalizado (Generalized Hidden Markov Model, GHMM) que é o modelo integrador utilizado nos preditores de genes híbridos abordados neste trabalho. A inclusão de informações de mapeamento é centrada na modificação do algoritmo de Viterbi, usado para rotulação de sequências de acordo com uma GHMM, o que torna importante a compreensão do modelo. Durante todo este capítulo utilizaremos a notação de Durbin et al. (1998).

\subsection{Cadeias de Markov}

Uma cadeia de Markov é um processo estocástico de uma variável aleatória $X$ que assume valores no tempo $t, X_{t}$, chamados de estados, com a seguinte propriedade (chamada propriedade markoviana): os valores $X_{s}$ para $s>t$ são independentes dos valores valores $X_{u}$ para $u<t$, ou seja, o valor da variável no presente $\left(X_{t}\right)$ depende somente do seu valor mais recente $\left(X_{t-1}\right)$, cuja formulação está definida na Equação 3.1.

$$
P\left(X_{t}=j \mid X_{0}=i_{0}, X_{1}=i_{1} \ldots, X_{t-1}=i_{t-1}, X_{t-1}=i\right)=P\left(X_{t}=j \mid X_{t-1}=i\right),
$$

para todo tempo $t$ e todos os estados $i_{0}, \ldots, i_{t-1}, i, j$ que $X_{t}$ assume. Essa dependência que a variável markoviana tem com seu valor mais recente é chamada de alcance ou memória da cadeia, nesse caso o alcance é igual a 1.

Cadeias de Markov são comumente representadas por um grafo dirigido no qual os vértices são chamados de estados, correspondendo a cada um dos possíveis valores da variável aleatória, e as 


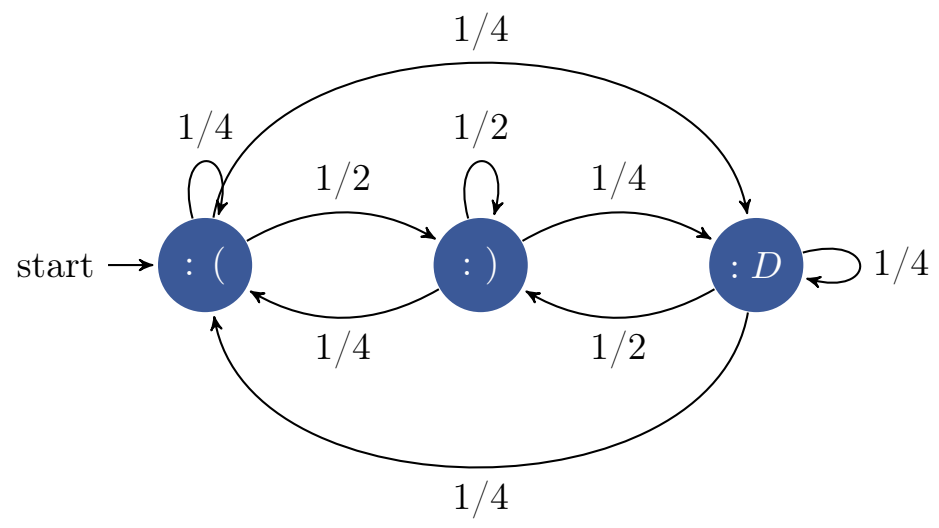

Figura 3.1: Uma cadeia de Markov para modelar três estados de uma pessoa durante seu dia: triste, feliz e muito feliz. A probabilidade de se iniciar em qualquer um dos três estados é a mesma, 1/3. Como as arestas que chegam no estado feliz possuem valores duas vezes maiores que as demais arestas, a pessoa modelada por essa cadeia de Markov tende a ficar no estado feliz mais tempo do que nos estados triste ou muito feliz.

arestas são as probabilidades de transição de um estado para outro. A Figura 3.1 apresenta um grafo para um exemplo simples de cadeia de Markov que modela o humor de uma pessoa durante o seu dia. As probabilidades de transição são dadas pela matriz $\mathrm{M}$, onde $a_{i j}$ é a probabilidade de transição do estado $i$ para o estado $j$ sendo que i e $\mathrm{j}$ assumem os valores 1,2 e 3 indicando os humores triste, feliz e muito feliz respectivamente. No restante deste texto usaremos os termos estado e valor da variável aleatória como sinônimos.

$$
\begin{gathered}
a_{i j}=P\left(X_{t}=j \mid X_{t-1}=i\right) \\
M=\left(\begin{array}{lll}
a_{11} & a_{12} & a_{13} \\
a_{21} & a_{22} & a_{23} \\
a_{31} & a_{32} & a_{33}
\end{array}\right)=\left(\begin{array}{ccc}
1 / 4 & 1 / 2 & 1 / 4 \\
1 / 4 & 1 / 2 & 1 / 4 \\
1 / 4 & 1 / 2 & 1 / 4
\end{array}\right)
\end{gathered}
$$

Para este exemplo determinamos que a probabilidade de se iniciar a sequência de valores no estado $i \in 1,2,3$ é:

$$
\begin{gathered}
a_{01}=1, a_{02}=a_{03}=0 \\
P\left(x_{1}=1\right)=1, P\left(x_{1}=2\right)=P\left(x_{1}=3\right)=0
\end{gathered}
$$

A probabilidade de uma sequência de estados $P(x)$, onde $x=x_{1} x_{2} \ldots x_{L}$, sendo cada $x_{i}$ um valor (ou símbolo) que uma variável aleatória markoviana $X_{i}$ é dada pela equação:

$$
\begin{aligned}
P(x) & =P\left(x_{1} x_{2} \ldots x_{L}\right) \\
& =P\left(x_{L} \mid x_{L-1}, \ldots x_{1}\right) P\left(x_{L}-1 \mid x_{L-2}, \ldots x_{1}\right) P\left(x_{L}-2 \mid x_{L-3}, \ldots x_{1}\right) \ldots P\left(x_{1}\right) \\
& =P\left(x_{L} \mid x_{L-1}\right) P\left(x_{L-1} \mid x_{L-2}\right) P\left(x_{L-2} \mid x_{L-3}\right) \ldots P\left(x_{1}\right) \\
& =a_{x_{L-1} x_{L}} a_{x_{L-2} x_{L-1}} a_{x_{L-3} x_{L-2} \ldots P\left(x_{1}\right)} \\
& =P\left(x_{1}\right) \prod_{i=2}^{L} a_{x_{i-1} x_{i}} .
\end{aligned}
$$

Com a Equação 3.3 e o modelo da Figura 3.1 podemos calcular, por exemplo, a probabilidade 
de uma pessoa durante o dia passar pelo estado feliz três vezes e depois pelo estado muito feliz uma vez, dado que essa pessoa não acordou muito bem, foi ao médico e iniciou o dia no estado triste.

Relembrando que os estados 1, 2 e 3 na matriz $M$ são os estados triste, feliz e muito feliz respectivamente. Assim $x=[1,2,2,2,3]$ e $\mathrm{P}(\mathrm{x})$ :

$$
\begin{aligned}
P(x) & =P\left(x_{1}\right) \prod_{i=2}^{L} a_{x_{i-1} x_{i}}=P\left(x_{1}\right) \prod_{i=2}^{5} a_{x_{i-1} x_{i}} \\
& =P(1) a_{12} a_{22} a_{22} a_{23}=1 \times 1 / 2 \times 1 / 2 \times 1 / 2 \times 1 / 4=1 / 32 .
\end{aligned}
$$

Em cadeias de Markov há duas restrições intrínsecas:

1. uma relação "um para um" entre o estado e o valor que variável aleatória assume (símbolo observado), ou seja, um símbolo é emitido por somente um estado. Desse modo, a sequência de símbolos observáveis é igual a sequência de estados percorridos pela cadeia de Markov para gerar a sequência de símbolos.

2. um estado emite um e somente um símbolo, ou seja, a cadeia de Markov fica um tempo $t=1$ num estado, emite um símbolo e já transita para outro estado sucessor que pode ser o mesmo estado.

Os Modelos Ocultos de Markov e Modelos Ocultos de Markov Generalizados resultam de modificações nestas propriedades. O relaxamento da primeira restrição dá origem Modelos Ocultos de Markov (HMM, Hidden Markov Model) e o relaxamento de ambas restrições anteriores dá origem aos Modelos Ocultos de Markov Generalizadas (GHMM, Generalized Hidden Markov Model). Esses dois modelos serão descritos nas próximas seções.

\subsection{Modelos Ocultos de Markov - HMM}

Como dito anteriormente, na HMM não há a restrição "um para um" entre estado e símbolo emitido por ele emitido. Por isso para definir uma HMM um novo parâmetro que une símbolo e estado é necessário. Seja $e_{k}(b)$ a probabilidade de emissão de um símbolo $b$ pelo estado $k, X=$ $x_{1}, \ldots x_{i} \ldots, x_{L}$ o processo observável e $\Pi=\pi_{1}, \ldots \pi_{i}, \ldots, \pi_{L}$ o processo oculto de estados percorrido pela HMM. A relação entre esses três valores é dada pela equação:

$$
e_{k}(b)=P\left(x_{i}=b \mid \pi_{i}=k\right) .
$$

As probabilidades de transição da HMM determinam o processo oculto de sequência (ou caminho) de estados e é definida de uma forma semelhante à probabilidade de transição de uma cadeia de Markov (Equação 3.2). Seja $a_{k l}$ da probabilidade de transição do estado $k$ para o estado $l$ e $\pi_{i}$ o i-ésimo estado do caminho $\Pi=\pi_{1} \pi_{2} \pi_{3} \ldots \pi_{L}$ de tamanho $L$ :

$$
a_{k l}=P\left(\pi_{i}=l \mid \pi_{i-1}=k\right) .
$$

A partir das equações 3.5 e 3.4, a probabilidade conjunta $P(X, \Pi)$ da sequência de símbolos observáveis $X$ e da sequência de estados $\Pi$ de uma HMM é: 


$$
P(X, \Pi)=a_{0 \pi_{1}} \prod_{i=1}^{L} e_{\pi_{i}}\left(x_{i}\right) a_{\pi_{i} \pi_{i+1}},
$$

onde $a_{0 \pi_{1}}=P\left(\pi_{1}=s_{j}\right)$ é a probabilidade do primeiro estado do caminho ser $s_{j}, 1 \leq j \leq N$, com $N$ o número de estados da HMM e $a_{\pi_{L} \pi_{L+1}}=1$ a última transição para modelar o fim da sequência.

A principal consequência do relaxamento da restrição "um para um"que caracteriza uma HMM é a que uma sequência de observação $X$ pode ser gerada por muitas sequências distintas de estados. Rabiner (1989) definiu três problemas básicos relacionados aos HMMs:

- Problema da Decodificação: encontrar a sequência de estados ou caminho $\pi_{1} \pi_{2} \pi_{3} \ldots \pi_{L}$ que deu origem uma sequência de observação $x_{1} x_{2} x_{3} \ldots x_{L}$ segundo algum critério. O exemplo a seguir é um problema de decodificação cujo critério utilizado foi a escolha do caminho $\pi^{*}$ de maior probabilidade conjunta $P(X, \Pi)$ :

$$
\Pi^{*}=\underset{\Pi}{\arg \max } P(X, \Pi) .
$$

- Problema do Treinamento: visa encontrar o conjunto de parâmetros $a_{k l}$ e $e_{k}(b)$ do modelo HMM $\lambda$ que maximize a probabilidade conjunta de todas as $n$ sequências do conjunto de treinamento, $P\left(X^{1}, X^{2}, X^{3} \ldots X^{n} \mid \lambda\right)$.

- Problema da Avaliação: visa encontrar a probabilidade de gerar uma sequência $X$ dado um modelo HMM $\lambda, P(X \mid \lambda)$.

Discorreremos sobre os três problemas estendendo o exemplo da Figura 3.1. A Figura 3.2 mostra uma HMM com dois estados para modelar o humor de um paciente fictício deprimido. O estado cinza (humor deprimido) tem as probabilidades de emissão e transição de um paciente deprimido e outro estado azul tem as probabilidades de um paciente normal ou não deprimido. Como os dois estados emitem os mesmos símbolos, variando as distribuições de probabilidade, não é possível identificar a partir da sequência de símbolos emitida qual é a sequência de estados que a originou. Encontrar esses estados é o Problema da Decodificação.

Sejam $t, f, m$ os símbolos usados para representar as observações triste, feliz e muito feliz (respectivamente), descrevendo a condição do paciente registradas em cada momento pelo médico. Suponha que o médico suspeite que o paciente esteve deprimido no período registrado. Para avaliar a sua suspeita ele observa o paciente e anota o seu estado como triste, feliz e triste durante três dias. O médico deseja saber se a suposta melhora no segundo dia (observação feliz) indica que o paciente não estava deprimido nesse dia. 


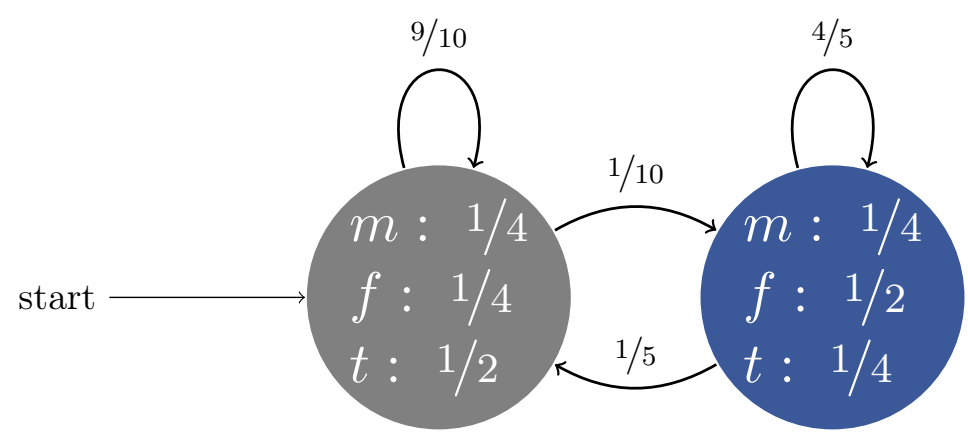

Figura 3.2: HMM para modelar uma pessoa fictícia depressiva. Seja $t, f, m$ símbolos que denominam triste, feliz, e muito feliz. O estado de depressão (em cinza, é representado por d em $e_{d}\left(X_{i}\right)$ ) possui a probabilidade de emissão do símbolo triste $e_{d}(t)=1 / 2$ e a probabilidade dos símbolos de feliz e muito feliz $e_{d}(f)=e_{d}(m)$ $=1 / 4$. Além disso, a HMM inicia no estado de depressão e a sua aresta de auto-transição é $9 / 10$ conduzindo a HMM continuar nesse estado e emitir mais símbolos de tristeza modelando a dificuldade encontrada por pessoas com depressão a sair desse estado.

Seja $X=\left\{x_{i} \mid 1 \leq x_{i} \leq L, x_{i} \in\{t, f, t\}\right\}$ a sequência de símbolos referente as três observações realizadas pelo médico, e seja $d$ o estado deprimido e $n$ o estado normal. Não é possível saber a sequência de estados $\Pi$ que deu origem a $X$, ou melhor, não é possível saber o estado do paciente (se está deprimido ou normal) em cada dia observando a sua condição aparente nesses três dias. Dessa forma, para saber o estado $d$ da segunda observação $x_{2}$, podemos listar todas as sequências de estado possíveis $\pi_{i}(1 \leq i \leq 8)$, calcular as suas probabilidades conjuntas $P\left(\Pi^{k}, X\right)$ usando a equação 3.6 e encontrar o $\Pi^{*}$ como $\pi_{i}$ mais provável, ou seja, o $\Pi^{k}$ que torne $P\left(\Pi^{k}, X\right)$ máxima.

- $\Pi^{i}=(d, d, d)$

$$
\begin{aligned}
P\left(\Pi^{1}, X\right) & =a_{0 d} \times e_{d}(t) a_{d d} \times e_{d}(f) a_{d d} \times e_{d}(t) a_{d(L+1)} \\
& =1 \times(1 / 2 \times 9 / 10) \times(1 / 4 \times 9 / 10) \times(1 / 2 \times 1) \approx 0,51
\end{aligned}
$$

- $\Pi^{2}=(d, d, n)$

$$
\begin{aligned}
P\left(\Pi^{2}, X\right) & =a_{0 d} \times e_{d}(t) a_{d d} \times e_{d}(f) a_{d n} \times e_{n}(t) a_{d(L+1)} \\
& =1 \times(1 / 2 \times 9 / 10) \times(1 / 4 \times 1 / 10) \times(1 / 4 \times 1) \approx 0,0056
\end{aligned}
$$

- $\Pi^{3}=(d, n, d)$

$$
\begin{aligned}
P\left(\Pi^{3}, X\right) & =a_{0 d} \times e_{d}(t) a_{d n} \times e_{n}(f) a_{n d} \times e_{d}(t) a_{d(L+1)} \\
& =1 \times(1 / 2 \times 1 / 10) \times(1 / 2 \times 1 / 5) \times(1 / 2 \times 1)=0,0025
\end{aligned}
$$

- $\Pi^{4}=(d, n, n)$

$$
\begin{aligned}
P\left(\Pi^{4}, X\right) & =a_{0 d} \times e_{d}(t) a_{d n} \times e_{n}(f) a_{n n} \times e_{n}(t) a_{d(L+1)} \\
& =1 \times(1 / 2 \times 1 / 10) \times(1 / 2 \times 4 / 5) \times(1 / 4 \times 1)=0,005
\end{aligned}
$$

- $\Pi^{5}=(n, n, n), \Pi^{6}=(n, n, d), \Pi^{7}=(n, d, n)$ е $\Pi^{8}=(n, n, n)$

$$
P\left(\Pi^{5}, X\right)=P\left(\Pi^{6}, X\right)=P\left(\Pi^{7}, X\right)=P\left(\Pi^{8}, X\right)=0 .
$$

pois $a_{0 n}=0$, uma vez que a HMM sempre começa no estado $d$ (Figura 3.2). 
Dessa forma temos que $\Pi^{*}=(d, d, d)$ e com isso, embora a segunda observação feita pelo médico seja $f$ ( $f e l i z)$, é mais provável que o paciente estava deprimido naquela observação, pois o estado correspondente no caminho mais provável é $d$ dada a HMM da Figura 3.2,

$\mathrm{Na}$ prática, identificar a sequência de estados a partir da sequência de símbolos por "força bruta", como foi feito anteriormente, é impraticável para sequências grandes como as sequências genômicas, uma vez que o número de possíveis caminhos $c$ cresce exponencialmente em função do tamanho da sequência $l$ e do número de estados $e$. No exemplo anterior, com temos apenas 2 estados $(N=2)$ e três observações, temos:

$$
c=N^{L}=2^{3}=8 \text { caminhos }
$$

Para o cálculo eficiente da rotulação de maior probabilidade utilizamos o Algoritmo de Viterbi.

Em nosso exemplo hipotético, o Problema do Treinamento envolve estimar as probabilidades de observação (triste, feliz e muito feliz) e as probabilidades de transição de cada estado (normal e depressivo) e compor estrutura da HMM. O médico poderia realizar essa estimação acompanhando dia a dia seus pacientes com depressão e sem depressão (normal) e usar as frequências de observações e as frequências de transições de estados dos seus pacientes como os valores de probabilidade de emissão e transição.

No processo de predição de genes, o Problema do Treinamento é geralmente atacado dependendo do conjunto de treinamento. Caso o conjunto de treinamento seja composto por sequências conhecidas, ou seja sequências anotadas (suas decodificações são conhecidas), é usada a estimação por máxima verossimilhança. Na ausência de um conjunto de treinamento com rotulação conhecida pode-se utilizar uma outra abordagem, o algoritmo de Baum-Welch, Porém este algoritmo não será abordado nesta dissertação, uma vez que, tanto quanto nossa pesquisa revelou, não existe uma formalização do treinamento Baum-Welch com inclusão de dados de mapeamento.

O Problema da Avaliação envolve calcular a probabilidade de uma sequência determinada ser gerada por um modelo probabilístico. Ele é usado em classificação de sequências, mas não no problema de rotulação e, assim, não será descrito neste trabalho.

\subsubsection{Algoritmo de Viterbi HMM}

Boa parte dos preditores, em particular Augustus e Twinscan, relevantes para este trabalho, utilizam GHMMs para modelagem da estrutura do gene e o algoritmo de Viterbi para realizar a rotulação. No restante desse Capítulo vamos dar maiores detalhes a respeito dos algoritmos Viterbi HMM e Viterbi GHMM e no Capítulo 6 apresentamos como modificamos o algoritmo de Viterbi da GHMM do ToPS para lidar com dados de alinhamento.

Como dito anteriormente, encontrar o caminho mais provável (decodificação) da sequência por força bruta é impraticável para sequências grandes. O algoritmo de Viterbi é um algoritmo baseado em programação dinâmica que realiza a decodificação em $O\left(L N^{2}\right)$, onde $L$ é o tamanho da sequência a ser decodificada e $N$ o número de estados da HMM. A complexidade de tempo do algoritmo de Viterbi é $O\left(L N^{2}\right)$, pois para cada posição da sequência de tamanho $L$ são analisados todos os $N$ estados e a análise de cada estado envolve a avaliação de seus estados vizinhos para a posição anterior. Como no pior caso, um estado é vizinho de todos os outros temos $O(L N N)=O\left(L N^{2}\right)$. Embora essa seja a complexidade, o algoritmo de Viterbi HMM pode ser implementado com al- 
gumas otimizações que tornam sua complexidade $O(L N C)$, onde $C \leq N$ é a cardinalidade de estados anteriores (número de vizinhos com arestas para o estado em questão) do estado com maior cardinalidade.

O algoritmo de Viterbi utiliza uma matriz, chamada de matriz de Viterbi, que armazena os valores da variável $v_{k}(i)$ que é o valor da probabilidade do caminho mais provável que termina no estado $k$ com a observação do i-ésimo símbolo da sequência. Essa matriz é formada por $N$ linhas e $L$ colunas. A partir da hipótese de que todas as $v_{k}(i)$ até a posição $i$ já foram calculadas e armazenadas na matriz, a variável $v_{l}(i+1)$ para qualquer estado $l$ da HMM é calculada com seguinte recursão:

$$
v_{l}(i+1)=e_{l}\left(x_{i+1}\right) \max _{k}\left(v_{k}(i) a_{k l}\right) .
$$

A medida que a matriz de Viterbi, é preenchida também necessário preencher outra matriz $\operatorname{ptr}_{l}(i)$ que registra o valor $k$ escolhido pela equação anterior:

$$
\operatorname{ptr}_{l}(i+1)=\underset{k}{\operatorname{argmax}}\left(v_{k}(i) a_{k l}\right) .
$$

Com a matriz $\operatorname{ptr}_{l}(i)$ concluída, é realizado o traceback (rastreamento do fim da matriz para o começo da sequência) a fim de encontrar o caminho mais provável.

\subsection{Modelos Ocultos de Markov Generalizados - GHMM}

No processo de predição de genes são utilizados diversos modelos probabilísticos individuais para descrever os sinais biológicos presentes na estrutura do gene. Um modelo probabilístico para predição de genes basicamente consiste num modelo principal integrador que serve de base para representar a estrutura completa do gene e de submodelos específicos que representam cada uma das diferentes partes do gene (Figura 2.5). A GHMM é modelo integrador mais empregado na construção de preditores de genes.

A segunda restrição intrínseca de Cadeias de Markov, que determina que um estado emite um e somente um símbolo por transição, significa que a probabilidade de um estado $k$ rotular $M$ símbolos consecutivos, modelada pelo uso de uma aresta de autotransição, tenha um decaimento exponencial $\left(P_{k}(M)=\left(a_{k k}\right)^{M-1}\left(1-a_{k k}\right)\right)$. Essa distribuição de tamanhos não é adequada para modelar trechos de sequências genômicas como éxons e íntrons. Por exemplo, no genoma humano cerca de $80 \%$ dos éxons em cada cromossomo têm menos de 200 pares de bases de comprimento, 0,01\% dos íntrons têm menos que 20 pares de bases e menos de $10 \%$ dos íntrons têm mais de 11000 pares de base de comprimento (Sakharkar et al., 2004).

GHMMs são variantes de HMMs que permitem modelar, para cada estado, as distribuições de probabilidade de emissão de símbolos e de probabilidade de duração (permanência) no estado com quaisquer modelos probabilísticos, permitindo distribuições sem decaimento exponencial para o número de símbolos adjacentes modelados pelo mesmo estado. Por isso, está variante é muito mais adequada para enfrentar problemas de distribuição de tamanhos de íntrons e de éxons como o problema visto anteriormente.

Assim como foi feito para HMM definindo o parâmetro $e_{k}\left(x_{i}\right)$ para emissão, é preciso definir um novo parâmetro que une estado e quantidade de símbolos emitidos por esse estado. Seja $f_{k}(d)$ a função de distribuição de probabilidades dos tamanhos $d$ de símbolos emitidos pelo estado $k$, 
sendo $d \in D_{k}$, onde $D_{k}$ é o conjunto de durações possíveis do estado $k$. Importante lembrar que, como $f_{k}(d)$ é uma função de distribuição de probabilidade, a soma das probabilidades de todas as durações $d \in D_{k}$ é igual a 1 :

$$
\sum_{d \in D_{k}} f_{k}(d)=1
$$

Precisamos agora modificar o parâmetro $e_{k}\left(x_{i}\right)$ para $e_{k}\left(x_{i-d+1}^{i}\right)$, visando caracterizar a probabilidade de emissão de uma subsequência de $x$ de tamanho $d$.

\subsubsection{Algoritmo de Viterbi GHMM}

Essencialmente, o algoritmo de Viterbi GHMM é um ajuste do algoritmo de Viterbi HMM para levar em consideração a distribuição de tamanhos $f_{k}(d)$ e probabilidade de emissão $e_{k}\left(x_{i-d+1}^{i}\right)$ de um trecho de tamanho $d$ da sequência. Esses novos parâmetros são usados para compor a variável Viterbi $v_{k}(i)$ de todos os estados $k$ e da GHMM.

O algoritmo de Viterbi GHMM é um algoritmo também baseado em programação dinâmica que realiza a decodificação em $O\left(L^{2} N^{2}\right)$, onde $L$ é o tamanho da sequência a ser decodificada e $N$ o número de estados da GHMM. A complexidade de tempo do algoritmo de Viterbi é $O\left(L^{2} N^{2}\right)$, pois para cada posição da sequência de tamanho $L$ são analisados todos os $N$ estados e cada estado também avalia, para cada possível duração, todos os estados anteriores (backtracking), o que, no máximo, são $L$ vizinhos. Assim temos a complexidade, no pior caso $O(L N N L)=O\left(L^{2} N^{2}\right)$.

Os estados da GHMM são geralmente divididos em dois grupos: estados com duração fixa e estados com duração explícita. Os estados com duração fixa são estados cujas durações são sempre um valor constante e, nestes casos não é necessário o backtracking. Os estados de duração explícita são estados cujas durações são valores $d$ cuja distribuição segue um modelo probabilístico. Se houver um limite $E$ para o valor $d$ das distribuições $f_{k}(d), F$ estados com duração fixa e um limite $C$ de estados anteriores, como visto na caracterização de HMMs, a complexidade do algoritmo Viterbi GHMM é reduzida de $O\left(L^{2} N^{2}\right)$ para $O(L((N-F) E C+F C))$.

Assim como o algoritmo Viterbi HMM, o algoritmo Viterbi GHMM também utiliza a técnica de programação dinâmica para armazenar $v_{k}(i)$ numa matriz e calcular cada $v_{l}(i+1)$ a partir da mesma hipótese de que todas as $v_{k}(i)$ anteriores já foram calculadas e armazenadas nessa matriz. A variável $v_{k}(i)$ para todo estado $k$ da GHMM e posição $i$ da sequência é calculada com seguinte recursão:

$$
v_{l}(i+1)=\max _{k, d} v_{k}(i-d) a_{k l} f_{l}(d) e_{l}\left(x_{i-d+1}^{i}\right)
$$

A medida que a matriz de Viterbi é preenchida, além de ser necessário preencher a matriz $\operatorname{ptr}_{l}(i)$ com o estado $k$ anterior ao estado $l$ na posição $i$ com é feito no algoritmo Viterbi HMM, também é preciso armazenar outra matriz, a matriz $d t_{l}(i)$, com a duração $k$ utilizada na fórmula anterior para o estado $l$ na posição $i$.

$$
\begin{gathered}
\operatorname{pr}_{l}(i+1)=\underset{k}{\operatorname{argmax}}\left(v_{k}(i) a_{k l}\right), \\
d \operatorname{tr}_{l}(i+1)=\underset{k}{\operatorname{duration}}\left(v_{k}(i) a_{k l}\right) .
\end{gathered}
$$




\section{Capítulo 4}

\section{Predição de genes}

O objetivo da predição de genes é encontrar a localização das diferentes partes que compõe a estrutura do gene. Genes que não codificam proteínas (genes não codificantes) não possuem estruturas conservadas (Figuras 2.4 e 2.5) e por isso é comum que os preditores ignorem os genes não codificadores e foquem seus esforços nos genes codificadores (Axelson-Fisk, 2015).

As metodologias (in silico) aplicadas nos preditores buscam construir programas que reconheçam sítios conservados presentes nos elementos que compõe a estrutura dos genes. Na Figura 4.1 estão destacados alguns desses elementos como códon de início ATG (em roxo), códon de fim TAG (em roxo), éxons (em vermelho), íntrons (regiões entre os éxons), sítios de íntrons que flanqueiam éxons (sublinhados) e um potencial sítio de poliadenilação (em azul sublinhado).

\begin{tabular}{|c|c|}
\hline GACAGTTATATATCTAGTATCTAACAGAACCCTACCTGGACACAATCTTCTGAGTCTCAG & -333 \\
\hline TCTCAGACGAGTTATAAGGTAGTCTCATCTGGCAGAGGCTATGATTTGTTGTTTAACCTA & -273 \\
\hline ССТСAATCTTCCACCCTTGACTCTATCCTTCTATGCAATCTCTCAATCAGGGCTGGCTGA & -213 \\
\hline САCAGAGCTTTTCTTTCTTTTTTCTTTTTCTTTCTTTATAAACACCGATCGTGGTACTCG & -153 \\
\hline TCCTCCAAAGTGTCAGTCAAACTCATCTACTGATTCATCCTGTGGTACGATATCTAACAT & -93 \\
\hline CAATCTGTTCTTTTTATTCCATGAATGATGAAATCGTTTAGTRAACATTCATAAAAGCAT & -33 \\
\hline ATTTATTTAATAATAATAAGACTCTTTTCATCATGAGAGAAATTGTGTAAGTGTTCCACT & 28 \\
\hline AAGACTTAAACCCGATCATTTTTATCCAGAACAAGAACAGTTACAGTGGAGCAGGATCTG & 88 \\
\hline GTCAAATTGTTCATGTTTTTTGTTTTTTGTTTTAAAAAATGATCGAAACAGTCATCTTCA & 148 \\
\hline GACTGGTCAAGTAAGTCTATTTTTCTTGTTCTTTGCAATACTTCTTAAATAGTTGATCTG & 208 \\
\hline ACGTCAGGAACTGTATCTGTCAMTAGTGTGGTAACCAAATCGGTATGTGGGAAGCACCTT & 268 \\
\hline GAAGTTTAGATTTAAATATGCTATGGAGTGCTGCACTAACGGTCAACTTTCATTYCTCTC & 328 \\
\hline GATCACAGGTGCCAAGTTCTGGGAAGTTGTCTGTGATGAGCATGGAATCGCTACTGACGG & 388 \\
\hline ACAGTGAGTGATCTGAAGCTTTTTTTTATTTTTTATTTTTATTTTATTTTTTTTACTGAT & 448 \\
\hline ATCCTCTGAGACCGTCTAAATCATCAATTGTTTCATCTCGATCAGGTACAAGGGAACAAC & 508 \\
\hline CGATCTTCAACTGGAAAGAATCAGTGTTTACTACGTAAGGCCAGATTACTTCTTCATACA & 568 \\
\hline CGCCCATGGGGCATTTCAATTTATGGCTTTTTTCTTGAAAAAAAGTTTCATTAACTAACT & 628 \\
\hline TTGAGTTTAAAAATAGAATGGATGAAATGGAATTCACAGAGGCTGAGTCCAACGTGCAAG & 688 \\
\hline ATCTGATTGCAGAATACCAGCAATACCAGGAAGCTCATATGGAGGAGGAAGATGGTGATG & 748 \\
\hline AGGTTTATGAGGATGAGGTATGTTTTTAGACAAAAATTACATGAAAATATATCTACTAAT & 808 \\
\hline AATTGAAGCTTTTTTGGCTTGGTCACTTATTTATCTATTCTTCCATTAACTCCTTCCATT & 868 \\
\hline TTTATTGTGTTAAAACCAAAAATAGCCCCTTCCAGAAGAGTAGAAGCTGAATCTGGAATT & 928 \\
\hline AGAGTTGTGAGAATCATGGTAAAGGAGAATAAATAATAATCATAAAAAAATCTTTACAAA & 988 \\
\hline ATTTTGATGCAATAGTACTTTTTTTAATCATTTTTATTTATTTTTTTTTAAAAAAAAATT & 1048 \\
\hline
\end{tabular}

Figura 4.1: Sítios gênicos conservados (Moreira, 2015).

A predição de genes codificadores de proteínas é geralmente mais fácil em organismos procariotos do que em organismos eucariotos. Em procariotos, como por exemplo o organismo modelo $E$. 
Coli, vários padrões de sequência altamente conservados são encontrados na região promotora e em torno dos sítios iniciais de transcrição e tradução (Gollery, 2005). O genoma desses organismos normalmente são menores do que os de eucariotos e é formado por um único cromossomo circular cujo conteúdo é em maior parte região codificante de proteínas. Mais importante, a região codificadora não é interrompida por íntrons. Essa menor complexidade explica parcialmente porque temos na literatura bons resultados publicados para genomas procariotos, como listado por Angelova et al. (2010).

Genes eucariotos possuem uma estrutura mais complexa do que os de procariotos e prever essa estrutura corretamente é uma tarefa mais difícil devido a própria natureza fragmentada dessa estrutura que apresenta éxons normalmente pequenos e íntrons normalmente grandes. As predições em genomas eucariotos, embora consigam identificar cerca de 95\% dos nucleotídeos das regiões codificantes, identificam somente cerca de 50\% dos genes corretamente (Stanke e Waack, 2003). Esse desempenho menor para identificar os genes se dá principalmente por conta da dificuldade que os preditores têm em encontrar corretamente os sítios de splincing (fronteiras entre éxons e íntrons) e o início da região de tradução, uma vez que qualquer erro na determinação desses sítios provoca uma predição incorreta.

As duas abordagens mais utilizadas na construção de preditores de genes são, a intrínseca ou $a b$ initio e a extrínseca. Mais recentemente, abordagens híbridas que combinam num mesmo preditor as duas anteriores vêm ganhando espaço na área por conta de seus bons resultados, como por exemplo o conseguido por Stanke et al. (2006).

\subsection{Predição extrínseca}

A predição extrínseca é feita a partir de alinhamentos que podem vir de genomas de referência ou de projetos de análise de transcritos. A princípio qualquer algoritmo de alinhamento pode ser usado para realizar a predição extrínseca para se obter uma provável distribuição de éxons dos genes no genoma. Isso é possível uma vez que as regiões codificantes são mais conservadas em relação às não-codificantes (Verli, 2014).

É frequente se referir aos preditores extrínsecos como programas de alinhamento divido (spliced alignment' programs) (Mathé et al., 2002). Os preditores extrínsecos tentam encontrar um alinhamento que utilize os transcritos mantendo a sua ordem de disposição em diferentes regiões do genoma. Além disso, os sítios de splicing são alinhados com regiões compatíveis com as sequências consenso de início e final de íntron. Algoritmos de programação dinâmica como BLAT (Kent, 2002), Exonerate (Slater e Birney, 2005) e PASA (Haas et al., 2003) são frequentemente empregados nos alinhamentos.

Exonerate e BLAT usam a estratégia de alinhamentos a partir de sementes, que são pequenos trechos de sequência. Essas sementes são alinhadas (com bancos de dados ou conjuntos de sequências) e sucessivamente estendidas para formar pares de trechos com pontuações (scores) mais altas. Vários desses pares são unidos para formar o alinhamento final. PASA foca na montagem de grupos de alinhamentos de transcritos (ESTs e cDNAs) sobrepostos para identificar variantes de splicing alternativos. Assim como BLAT e Exonerate, PASA usa algoritmos de programação dinâmica para realizar os alinhamentos e as suas junções.

A comparação de sequências genômicas de espécies próximas é uma alternativa para relevar 
regiões codificantes. ROSETTA (Batzoglou et al., 2000) é um preditor que ataca o problema de predição partindo da hipótese de que a estrutura éxon-íntron de sequências de espécies próximas é conservada e de que os éxons tem aproximadamente o mesmo comprimento. GLASS, GLobal Alignment SyStem (Batzoglou et al., 2000), é um programa que recebe duas sequências de organismos próximos como entrada e realiza o alinhamento global das mesmas a procura de loci sintênicos via programação dinâmica. A partir desse alinhamento global, ROSETTA identifica as regiões de éxons codificantes em ambas as espécies baseada nas coincidências da estrutura do gene encontrada.

\subsection{Predição de genes ab initio}

Os preditores ab initio utilizam apenas a sequência alvo (de entrada) para realizar a predição. Eles avaliam como as bases estão distribuídas na sequência alvo para determinar (inferir) potenciais regiões que compõe genes. Para reconhecer essas diferentes regiões, os preditores se utilizam basicamente de dois tipos de sensores probabilísticos: sensores de sinais e sensores conteúdo.

Sinais biológicos são trechos conservados característicos dos elementos da estrutura usados como marcadores dessas regiões. Diversos sinais biológicos atuam durante os processos de transcrição, de splicing do pré-RNAm e de tradução. Na predição de genes os sinais modelados mais importantes (Figura 2.3) são:

- o sítio de início de transcrição que indica a região da sequência onde se inicia a transcrição e que pode conter uma região conservada $\mathrm{A}+\mathrm{T}$ rica, chamada TATA-box

- o sítio doador de íntron (donnor site) que indica o início do íntron e contém geralmente a sequência conservada $\mathrm{AG}$

- o sítio aceitador de íntron (acceptor site) que indica o fim do íntron e contém geralmente a sequência GT

- o códon de início tradução ATG e os códons de terminação TAA, TAG, e TGA

Os sensores de sinais tentam reconhecer esses sinais que são trechos de tamanho conservados e os sensores de conteúdo tentam reconhecer os trechos de tamanho variável como éxon, íntron e região intergênica.

Um modelo integrador descreve a arquitetura de um gene utilizando os sensores de sinal e e os sensores de conteúdo. O algoritmo principal de decodificação realiza a predição compondo a probabilidade do modelo integrador com as probabilidades dos modelos dos sensores. Como dito no Capítulo 3, a grande maioria dos preditores de genes atacam o problema de predição com Cadeias de Markov Generalizadas (GHMMs) como modelo agregador e Viterbi como algoritmo principal de decodificação.

\subsubsection{Preditores $a b$ initio}

\section{EasyGene}

EasyGene (Larsen e Krogh, 2003), um preditor de genes procarioto explora essas características por meio de HMM simplificando um gene em uma ORF(Open Reading Frames). ORFs são trechos de sequência na mesma fase de leitura que contém um códon de início e um códon de fim e não 
possuem códon de fim internos. Como a estrutura do gene de procariotos é mais simples, ORFs são potenciais regiões codificantes. ORFs de diversos organismos foram traduzidas para suas proteínas correspondentes e essas proteínas foram alinhadas com as proteínas presentes no Swiss-Prot (UniProtKB/Swiss-Prot, um banco de sequências de proteínas anotadas não redundantes de alta qualidade $)^{1}$. O conjunto de treinamento foi construído com as ORFs que tiveram alinhamentos significativos com alguma proteína do banco. Os parâmetros (probabilidades de transição e emissão) do HMM (Figura 4.2) são estimados com o algoritmo Baum-Welch que encontra os valores dos parâmetros do modelo que maximiza a probabilidade do conjunto de treinamento e o algoritmo posterior decoding é usado na decodificação da sequência durante a predição.

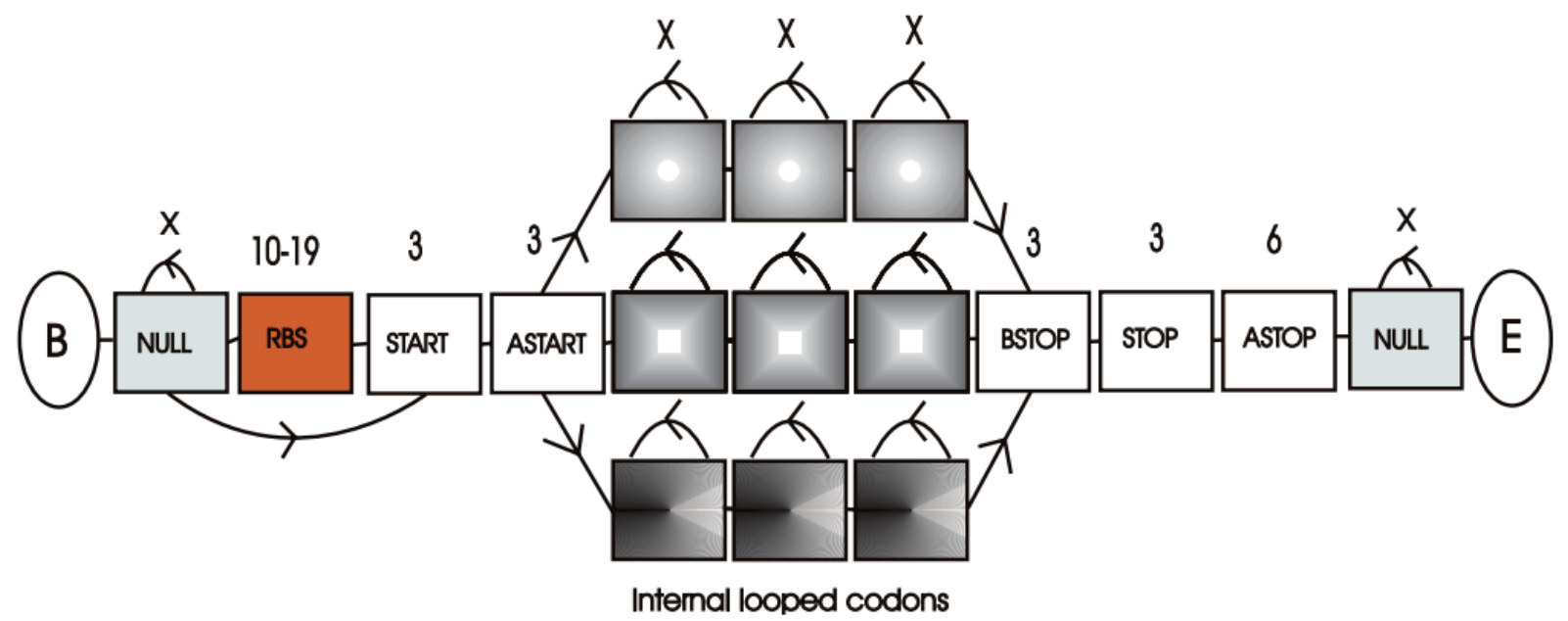

Figura 4.2: Cada caixa corresponde a um submodelo com mais de um estado. O número acima de cada caixa representa o número de bases modeladas pelo submodelo da caixa e ' $X$ ' indica um número variável. Como o modelo busca identificar ORFs na sequência, estados da vizinhança do códon início e fim são modelados (RBS, ASTART e BSTOP e ASTOP respectivamente) são modelados para reforçar o sinal de códon de início e fim. Os três loops para compor a região codificadora foram escolhidos especificamente para se obter um ajuste empírico de distribuição de tamanhos mais realista do que a distribuição de tamanhos da HMM (com um loop) que é intrinsecamente geométrica. (Larsen e Krogh, 2003).

\section{Genscan}

Um importante marco na área de predição de genes foi o preditor Genscan(Burge e Karlin, 1997). Boa parte das suas propostas de modelagem probabilística da estrutura de genes codificadores de proteínas foram bem sucedidas e influenciaram a construção de outros preditores eucariotos que o sucederam. Tais avanços incluíram a possibilidade de predição de múltiplos genes, de genes parciais, da predição nos dois sentidos da sequência e da escolha do modelo GHMM usado na predição em função da proporção de bases CG (Axelson-Fisk, 2015).

Os genomas dos vertebrados são mosaicos de isochores, trechos muito longos (>300 kb) de DNA que são homogêneos na composição de base e pertencem a um pequeno número de grupos que diferem a proporção do conteúdo GC (Bernardi, 2000). Diferentes conjuntos de parâmetros do GHMM são derivados para explicar esses diferentes mosaicos de densidade de conteúdo CG e estrutura dos genes observados no genoma humano (Burge e Karlin, 1997).

Genscan agrupa os conjuntos de treinamento em quatro categorias em função do conteúdo GC (menor que $53 \%$, entre $43 \%$ - 51\% e $51 \%$ - 57\% e maior que $57 \%$ ) para treinar os parâmetros de

\footnotetext{
${ }^{1}$ https://web.expasy.org/docs/swiss-prot_guideline.html
} 
quatro GHMMs. A primeira etapa do processo de predição é analisar o conteúdo GC da sequênciaalvo para então aplicar dentre os quatro modelos treinados, o modelo correspondente a conteúdo CG da sequência.

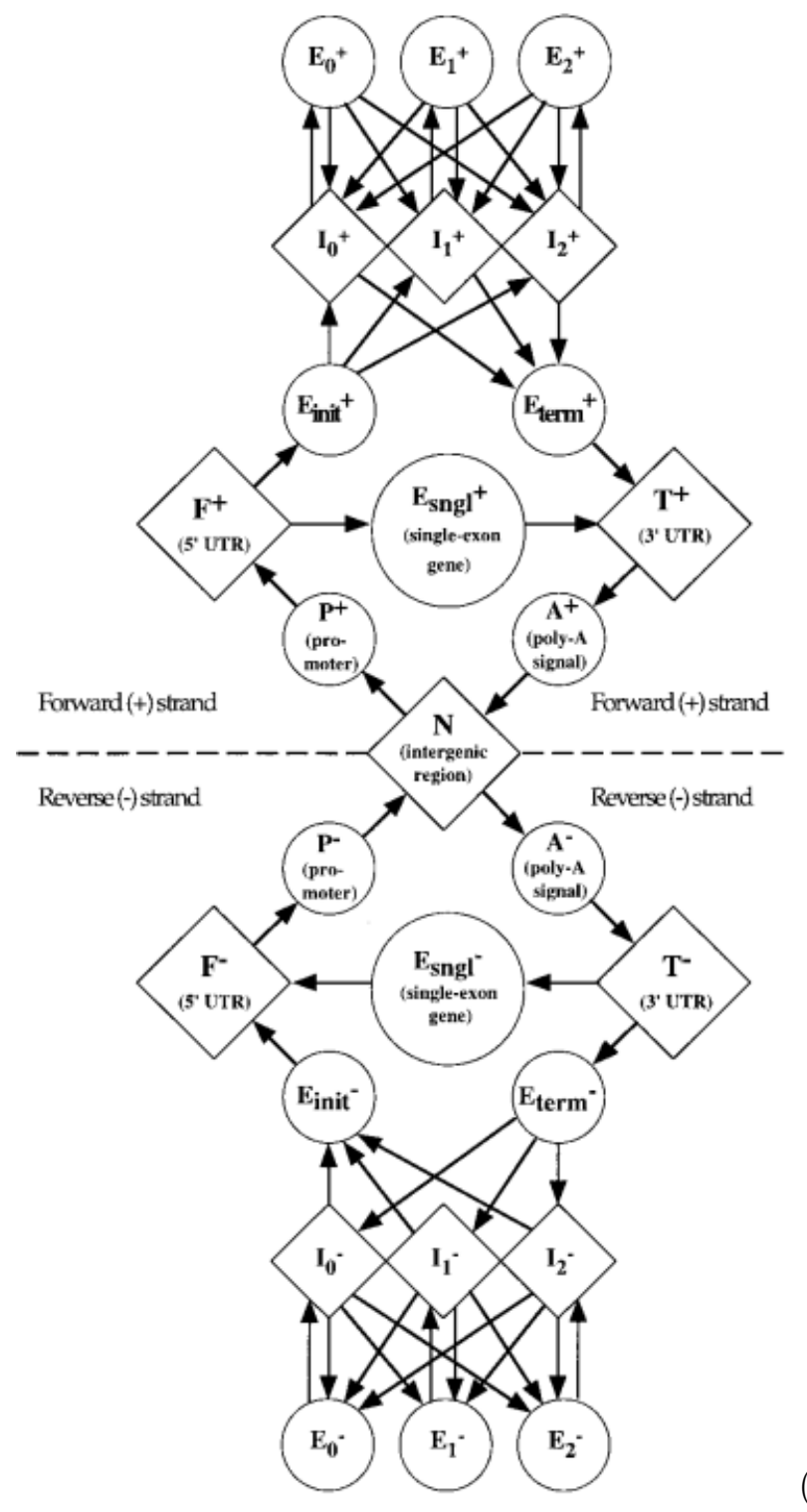

(Burge e Karlin, 1997).

Figura 4.3: Os estados da GHMM do Genscan. Para modelar a análise dos dois sentidos da sequência (5'3' e 3'5'), Genscan constrói uma GHMM conectando no estado N (região intergênica) duas GHMM, uma para o modelo da estrutura do gene eucarioto no sentido 5'3' e a outra, o espelho dessa, para o modelo da estrutura do gene no sentido inverso 3'5'. O ciclo iniciado no estado $N$ permite a predição de mais de um gene numa única sequência e a ausência de estados de início e fim permite a predição de genes parciais. Todas essas características embutidas na GHMM de Genscan foram posteriores incorporados nos preditores Augustus (Stanke e Waack, 2003) e MYOP, esse último inicialmente desenvolvido por Kashiwabara (2012)

\section{Augustus}

Augustus (Stanke e Waack, 2003) foi outro preditor bem sucedido e de grande importância na área de predição de genes. O modelo agregador de submodelos de Augustus (Figura 4.4) é uma GHMM similar ao de Genscan com uma modelagem não geométrica para a região de íntron.

As dependências de posições das bases encontradas nas regiões intergênicas e regiões de íntrons são muito menores do que as encontradas nas regiões codificantes. Por conta disso os preditores até 
então modelavam os tamanhos dos íntrons com distribuições geométricas. Entretanto, a distribuição geométrica é uma aproximação ruim para íntrons curtos, por exemplo $63 \%$ dos íntrons de Drosophila são menores que 100 nucleotídeos (Stanke e Waack, 2003).

O Augustus ataca esse problema com uma nova proposta para modelagem de distribuição dos tamanhos dos íntrons. Um íntron é modelado por três estados para caracterizar íntrons longos e íntrons curtos, ao invés da modelagem com um único estado com auto transição (distribuição geométrica) que caracteriza íntrons de qualquer tamanho. A Figura 4.5 mostra os três estados de íntron adicionais cujos modelos de emissão são Cadeias de Markov de alcance igual a 4 treinados com todas as sequências não codificantes do conjunto do treinamento. 


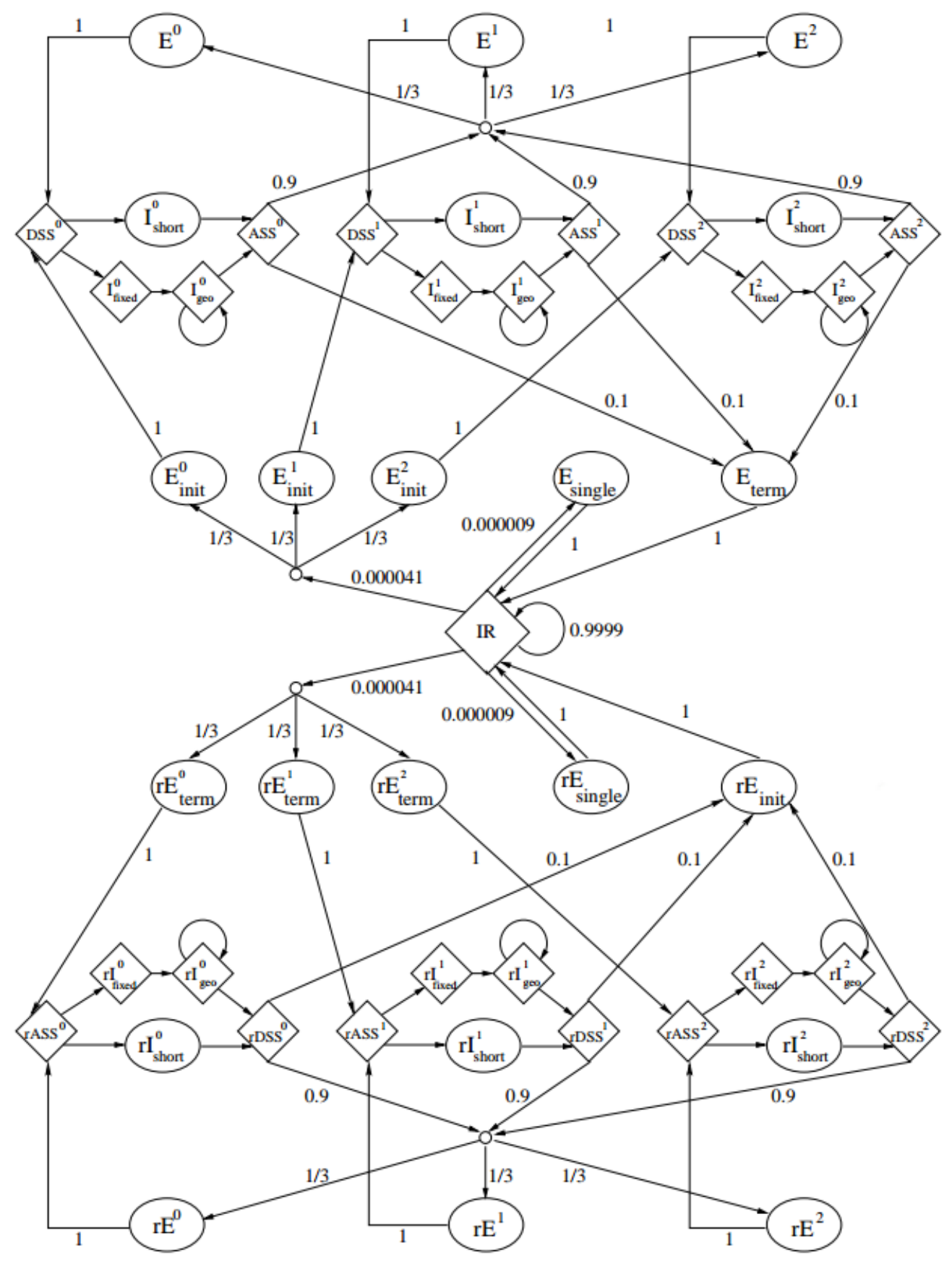

forward strand

reverse strand

Figura 4.4: Os estados do Augustus e as possiveis transições entre eles. Estados representados por losangos emitem cadeias de tamanho fixo e estados representados por círculos ovais emitem cadeias de tamanho explícito. Os expoentes descrevem a fase de leitura e o números acima das arestas as probabilidades de transição (Stanke e Waack, 2003). 


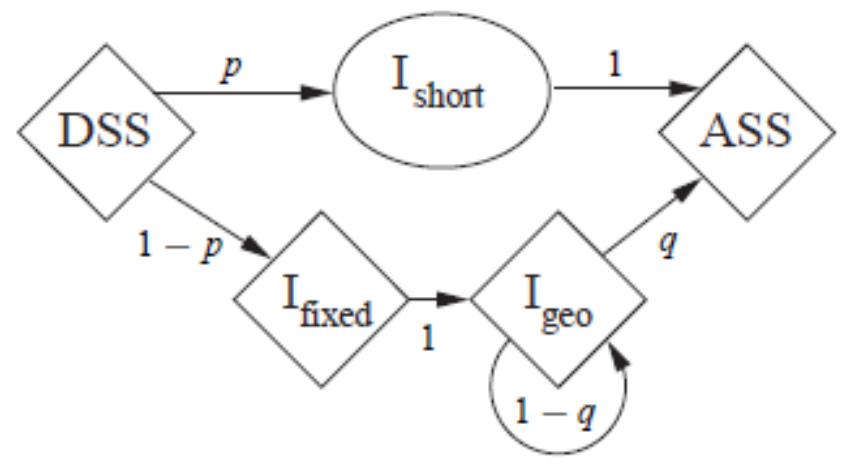

Figura 4.5: Submodelo de distribuição de tamanhos de introns. I geo emite um nucleotídeo por vez, $I_{f i x e d}$ emite sequências de tamanho $d$ e $I_{\text {short }}$ emite sequências de tamanho $l \leq d$. Íntrons curtos, ou seja com tamanhos $l \leq d$, com d uma constante máxima que depende do organismo (exemplo $d=929$ para Drosophila e $d=584$ para humano) são modelados pelo estado $I_{\text {short }}$ com duração explícita, ou seja, a probabilidade de duração segue uma distribuição que normalmente não é uma distribuição fixa (ou constante) nem é geométrica. Íntrons com tamanhos $l>d$ são modelados com dois estados, o estado $I_{\text {fixed }}$ com distribuição de tamanho (fixo) constante d e outro estado $I_{\text {geo }}$ com duração geométrica por conta da autotransição. (Stanke e Waack, 2003).

Assim como Genscan, Augustus prevê a estrutura do gene eucarioto da sequência por meio do algoritmo de decodificação Viterbi GHMM. Genes aninhados ou sobrepostos e pseudogenes ${ }^{2}$ confundem os algoritmos de decodificação e são umas das grandes dificuldades dos preditores $a b$ initio. No caso dos genes alinhados, os algoritmos de decodificação dos modelos markovianos decidem pela rotulação do gene de maior probabilidade, desconsiderando a possibilidade de dois ou mais genes num mesmo trecho de sequência, pois cada posição da sequência recebe apenas uma rotulação (algum estado do modelo). Além disso as próprias arquiteturas GHMM (Figuras 4.3 e 4.4) forçam que, se mais de um gene for predito na sequência, eles devem estar separados por uma região intergênica.

Ao se construir modelos, espera-se que eles sejam genéricos o suficiente para que novas sequências (que não fizeram parte do treinamento) sejam bem classificadas, ou seja, o preditor determine com eficiência a localização dos genes. Os dois problemas mais comuns que ocorrem em sistemas que possuem modelos que são treinados, como os preditores ab initio, são Overfitting e Overpredicting. Overfitting é um problema que ocorre quando os modelos representam muito bem as sequências de treinamento tendo um excelente desempenho de classificação para elas, porém ao avaliar sequências que não fazem parte do conjunto de treinamento seu desempenho cai consideravelmente. Isso ocorre quando os conjuntos de treinamento não representarem bem o universo de objetos que se deseja avaliar. Este problema tem como consequência geralmente a diminuição da sensibilidade da predição ${ }^{3}$. Overpredicting ocorre quando a quantidade de classificados (preditos no caso) é maior do que o esperado provocando um número grande de falsos positivos, tornando a precisão ${ }^{4}$ baixa. Isso ocorre quando o modelo é genérico demais, ou seja, ele não conseguiu modelar as características avaliadas; provavelmente por conta de uma variedade muito excessiva e não representativa dos objetos do conjunto que se deseja avaliar ou até mesmo pelo próprio processo de treinamento.

\footnotetext{
${ }^{2}$ Pseudogenes são sequências não codificantes que muito se assemelham aos genes

${ }^{3}$ Sensibilidade é a razão entre os verdadeiros positivos (TP) e a soma dos verdadeiros positivos com os falsos negativos (FN), ou seja, Sensibilidade $=\frac{T P}{T P+F N}$

${ }^{4}$ Precisão (PPV) é a razão entre os verdadeiros positivos (TP) e a soma dos verdadeiros positivos e falsos positivos (FP), ou seja, $\mathrm{PPV}=\frac{T P}{T P+F P}$,
} 


\subsection{Predição híbrida de genes}

Os métodos de predição híbrida de genes combinam as abordagens ab initio (ou intrínsecas) e extrínseca num mesmo preditor. Esse tipo de abordagem é o foco desse trabalho e será explorado com mais detalhes no Capítulo 5 a partir do estudo das metodologias de mapeamento usadas nos preditores Augustus (Stanke et al., 2006) e Twinscan (Korf et al., 2001) que seguem essa abordagem.

\subsection{Predição com múltiplas fontes}

Não podemos deixar de mencionar que a maioria dos trabalhos mais recentes relacionados à predição de genes não são direcionados ao desenvolvimento de novos preditores e sim na tentativa de juntar predições de preditores anteriormente publicados. Acreditamos que isso ocorre por conta da dificuldade de desenvolvimento de novos modelos que sejam mais eficientes do que empregados nos preditores anteriores.

Um exemplo dessa abordagem é o preditor FunGAP. Ele (Min et al., 2017) emprega três preditores Augustus, Maker (Cantarel et al., 2008) e GeneMark (Lukashin e Borodovsky, 1998) no seu processo de predição. Ele executa cada preditor separadamente com a sequência alvo e contigs de transcritos e escolhe a melhor predição dentre as três predições. O critério de escolha é feito submetendo cada um dos três preditos a três ferramentas: BLASTp (Boratyn et al., 2013), BUSCO (Simão et al., 2015) e Pfam (Finn et al., 2016). O gene predito que obtiver a melhor soma de scores dessas três ferramentas é o selecionado pelo FunGAP. Esse critério reforça a confiabilidade da predição pois considera similaridades existentes entre proteínas conhecidas e validadas. Ao alinhar o gene predito com BLASTp contra um banco de proteínas, FunGAP analisa a homologia do predito em relação as proteínas conhecidas; ao confrontar com o BUSCO analisa se há sequências ortólogas, ou seja, proteínas de outras espécies similares ao predito; e por fim, considera se há domínios funcionais no predito comparando-o com o banco de dados Pfam. Em seus resultados, FunGAP conseguiu diminuir o número de falsos positivos indicando que essa abordagem de predição com múltiplas fontes é promissora e que pode ser ainda mais aprimorada. 


\section{Capítulo 5}

\section{Métodos de predição híbrida}

Evidências extrínsecas de uma sequência alvo são indícios a respeito da estrutura de um ou mais genes nessa sequência. Em geral, são obtidas a partir de alinhamentos de uma sequência com proteínas ou trechos de sequências expressas. Também podem ser obtidas a partir das similaridades encontradas em sequências homologas. Porém, as sequências utilizadas como fonte de evidências extrínsecas podem conter erros vindos dos processos de sequenciamento, além de normalmente fornecem informações incompletas a respeito da estrutura completa do gene. Contudo, essas evidências se combinadas as evidências intrínsecas da sequência alvo, ou seja, se combinadas aos modelos $a b$ initio podem ajudar nas predições reforçando os sinais biológicos do gene.

Os métodos de predição híbrida de genes combinam as abordagens intrínsecas (ou ab initio) e extrínsecas num mesmo preditor. Nossa pesquisa revelou apenas dois métodos de predição híbrida. O primeiro, presente no preditor Twinscan (Korf et al., 2001), incorpora no modelo ab initio sequências homólogas à sequência alvo. O segundo, presente no preditor Augustus+ (Stanke et al., 2006), incorpora alinhamento da sequência alvo com proteínas ou com sequências expressas.

\subsection{Método de predição utilizado no Twinscan}

Twinscan é um aperfeiçoamento do Genscan (descrito na seção 4.2.1) para a inclusão de informação de mapeamento de alinhamento de genomas eucariotos anotados. A ideia original para melhorar a anotação automática de genomas é inserir no modelo probabilístico informações de genes anotados de organismos próximos do organismo da sequência alvo. As informações de mapeamento de uma sequência alvo são construídas com base em alinhamentos da sequência alvo contra o genoma informante. Esse alinhamento é sintetizado em uma sequência, chamada sequência de conservação, que representa o grau e o padrão de divergência evolucionária entre os dois genomas em cada ponto ao longo da sequência (Hu e Brent, 2003).

A sequência de conservação é uma sequência do mesmo tamanho da sequência alvo formada por três símbolos: 'l', '.' e ':'. Cada um desses símbolos emparelha com um nucleotídeo da sequência alvo da seguinte forma:

- . não alinhado $(g a p)$

- | alinhado com coincidência de conteúdo (matched)

- : alinhado com divergência de conteúdo (mismatched) 
No artigo do Twinscan (Korf et al., 2001) há o exemplo a seguir de construção da sequência de conservação a partir do alinhamento de uma sequência alvo de tamanho 9 contra sequências do genoma informante:
123456789 posições
GAATTCCGT sequência alvo

Suponha o seguinte alinhamento local de uma sequência alvo com uma sequência informante:

$3456789 \quad$ posições da sequência alvo

ATT-CCGT alinhamento da sequência alvo

| | | | | símbolos que alinharam com o BLAST

ATCACC-T alinhamento da sequência informante

Para a formação da sequência de conservação considere que gaps na sequência alvo são ignorados (gap entre a posição 5 e 6) e que gaps na sequência informante são considerados mismatch (mismatch na posição 8). Assim, a sequência conservada construída com base na sequência alvo e no alinhamento local anteriories é:
123456789 posições
GAATTCCGT sequência alvo
. ||$:||: \mid$ sequência de conservação

Sequências de conservação de treinamento são obtidas de alinhamentos de sequências de treinamento já anotadas contra sequências do um genoma informante. Com as anotações das sequências de treinamento, trechos das sequências de conservação são separados e agrupados em conjuntos de trechos de sequências de conservação de CDS (região codificante do gene), de íntron e de região intergênica. Esses conjuntos de trechos são usados para treinar cadeias de Markov de ordem 5, e são essas cadeias de Markov que serão incorporadas no cálculo da probabilidade conjunta da sequência alvo e da sequência de conservação no modelo GHMM.

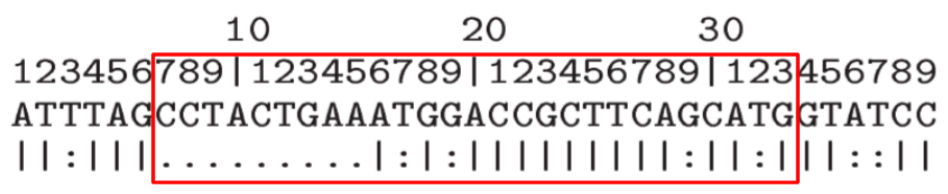

Figura 5.1: Uma sequência de DNA junto com sua correspondente sequência conservada. Figura alterada de Korf et al. (2001).

Nesse mesmo artigo há o exemplo a seguir que ajuda a entender como essa probabilidade conjunta é calculada. Considere a sequência alvo e a sequência conservada da Figura 5.1. Seja $T_{7,33}$ um trecho de uma sequência alvo que inclui a posição 7 até a posição 33 , seja $C_{7,33}$ um trecho de uma sequência conservada e $E_{7,33}$ a hipótese de que há um éxon nesse mesmo intervalo. Assim,

$$
P\left(T_{7,33}, C_{7,33} \mid E_{7,33}\right)=P\left(T_{7,33} \mid E_{7,33}\right) \times P\left(C_{7,33} \mid E_{7,33}\right),
$$

onde $P\left(T_{7,33} \mid E_{7,33}\right)$ é a probabilidade do trecho da sequência alvo dado um éxon nesse intervalo sob o modelo de Genscan e $P\left(C_{7,33} \mid E_{7,33}\right)$ é a probabilidade do trecho da sequência conservada sob o modelo de conservação. O modelo de conservação de $P\left(C_{7,33} \mid E_{7,33}\right)$ é a cadeia de Markov de ordem 5 treinada com o conjunto de trechos de sequências de conservação de éxon. A probabilidade $P\left(C_{7,33} \mid E_{7,33}\right)$ é a extensão que o Twinscan traz ao modelo de Genscan por meio das informações 
de alinhamentos locais. Como essa probabilidade é uma cadeia de Markov de ordem 5, então:

$$
P\left(C_{7,33} \mid E_{7,33}\right)=P_{\text {exon }}\left(C_{7,7} \mid C_{2,6}\right) \times P_{\text {exon }}\left(C_{8,8} \mid C_{3,7}\right) \times \ldots P_{\text {exon }}\left(C_{33,33} \mid C_{28,32}\right),
$$

onde $P_{\text {exon }}\left(C_{33,33} \mid C_{28,32}\right)$, por exemplo, é estimada da probabilidade de existir um símbolo | (de match) após um contexto de 5 símbolos $(|:| \mid:)$ na sequência de conservação sob o modelo de conservação de éxon.

Com esse exemplo de cálculo de probabilidade de um trecho específico da sequência de conservação sob um modelo de conservação de éxon, generalizamos a partir da Equação 5.2 o cálculo para um trecho da sequência de conservação de tamanho d sob o modelo de conservação $k$ :

$$
P\left(C_{i-d+1, i} \mid k\right)=\prod_{j=i-d+1}^{\mathrm{i}} P_{k}\left(C_{j, j} \mid C_{j-5, j-1}\right) .
$$

Com a incorporação da sequência de conservação no cálculo da probabilidade da sequência alvo, a probabilidade conjunta da sequência alvo e da sequência de conservação, torna a recursão do algoritmo Viterbi GHMM (Equação 3.10):

$$
v_{l}(i+1)=\max _{k, d} v_{k}(i-d) a_{k l} f_{l}(d) e_{l}\left(x_{i-d+1}^{i}\right) P\left(C_{i-d+1, i} \mid k\right) .
$$

Embora o treinamento das cadeias de Markov de ordem 5 com os trechos das sequências de conservação seja necessário para o cálculo da Equação 5.4, existem arquivos de configuração já prontos para diversas espécies, bastando informar esse arquivo, a sequência alvo e sequência de conservação para realizar a predição.

\subsection{Método utilizado no Augustus+}

Augustus+(Stanke et al., 2006) é uma extensão do preditor Augustus(Stanke e Waack, 2003) para que o mesmo incorpore informações de mapeamento de alinhamentos de transcritos e/ou de proteínas de eucariotos anotados. Esses alinhamentos são realizados contra a sequência genômica de interesse e são utilizados para gerar dicas (hints). Dicas são sugestões de um tipo de evidência de informação extrínseca (evidência de estruturas de genes) na sequência alvo.

Cada dica está associada a um elemento da estrutura do gene e esse elemento define o tipo da dica. A versão original do artigo (Stanke et al., 2006) define 6 tipos diferentes: start, stop, dss, ass, exonpart, exon. Assim como os elementos da estrutura do gene podem ter tamanhos fixos como o códon de início ou tamanhos variáveis como íntrons e éxons, as dicas também podem ter tamanhos fixos ou variáveis.

- tipos de dicas de tamanho fixo: start (sítio de início de tradução), stop (códon de terminação), $d s s$ (sítio 3' doador de íntron), ass (sítio 5' aceitador de íntron)

- tipos de dicas de tamanho variável: exon (evidência da posição exata de início e de fim de um éxon) e exonpart (evidência de que um trecho é parte de um éxon).

A categoria da dica, ou seja, qual a origem do alinhamento que foi usado para produzi-lo, é mais uma informação relevante associada as informações extrínsecas modeladas no preditor. Basicamente 
há quatro categorias diferentes para as origens: Transcrito, Proteína, Combinado e Manual. A categoria transcrito, significa que a dica foi produzida a partir de alinhamentos de transcritos de EST (transcritos que funcionam como marcadores de região codificante) ou de RNA-Seq. A categoria Proteína significa que a dica foi produzida a partir de alinhamentos de proteínas, a categoria Combinada significa que a dica de transcrito foi confirmada por um alinhamento com uma proteína e a categoria Manual indica que uma dica foi definida pelo próprio usuário.

Além disso, uma dica pode estar associada ou a uma posição da sequência alvo $s$ ou a um trecho da mesma. A seguir são representados os 6 tipos de dicas. Duplas são usadas para representar dicas associadas a uma posição de $s$ e quadruplas para dicas associadas a um trecho da sequência alvo.

Dicas associadas a uma posição específica de $s$ :

1. $h_{i, \text { start }}=($ category, strand $)$

dica (hint) da posição específica $i$ que representa um possível códon de início (start) na sequência s. Category é uma das quatro categorias que representam a origem da dica e strand é direção de $s$ (forward ou reverse).

2. $h_{i, \text { stop }}=($ category, strand $)$

dica da posição específica $i$ que representa um possível códon de final de tradução (stop) na sequência $s$.

3. $h_{i, d s s}=($ category, strand $)$

dica da posição específica $i$ que representa um possível sítio doador de íntron ( $d s s)$ na sequência $s$.

4. $h_{i, \text { ass }}=($ category, strand $)$

dica da posição específica $i$ que representa um possível sítio aceitador (ass) de íntron na sequência $s$.

Dicas associadas a um trecho específico de $s$ :

$5 h_{i, \text { exon_part }}=$ (category, strand, length, reading_frame $)$

dica que indica que um trecho de $s$ que se inicia na posição $i$ e termina na posição $i+$ length é parte de um éxon (exonpart). Em geral essas dicas estão localizadas nas extremidades do alinhamento onde não se tem certeza se o éxon é parcial ou se o éxon tem um trecho de UTR (região não transcrita). Reading_frame é uma das três possíveis fases de leitura (0, 1 ou 2).

$6 h_{i, \text { exon }}=($ category, strand, length, reading_frame $)$

dica que indica a posição exata de início $(i)$ e fim de um éxon $(i+$ length $)$.

Para uma mesma posição $i$ da sequência alvo $s$ pode haver mais de um tipo de dica, estas dicas podem ou não serem conflitantes. Caso não haja um dica em uma posição $i$, o que ocorre na maioria dos casos, como por exemplo a dica de start, $h_{i, \text { start }}=\psi$, a letra $\psi$ para representar a ausência de dicas.

Os parâmetros de probabilidade das dicas são treinados considerando a distribuição de frequência de acertos de rotulação $\phi$ associada a um trecho de $s$ e frequência de acertos de compatibilidade de bases em relação a rotulação $\phi$ de um conjunto de treinamento. Acertos de rotulação ocorrem 
quando as dicas combinam com determinado trecho da estrutura do gene, por exemplo dicas de éxon combinam com rotulações de estados de éxon. Acertos de compatibilidade de bases ocorrem quando as dicas combinam com as bases do trecho, por exemplo as bases ATG são compatíveis com dicas de start, éxon e íntron, e não são compatíveis com dicas de stop (as bases ATG não podem pertencer a um stop códon, mas podem pertencer a um start, um éxon ou um íntron).

Para entender melhor como esses parâmetros são calculados, há no artigo original um exemplo de cálculo da frequência de acertos de rotulação e de compatibilidade das bases de trechos da sequência $s, q^{+}$(start,protein); e de frequência de acertos somente de compatibilidade das bases, $q^{-}$(start, protein) de dicas do tipo start produzidos por alinhamentos de proteínas. Essas frequências são usadas para determinar o valor estimado da probabilidade das dicas do tipo start, na posição $i$ dado a rotulação $\phi$ e a sequência $s: P\left(h_{i, \text { start }} \mid \phi, s\right)$.

Nesse exemplo, o conjunto de treinamento para a estimação de $P\left(h_{i, \text { start }} \mid \phi, s\right)$ foram sequências com estruturas de genes conhecidas. Nessas sequências conhecidas, 386 dos 500 códons de início ATGs receberam a evidência de dicas de códon início de tradução. A contagem dessas dicas usada no cálculo de $q^{+}$(start, protein) consiste no número das dicas que acertam a rotulação e que estão associados a posição da sequência cujas bases são ATG, ou seja, compatíveis com a rotulação de start. Em contrapartida, 47 dos 145.000 ATGs que não eram códons de início (eram metionina) também receberam a evidência de dicas de códon início de tradução. A contagem dessas dicas de start que erram a rotulação das bases ATG, mas que as bases são compatíveis (ATG) com a dicas de start é usado no cálculo de $q^{-}$(start, protein).

De modo geral para uma dica do tipo $t$ e categoria $g$ :

- $q^{+}(t, g)$ é a frequência de acertos de estrutura (rotulação) $\phi$ e de compatibilidade com os nucleotídeos do trecho da sequência $s$.

- $q^{-}(t, g)$ é a frequência de acertos de compatibilidade com os nucleotídeos do trecho da sequência $s$, porém que erraram a estrutura $\phi$.

Com isso, para o exemplo anterior, temos:

$$
\begin{gathered}
q^{+}(\text {start }, \text { protein })=386 / 500 \approx 0.77 \\
q^{-}(\text {start }, \text { protein })=47 / 145000 \approx 3.2 \times 10^{4}
\end{gathered}
$$

São esses valores estimados que são incorporados no modelo probabilístico GHMM do preditor Augustus, originando o Augustus +. Essa incorporação é realizada no algoritmo de Viterbi GHMM durante a computação da probabilidade conjunto de trechos da sequência e da sua rotulação. Como há esse novo elemento, a dica, o cálculo da probabilidade conjunta deve levá-la também em consideração. O cálculo da probabilidade conjunta da rotulação $\phi$, da sequência $s$ e das dicas $h$ assume duas suposições simplificadoras:

1. dicas de diferentes posições $i$ de $s$ são independentes.

2. dicas de diferentes tipos de uma mesma posição $i$ de $s$ são independentes.

Dessa forma, a probabilidade conjunta da rotulação $\phi$, da sequência $s$ e da dica $h \mathrm{P}(\phi, s, h)$ é: 


$$
\begin{aligned}
P(\phi, s, h) & =P(\phi, s) \times P(h \mid \phi, s) \\
& =P(\phi, s) \times \prod_{i=1}^{|\mathrm{s}|} P\left(h_{i, t} \mid \phi, s\right), t \in T Y P E
\end{aligned}
$$

onde TYPE é o conjunto de tipos de dicas e:

- $\mathrm{P}(\phi, s)$ é probabilidade conjunta da rotulação $\phi$ e da sequência $s$ sob o modelo GHMM (Figura 4.4) do Augustus original (Stanke e Waack, 2003).

- $\mathrm{P}\left(h_{i, t} \mid \phi, s\right)$ é a probabilidade da dica do tipo $t$ na posição $i$ da sequência $s$ dada a rotulação $\phi$ e a sequência $s$. É a conversão dos dados de alinhamento em valores de probabilidades que são incorporados ao GHMM e que dão origem ao modelo GHMM híbrido Augustus $+($ Stanke et al., 2006)

No cálculo de $\mathrm{P}\left(h_{i, t} \mid \phi, s\right)$ outra suposição simplificadora é adotada: $\mathrm{P}\left(h_{i, t} \mid \phi, \mathrm{s}\right)$ depende somente do tipo $t$ da dica, da categoria $g$, se for compatível com a estrutura $\phi$ e se for compatível com $s$. Dessa forma, se $h_{i, t} \neq \psi$ (a letra $\psi$ indica ausência de dica), ou seja há a dica $h_{i, t}$ do tipo $t$ na posição $i$ da sequência, a $\mathrm{P}\left(h_{i, t} \mid \phi, s\right)$ assume os valores treinados de $q^{+}(t, g)$ e $q^{-}(t, g)$ da seguinte forma:

$$
P\left(h_{i, t} \mid \phi, s\right)= \begin{cases}q^{+}(t, g) & \text { se } h_{i, t} \text { é compatível com } \phi \\ q^{-}(t, g) & \text { se } h_{i, t} \text { é compatível com com } s \text { mas não é com } \phi \\ 0, & \text { caso contrário }\end{cases}
$$

Com a incorporação de $h_{i, t} \neq \psi$ no cálculo da probabilidade conjunta $P(\phi, s, h)$, a recursão do algoritmo Viterbi GHMM (Equação 3.10) torna-se:

$$
v_{l}(i+1)=\max _{k, d} v_{k}(i-d) a_{k l} f_{l}(d) e_{l}\left(x_{i-d+1}^{i}\right) \prod_{i-d+1}^{\mathrm{i}} P\left(h_{i, t} \mid k, x_{i-d+1}^{i}\right), t \in T Y P E, h_{i, t} \neq \psi,
$$

Além desses 6 tipos de dicas descritos anteriormente, a versão 3.3 do Augustus $+{ }^{1}$ conta com mais 11 tipos - tss, tts, intronpart, intron, CDSpart, CDS, UTRpart, UTR, irpart, nonexonpart, genicpart - para os quais não há fórmula descrita no artigo, pois foram otimizações implementadas após a publicação.

Embora $q^{+}(t, g)$ e $q^{-}(t, g)$ façam parte da teoria para estimar os valores de probabilidade de uma dica $P\left(h_{i, t} \mid \phi, s\right)$, na versão mais recente do Augustus + (versão 3.3 até a data desse trabalho) não há rotinas ou scripts para realizar o treinamento proposto de $q^{+}(t, g)$ e $q^{-}(t, g)$. Dessa forma, o uso do Augustus + atualmente é diferente do proposto no artigo original, como veremos a seguir.

\footnotetext{
${ }^{1}$ http://bioinf.uni-greifswald.de/augustus/
} 


\section{Capítulo 6}

\section{Um preditor com contribuições extrínsecas de fontes de alinhamento}

Como pode ser observado no Capítulo 5, as técnicas de mapeamento empregadas nos preditores Augustus e Twincan envolvem algoritmos muito diferentes, porém o produto do mapeamento de cada técnica pode ser visto de uma maneira única e reunido em uma matriz. Nesse Capítulo proporemos a unificação dos algoritmos pela construção teórica de uma matriz probabilística de contribuição extrínseca e apresentaremos a nossa modificação do algoritmo de Viterbi GHMM para o uso dessa matriz. Abordaremos também a nossa modelagem e implementação sob o arcabouço ToPS.

\subsection{Uma proposta de modificação do Algoritmo de Viterbi}

Apesar dos algoritmos de Twinscan e Augustus parecerem bastante diferentes, podemos construir uma modelagem unificada. A seguir estão as recursões do algoritmos de Viterbi de Twinscan e Augustus discutidas no Capítulo 5:

Algoritmo de Viterbi Twinscan:

$$
v_{l}(i+1)=\max _{k, d} v_{k}(i-d) a_{k l} f_{l}(d) e_{l}\left(x_{i-d+1}^{i}\right) P\left(C_{i-d+1, i} \mid k\right),
$$

Algoritmo de Viterbi Augustus:

$$
v_{l}(i+1)=\max _{k, d} v_{k}(i-d) a_{k l} f_{l}(d) e_{l}\left(x_{i-d+1}^{i}\right) \prod_{i-d+1}^{\mathrm{i}} P\left(h_{i, t} \mid k, x_{i-d+1}^{i}\right), t \in T Y P E, h_{i, t} \neq \psi,
$$

onde TYPE é o conjunto de tipos de dicas.

A proposta desse trabalho consiste em unificar a maneira a qual Twinscan e Augustus modelam os valores de probabilidade das informações extrínsecas. Essa unificação é alcançada por meio de uma matriz de contribuição extrínseca que generaliza as contribuições que os dados de alinhamento fornecem as variáveis de Viterbi. Dessa maneira, a variável de Viterbi $v_{l}(i+1)$ pode ser representada com a seguinte recursão: 


$$
v_{l}(i+1)=\max _{k, d} v_{k}(i-d) a_{k l} f_{l}(d) e_{l}\left(x_{i-d+1}^{i}\right) \prod_{i-d}^{i} M[k][i]
$$

onde, para Twinscan:

$$
M[k][i]=P\left(C_{i-d+1, i} \mid k\right)=\prod_{j=i-d+1}^{\mathrm{i}} P_{k}\left(C_{j, j} \mid C_{j-5, j-1}\right)
$$

e para Augustus

$$
M[k][i]=\prod_{i-d+1}^{\mathrm{i}} P\left(h_{i, t} \mid k, x_{i-d+1}^{i}\right), t \in T Y P E, h_{i, t} \neq \psi
$$

Nessa nova modelagem, as diferenças entre os algoritmos são mapeadas na inicialização da matriz de contribuição extrínseca M [k ] [i] e com essa unificação também podemos facilmente acrescentar novos esquemas de contribuição.

A Figura 6.1 mostra o pseudocódigo das principais etapas e variáveis envolvidas no algoritmo Viterbi GHMM implementado no método viterbi da classe GeneralizedHiddenMarkovModel do ToPS. Esse método é central durante todo o processo de predição, pois o caminho (oculto) ótimo de estados da sequência alvo retornado por esse método é usado como entrada para o script do MYOP tops_to_gtf ${ }^{1}$ para gerar o arquivo gtf final da predição híbrida.

\footnotetext{
${ }^{1}$ https://github.com/ayoshiaki/myopTemplates/tree/master/scripts
} 


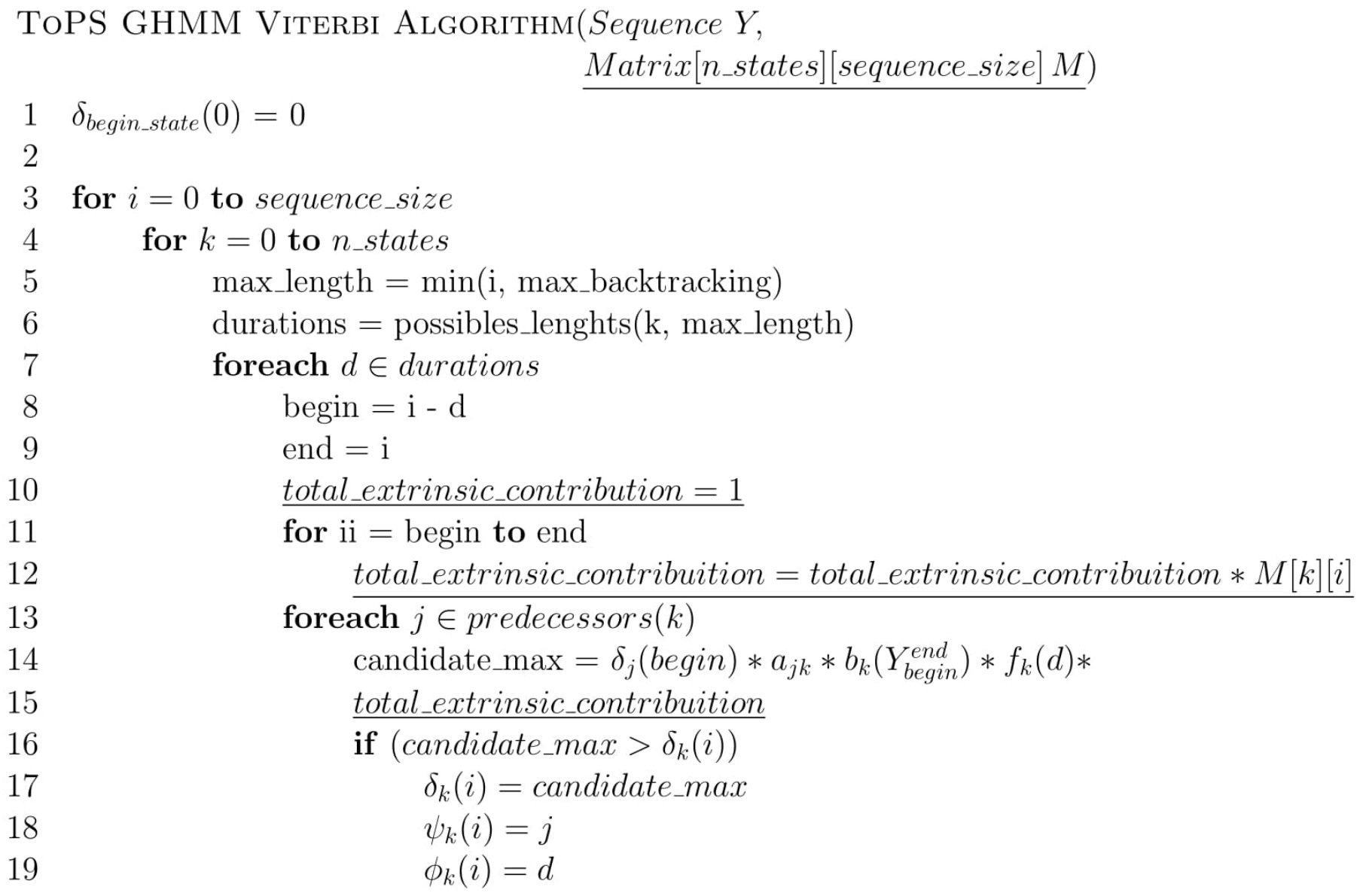

20

$21 \max =\delta_{\text {end_state }}($ sequence_size $)$

22 label $=\operatorname{traceBack}(\mathrm{Y}, \psi, \phi)$

23 return label

Figura 6.1: A matriz $M$ sintetiza toda a informação de alinhamento. Para cada trecho de tamanho d da sequência $Y$ (tamanho de uma possível duração do estado k), os pesos das contribuições extrínsecas armazenados nos campos da matriz referente a linha (associado a esse estado $\mathrm{k}$ ) e as colunas (associados ao trecho, $\left.i i_{1} \in(i-d, i)\right)$ são acumulados na variável total_extrinsic_contribuition (linha 6-12). Esse valor acumulado é usado para ajustar a probabilidade de rotulação desse trecho com os estados $k$ associado a esse tipo de dica (linhas 14-15). Os trechos grifados destacam as partes do algoritmo responsáveis por acumular os valores da contribuição extrínseca, e juntar esse valor acumulado à variável Viterbi corrente $\left(\delta_{j}(\right.$ begin $\left.)\right)$, à probabilidade de transição do estado j para o $\mathrm{k}\left(a_{j k}\right)$, à probabilidade de emissão $\left(b_{k}\left(Y_{\text {begin }}^{\text {end }}\right)\right.$ e à probabilidade de duração $\left(f_{k}(d)\right)$ do estado $\mathrm{k}$. Uma vez determinado o maior valor de probabilidade na posição i no estado $k$ ele é armazenado na matriz de Viterbi $\left(\delta_{j}(i)=\right.$ max_candidate), assim como são armazenado em matrizes o estado $j$ predecessor de $k\left(\psi_{k}(i)=j\right)$ e a duração do estado $k\left(\phi_{k}(i)=d\right)$ (linhas 16-19). Essas três matrizes são utilizadas no final do algoritmo por um procedimento de rastreio (traceBack $(Y, \phi, \psi))$ que encontra o conjunto de estados ocultos mais prováveis (label) da GHMM para a sequência alvo $Y$ levando em conta as contribuições fornecidas pela matriz $M$ (linha 22). 


\subsection{Implementação da modelagem unificada de contribuições ex- trínsecas}

\subsubsection{ToPS}

ToPS (Toolkit of Probabilistic Models of Sequence) é um arcabouço orientado a objetos de propósito geral para implementação, manipulação e combinação de modelos probabilísticos para representar e segmentar sequências de símbolos. Como um arcabouço de desenvolvimento, o ToPS fornece um conjunto de classes que auxiliam a implementação e composição de modelos probabilísticos. Ele é bastante útil para qualquer área que deseja descrever fenômenos que exibem padrões de regularidade como a Bioinformática e a Estatística.

Além desse conjunto de classes para desenvolvimento, o ToPS conta com um conjunto de aplicativos de linha de comando disponíveis para tarefas de simulação, classificação e decodificação de sequências, e de treinamento de modelos. Para realizar essas tarefas, basta o usuário especificar as características dos modelos em arquivos texto e executar os aplicativos com esses arquivos como parâmetro. Especificar em arquivos texto as características dos modelos disponíveis no ToPS é bastante intuitivo, uma vez que arcabouço conta com uma linguagem de especificação bastante simples que facilita o seu uso por usuário não programadores. A Figura 6.2 mostra o arquivo de configuração da HMM da Figura 3.2 que modela a caracterização de humor de pacientes com depressão e sem depressão (normal).

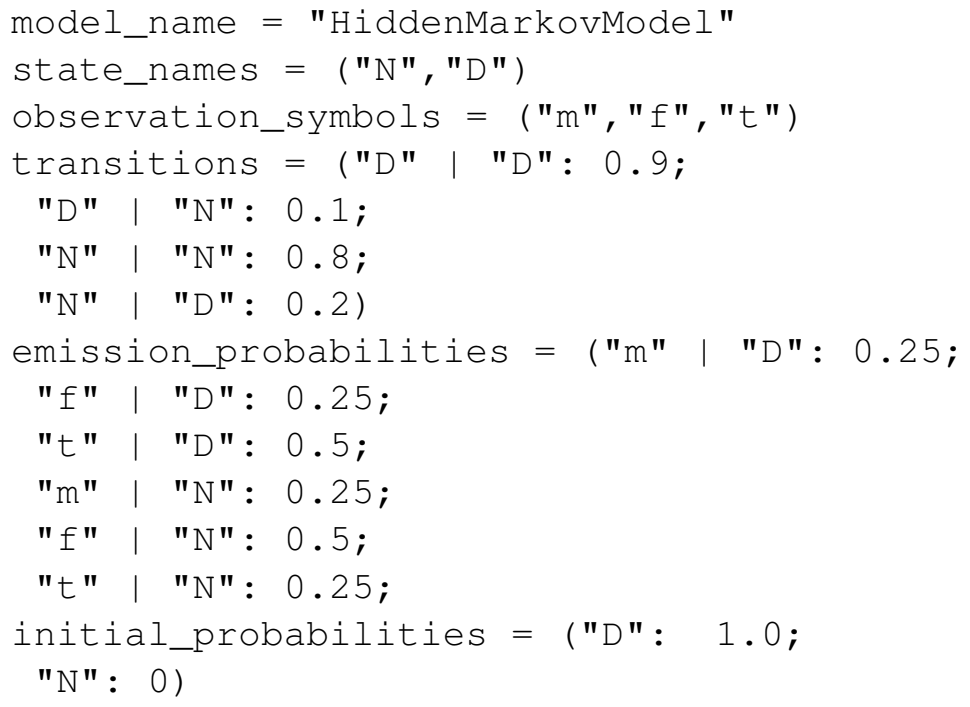

Figura 6.2: Arquivo texto que especifica um modelo HMM hipotético que caracteriza o humor de pacientes com depressão e sem depressão (normal). Nesse arquivo todos os parâmetros do modelo probabilístico são definidos.

A publicação do ToPS (Kashiwabara et al., 2013) disponibilizou diversos modelos probabilísticos, entre os quais destacam-se para esse trabalho as Cadeias de Markov, Cadeias Ocultas de Markov (HMM) e a Cadeias Ocultas de Markov Generalizadas (GHMM). Após a publicação, o arcabouço continuou sendo base para novos projetos de pesquisa que adicionaram novos modelos. Ígor Bonadio no seu mestrado (Bonadio, 2013) incluiu os modelos de LCCRF (Linear-Chain Conditional Random Field, Campos Aleatórios Condicional de Cadeias Lineares) e no seu no seu doutorado (Bonadio, 2018) inclui os modelos de semi-CRF (Semi-Markov Conditional Random Fields, Campos Aleató- 
rios Condicionais Semi-Markovianos). Rafael Ferreira no seu mestrado (Ferreira, 2015) adicionou ao arcabouço o modelo csHMM (context sensitive Hidden Markov Model, Cadeia de Markov de estados ocultos sensível ao contexto).

Essas extensões, embora tenham aumentado o leque de opções de modelos probabilísticos disponíveis, também fizeram crescer bastante o código fonte do arcabouço tornando mais complexo o seu entendimento e como não haviam testes no arcabouço, as novas implementações poderiam inserir bugs nos modelos já implementados. Além disso, como os modelos LCCRF e semi-CRF possuem funções de características (funções que não são necessariamente probabilísticas e que podem ser implementadas numa linguagem de programação) ao invés de funções de distribuição de probabilidade, foi necessário estender o suporte da linguagem de especificação do ToPS para acomodar os modelos LCCRF e semi-CRF que definem esse tipo de função.

Nesse contexto, Ígor Bonadio e Renato Cordeiro (Cordeiro, 2015) iniciaram a refatoração do ToPS com principal objetivo de facilitar a adição de novos modelos probabilístico. Até a data desse trabalho, a refatoração não foi concluída, porém já proporcionou grandes melhorias ao arcabouço e destacam-se:

- a refatoração dos modelos de Markov HMM e GHMM.

- a substituição do repositório online de código SourceForge pelo repositório online de código GitHub. Essa substituição deu suporte as melhorias abaixo.

- o desenvolvimento de uma bateria de testes de unidade para os modelos refatorados

- a criação de uma infraestrutura de integração contínua com Travis que possibilita que a cada commit enviado ao repositório ( $p u s h$ ) do arcabouço, o Travis executa toda a bateria de testes e informa aos desenvolvedores do repositório o resultado desses testes.

\subsubsection{Arquitetura do ToPS}

A arquitetura atual do ToPS utiliza o padrão Composite (Gamma et al., 1995), onde a classe ProbabilisticModel, raiz da hierarquia, define a interface das classes componentes; e a classe DecodableModel define a interface das classes compositoras. Essas classes compositoras utilizam os componentes indiretamente por meio de estados, que são agregados de modelos probabilísticos que representam a emissão, transição e duração desses estados.

Outro ponto a se destacar nessa hierarquia de classes é o uso do jargão CRTP (Curiously Recurring Template Pattern) que é uma técnica utilizada para simular herança dinâmica, mas, nesse caso as chamadas dos métodos são resolvidas em tempo de compilação; em contrapartida as chamadas de herança dinâmica que são resolvidas em tempo de execução. Esta técnica é utilizada para implementar Mixin ${ }^{2}$, ausente em $\mathrm{C}++$; mas presente em outras linguagens orientadas a objetos como Ruby.

A classe ProbabilisticModelCRTP injeta os métodos de fábrica que criam os diferentes Secretários ${ }^{3}$ que compõem um modelo probabilístico qualquer do arcabouço. Além disso, essa classe

\footnotetext{
${ }^{2}$ https://ruby-doc.com/docs/ProgrammingRuby/html/tut_modules.html

${ }^{3}$ No padrão Secretário (Ferreira et al., 2016), Secretários são classes que encapsulam as chamadas dos métodos das classes Chefes e Chefes são classes que detêm a implementação dos métodos. No arcabouço, Secretários são as classes que encapsulam os métodos de treinamento, avaliação, rotulação e geração de sequências dos Chefes, as classes dos modelos probabilísticos.
} 
declara os métodos que representam os comportamentos desses Secretários. Para utilizar o CRTP, uma subclasse herda de uma especialização da classe ProbabilisticModelCRTP, passando seu próprio tipo como argumento do template.

A Figura 6.3 destaca na arquitetura do ToPS o padrão Composite e o uso do CRTP para instanciação (especialização) do template Derived como uma classe de GHMM e a Figura 6.4 mostra a hierarquia de classe completa do ToPS gerada pela ferramenta de documentação Doxigen ${ }^{4}$.

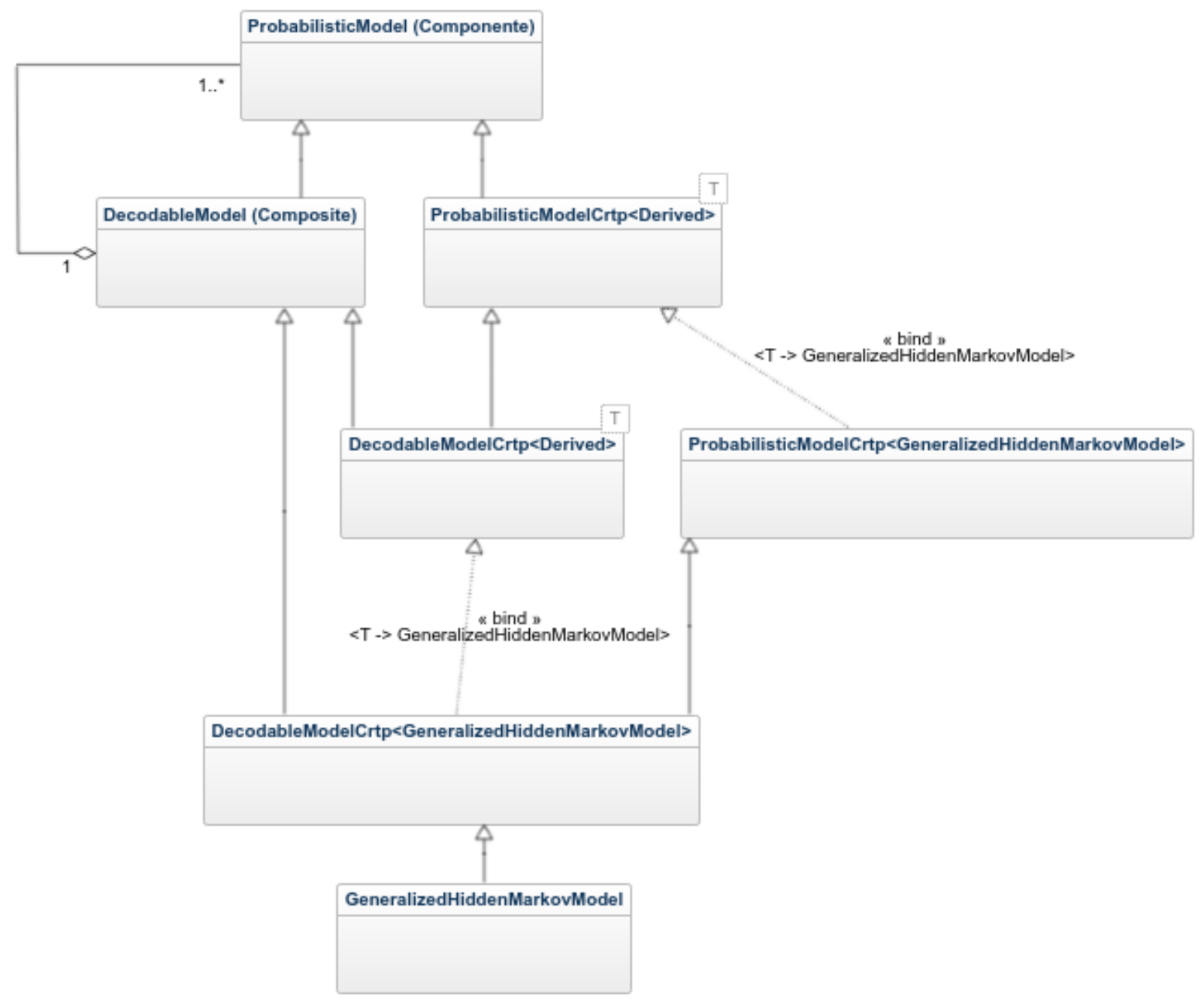

Figura 6.3: Uma classe abstrata é uma classe a qual todos os seus métodos são puramente virtuais (Stroustrup, 2013). A classe ProbabilisticModel é uma classe abstrata que declara os métodos de fábrica de Secretários (avaliadores, geradores, treinadores e serializadores de sequência) comuns a todos os modelos probabilísticos. A classe DecodableModel, outra interface, declara os métodos de fábrica de Secretários (calculadores e rotuladores de sequências) exclusivos dos modelos HMM e GHMM que realizam decodificação de sequências. Esses métodos de fábrica são implementados de modo genérico (como templates Derived) pelas classes ProbabilisticModel Crtp e DecodableModelCrtp e são sobrescritos (implementados de modo especializado) nas diferentes classes filhas, as classes de modelos probabilísticos que são as classes folhas da hierarquia do ToPS. As setas pontilhadas indicam o binding, a amarração da implementação genérica do template $T$ (Derived) com a implementação específica da classe GeneralizedHiddenMarkovModel.

\footnotetext{
${ }^{4}$ Site do Doxygen: http://www.doxygen.nl
} 


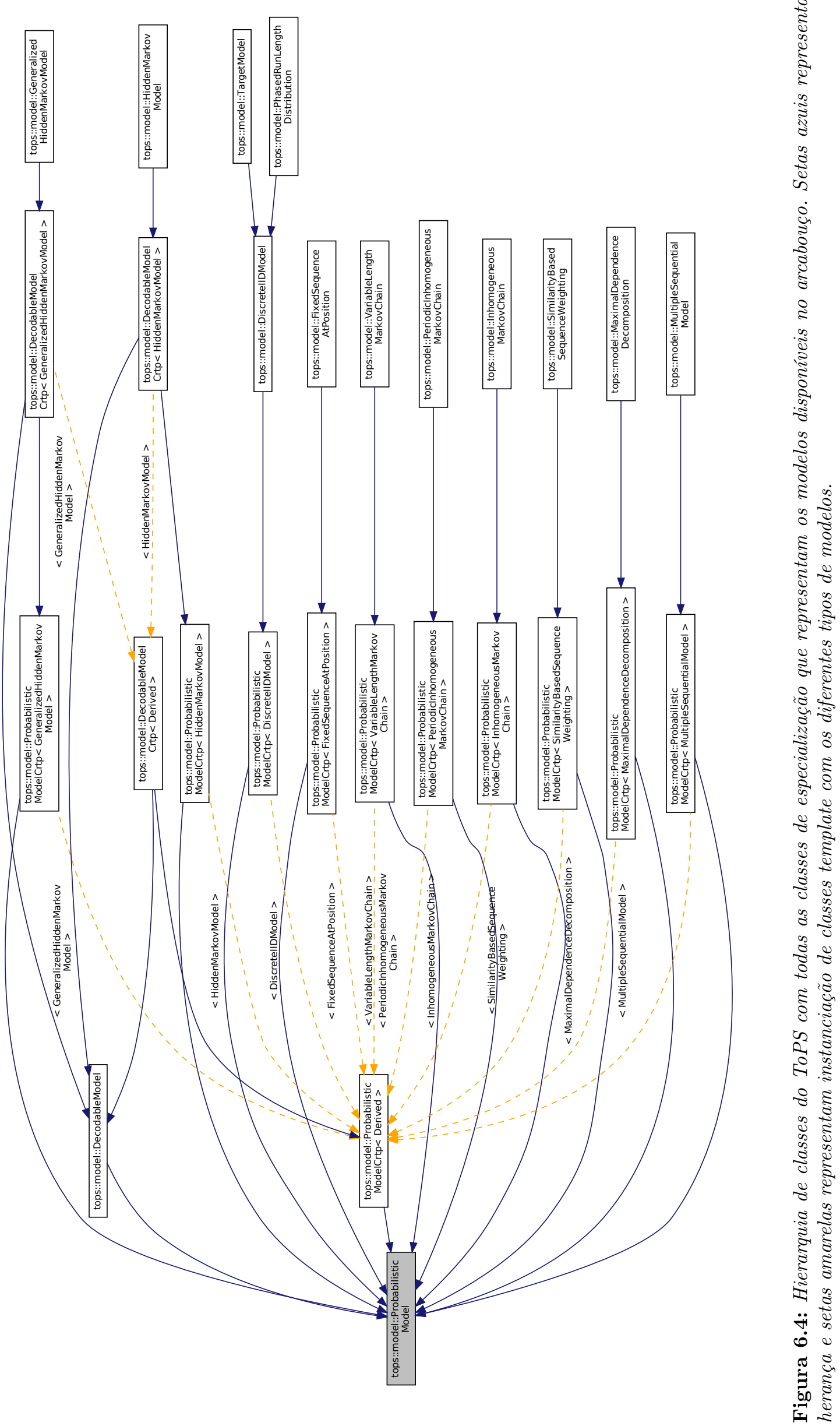




\subsection{Predição unificada com MYOP em $\mathrm{C}++$}

A maioria dos preditores de genes disponíveis atualmente, inclusive os vistos no Capítulo 4, possuem seu modelo probabilístico inserido no próprio código fonte do programa. Essa maneira de construção de preditores que amarra intimamente os modelos probabilístico e o código fonte dificulta a comparação e entendimento de resultados de diferentes estratégias, pois não é possível saber se um preditor ab initio obteve melhores resultados do que outros por conta da sua arquitetura principal, de seus submodelos ou dos próprios algoritmos de otimização, como Viterbi, Forward e Backward implementados. Esses problemas acarretados pelo alto acoplamento (da modelagem probabilística dentro do código fonte) presente nos preditores foi identificado por Kashiwabara (2012) e o motivou a desenvolver o arcabouço ToPS e o sistema de predição MYOP.

MYOP (Make Your Own Predictor) é um sistema para implementação de preditores ab initio e um preditor de genes em si que apresenta resultados competitivos nos comparativos realizados por nosso grupo de pesquisa face a concorrência dos melhores preditores disponíveis. Seu grande diferencial é modelar o problema de predição em cima de um arcabouço genérico de implementação de modelos probabilísticos, ToPS, separando os detalhes internos de implementação dos modelos da arquitetura do preditor. Dessa forma, o MYOP fica responsável pela modelagem probabilística e entendimento do problema de predição de genes enquanto o ToPS fica responsável por disponibilizar toda a infraestrutura necessária, ou seja, implementar todos os algoritmos dos modelos que compõe os estados da arquitetura $a b$ initio da estrutura do gene. Esse ambiente onde essa separação é clara, no qual se tem um arcabouço que disponibiliza bibliotecas para implementação de modelos probabilísticos e um sistema que auxilia a criação de arquiteturas de preditores, torna oportuno o desenvolvimento do método de predição que unifique diferentes técnicas de incorporação de informações extrínsecas proposto por esse trabalho.

Como visto no Capítulo 6, o ToPS (Kashiwabara et al., 2013) está em processo de refatoração. Até a data desse trabalho, as refatorações do módulo responsável pela especificação da linguagem e do módulo que reúne as ferramentas de linha de comando para treinamento, simulação e decodificação de sequências não foram concluídas, mas estão em processo de finalização.

O MYOP usa o módulo de linguagem do ToPS para especificar em arquivos texto os modelos e a arquitetura do preditor. Este módulo converte os arquivos textos em objetos do ToPS e vice-versa e é o responsável pela integração entre MYOP e ToPS publicado (Kashiwabara et al., 2013). Contudo, como a refatoração do módulo de linguagem do ToPS refatorado não foi concluída até a data desse trabalho, MYOP e o ToPS refatorado não estão integrados, impossibilitando o uso conjunto dos mesmos no desenvolvimento desse trabalho. Além disso, no processo de predição, MYOP executa os aplicativos de linha de comando do ToPS como tops-viterbi_decoding, e como a refatoração dos aplicativos também não foi concluída, ainda não é possível integrar MYOP e ToPS refatorado. Só após o término da refatoração essa integração ocorrerá.

O fato de não haver essa integração, impossibilitou o uso dos arquivos de configuração que especificam os modelos probabilísticos e seus os algoritmos de treinamento. Isso resultou num desafio adicional desse trabalho: construir uma versão simplificada em $\mathrm{C}++$ do MYOP original usando diretamente as bibliotecas em $\mathrm{C}++$ do ToPS refatorado. Essa versão simplificada foi construída e chamada de MYOP $\mathrm{C}++{ }^{5}$.

\footnotetext{
${ }^{5}$ https://github.com/topsframework/tops/tree/feature/myop-cpp
} 
O MYOP $\mathrm{C}++$ foi implementado com a mesma GHMM de 67 estados do MYOP original, formada por 33 estados para representar a sequência senso, 33 para a sequência reversa e um estado (N) para região intergênica. Também foram adicionados dois estados silenciosos (que não emitem símbolos e possuem duração fixa, constante, igual 0): o estado B (begin), o primeiro estado da GHMM, e o estado E (end), o último estado. A vantagem de se incluir esses estados na GHMM é simplificar as etapas de inicialização e termino dos algoritmos de Viterbi da GHMM. A inserção desses estados na GHMM, bem como generalizações nos algoritmos de modelos markovianos, fazem parte do trabalho de mestrado em andamento de Renato Cordeiro que consiste em criar uma implementação integrada de modelos probabilísticos gráficos.

A primeira etapa da construção do MYOP $\mathrm{C}++$ foi implementar o treinamento dos modelos de duração e emissão que compõe os 67 estados. Como os submodelos de transição de todos os estados são IIDs, não foi necessário implementar os seus treinamentos, bastando a instanciação da classe DiscreteIIDModel com a distribuição de probabilidade de transição de cada estado.

O script myop-train.pl ${ }^{6}$ do MYOP realiza o treinamento de um conjunto de sequências. Ele segmenta as sequências de treinamento em arquivos com trechos e tamanhos desses trechos referentes a diferentes regiões do gene. Esses arquivos são usados para treinar os diferentes submodelos de emissão e de duração dos estados que compõe a GHMM do MYOP C ++ . Por exemplo, o script myop-train.pl extrai das sequências de treinamento os trechos de sequências de éxon e armazena esses trechos no arquivo cds. fasta e os seus tamanhos no arquivo single. length. O arquivo cds. fasta é usado no treinamento da probabilidade de emissão dos estados de éxon único e éxon único reverso (ES e rES respectivamente na Figura 6.5) do MYOP C ++ simplificado. Da mesma forma, os tamanhos das sequências de éxon armazenados no arquivo single. length são usados no treinamento da probabilidade de duração dos estados de éxons internos e éxon único.

A Figura 6.5 mostra a GHMM do MYOP C ++ composta pelos 69 estados. Destaca-se (em azul) os estados silenciosos, estados os quais não estão presentes na GHMM do MYOP.

\footnotetext{
${ }^{6}$ https://github.com/ayoshiaki/myop/blob/master/scripts/myop-train.pl
} 


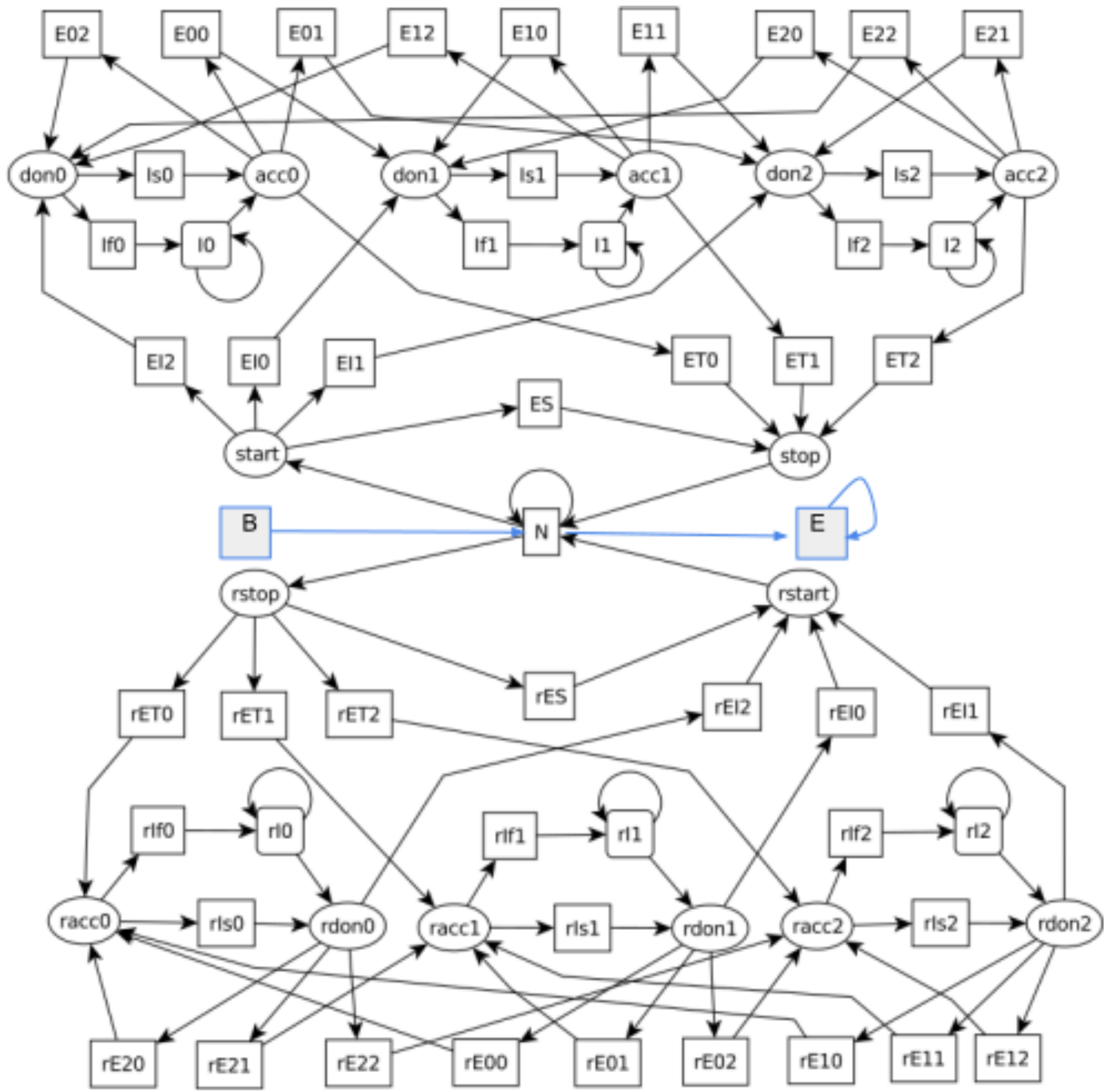

Figura 6.5: A arquitetura da GHMM do MYOP $C++$ simplificado é a mesma arquitetura do preditor $M Y O P$ original desenvolvida por Kashiwabara (2012) com a adição dos estados $B$ (begin) e $E$ (end) em azul. O estado B, primeiro estado da GHMM, não emite símbolo (estado silencioso), transita para o estado $N$ (estado de região intergenica) com probabilidade 1 e duração 0 . O estado E, estado final, também não emite símbolo, transita para si mesmo (auto-transição) e duração 0.

\subsubsection{Extensão do ToPS}

A proposta inicial era modelar a implementação dos algoritmos de predição híbrida de Twinscan e Augustus + no ToPS criando duas subclasses da classe Generali zedHiddenMarkovModel para representar a GHMM capaz de incorporar as informações extrínsecas de Augustus e Twinscam. Cada uma dessas classes encapsularia toda a maneira de extração de informações de alinhamento (EST e RNASeq) e processamento dessas informações convertendo-as em valores numéricos. Além disso, cada subclasse teria sua própria implementação do algoritmo de Viterbi que levaria em conta esses valores numéricos.

Contudo, um entendimento maior do problema mostrou que não seria necessário implementar essas duas subclasses, sendo substituídas pela inserção da matriz M [k] [i] . Essa solução facilita a adição de novos métodos de predição com evidências extrínsecas além dos métodos de Twinscan e Augustus, e além disso, torna possível a combinação de métodos por meio da combinação de suas respectivas matrizes.

Como visto no Capítulo 5, Twinscan e Augustus são métodos bastante diferentes. O primeiro usa 
alinhamento da sequência de interesse contra sequências genômicas de algum organismo próximo para construir a sequência de conservação. Essa sequência de conservação é então usada para calcular a probabilidade conjunta da sequência alvo e da sequência de conservação dada uma rotulação. O segundo método, Augustus, usa alinhamentos de transcritos como fonte de informação extrínseca para apontar a localização de dicas nas regiões na sequência de interesse.

O mapeamento das informações de alinhamento define prováveis localizações de regiões do gene e esse mapeamento é convertido em valores numéricos para ajustar as probabilidades dos submodelos dos estados da GHMM associados às regiões alinhadas. O mapeamento foi implementado com o padrão de projeto Strategy(Gamma et al., 1995) (Figura 6.6) para que as diferentes técnicas de mapeamento pudessem ser unificadas de forma genérica por meio da classe ExtrinsicTechnique (StrateGy). Com esse padrão, além das técnicas abordadas nesse trabalho (Augustus e Twinscan), novas técnicas podem ser adicionais ao MYOP $\mathrm{C}++$ sem muito esforço. Basta estender a classe ExtrinsicTechnique e implementar o algoritmo de interface makeContribuition que lida com os mapeamento e retorna uma matriz de contribuição extrínseca.

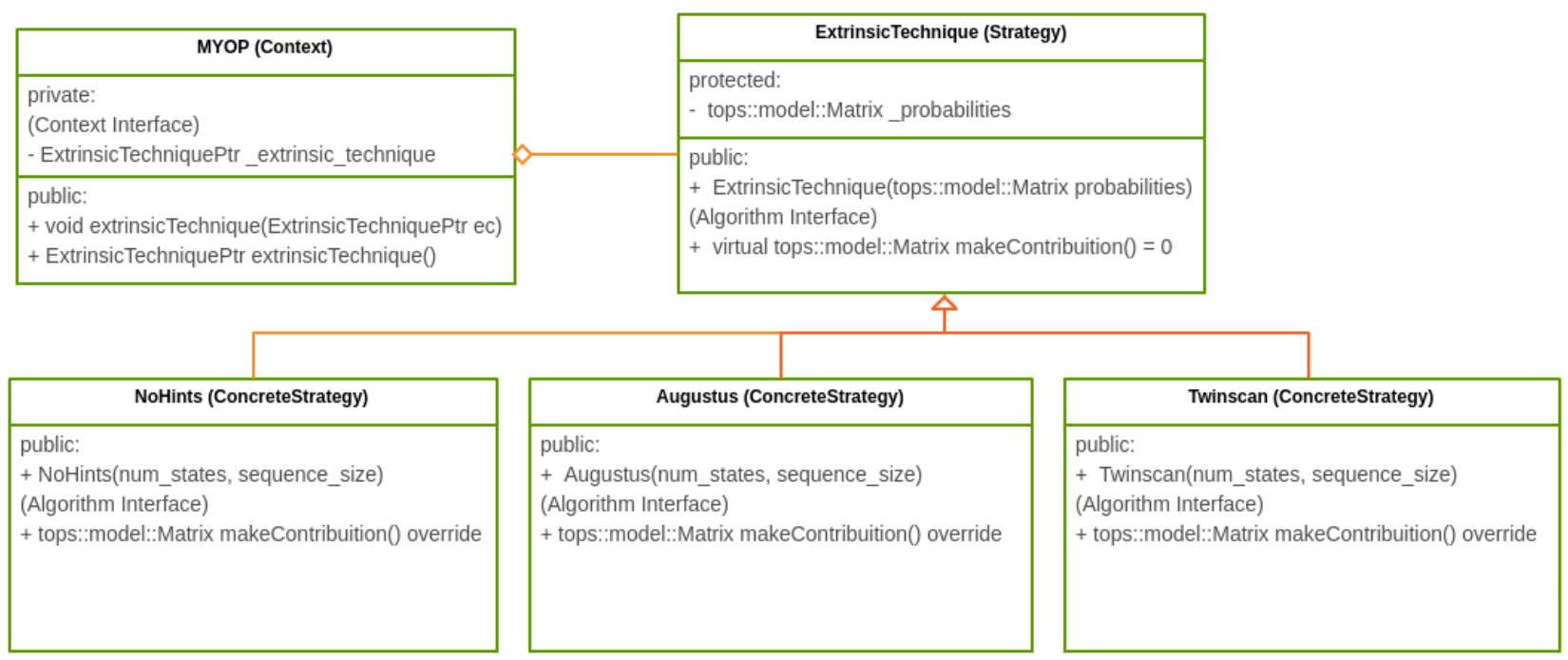

Figura 6.6: As diferentes técnicas de mapeamento são subclasses de ExtrinsicTechnique e devem tratar as informações de alinhamento a sua maneira e retornar uma matriz numérica cujas linhas representam o estados e as colunas representam as posições da sequência a ser analisada. Um campo dessa matriz numérica apresenta a contribuição de um estado em uma posição da sequência. Por exemplo, a posição Matrix[1][99] da matriz de contribuição representa a contribuição que as informações de alinhamento trazem para a posição 100 no estado de 1 (start). A matriz segue o padrão do $C++$, linhas e colunas são iniciadas da posição 0. $O$ estado da linha 0 é o estado $B$ e o estado da linha 68 é o estado $E$. A coluna 0 representa a primeira posição da sequência e a coluna "tamanho da sequência - 1" representa a última posição da sequência.

A classe NoHints, subclasse de ExtrinsicTechique no padrão STRATEGY (Figura 6.6), não usa informações extrínsecas de alinhamento. Para modelar na matriz de contribuição extrínseca essa capacidade de também não utilizar informações extrínsecas, a matriz da classe NoHints é gerada com todos os seus campos com valores iguais a 1. Assim, essa matriz mesmo se usada no algoritmo Viterbi GHMM (Figura 6.3) não exerce influência de contribuição nas probabilidades dos estados durante o processo de rotulação. Esse efeito é equivalente a realizar uma predição ab initio similar a do MYOP.

A classe Augustus, subclasse de ExtrinsicTechique usa dois arquivos para construir a matriz de contribuição. Um arquivo com os valores treinados de contribuição de q + e q- de cada 
tipo de dica (hint) e outro arquivo gff com as localizações de cada dica nas sequência alvo. Cada linha desse gff é armazenada numa estrutura de dados a qual destaca-se as informações do tipo de dica presente na coluna feature do gff e o intervalo da sequência alvo a qual a dica está associado obtido pela diferença dos valores das colunas start e end de uma mesma linha do gff. O arquivo gff como um todo é armazenado num vetor dessa estrutura.

A construção da matriz é realiza um linha por vez. Para cada elemento da estrutura presente no vetor, é analisado o tipo da dica para determinar as linhas (estados associados) que receberão a contribuição e também é analisado o intervalo (diferença entre end e start) para determinar as colunas da matriz que receberão a contribuição referente ao tipo da dica. Esse processo de atribuir a contribuição na matriz nas colunas referentes ao intervalo e nas linhas referentes aos tipos de dicas associadas aos estados é repetido para cada elemento do vetor e a matriz é concluída depois que todos os elementos presentes no vetor são processados. A Tabela 6.2 mostra a associação de tipos de dicas e estados da GHMM (Figura 6.5).

\begin{tabular}{|l|l|}
\hline tipo de dica & estados associados \\
\hline start & start, rstart \\
\hline stop & stop, rstop \\
\hline & E00, E01, E02, E10, E11, E12, E20, E21, E22, \\
& EI0, EI1, EI2, ET0, ET1, ET2, \\
rE00, rE01, rE02, rE10, rE11, rE12, rE20, rE21, rE22, \\
& rEI0, rEI1, rEI2, rET0, rET1, rET2, \\
& ES, rES \\
& start, rstart \\
\hline ass & acc0, acc1, acc2, racc0, racc1, racc2 \\
\hline dss & don0, don1, don2, rdon0, rdon1, rdon2 \\
\hline intron & I0, I1, I2, Is0, If0, Is1, If1, Is2, If2, rI0, rI1, rI2, rIs0, rIf0, rIs1, rIf1, rIs2, rIf2 \\
& acc0, acc1, acc2, racc0, racc1, racc2, don0, don1, don2, rdon0, rdon1, rdon2 \\
\hline
\end{tabular}

Tabela 6.1: Esta tabela associa o tipo de dica e os estados aos quais ele exerce influência de contribuição. $N a \tilde{o}$ é mostrado os estados silenciosos ( $B$ e E) e estado de região intergenica $(N)$, pois esses não recebem contribuições extrínsecas

A classe Twinscan, subclasse de ExtrinsicTechique no padrão STRATEGY (Figura 6.6) usa a sequência de conservação e 5 arquivos com os trechos de sequência de conservação de treinamento referentes as regiões de éxon, éxon reverso, íntron, íntron reverso e região intergênica para treinar as respectivas Cadeias de Markov de ordem 5 para construir a matriz de contribuição.

Assim como na classe Augustus, a construção da matriz é realizada uma linha por vez. Cada campo das linhas da matriz de contribuição é construído com o valor de probabilidade de cada posição da sequência de conservação (construída a partir da sequência alvo e das sequências informantes) dado o modelo treinado referente ao estado. Por exemplo, as linhas da matriz referentes aos estados de éxon receberão os valores da probabilidade de cada posição da sequência de conservação dado o modelo de éxon, e as linhas da matriz referentes aos estados de íntrons receberão os valores da probabilidade de cada posição da sequência de conservação dado o modelo de íntron. Isso será feito para os estados (linhas da matriz) com seus modelos treinados associados. 


\begin{tabular}{|l|l|}
\hline sequência de conservação & estados associados \\
\hline \multirow{3}{*}{ cds } & E00, E01, E02, E10, E11, E12, E20, E21, E22, \\
& EI0, EI1, EI2, ET0, ET1, ET2, \\
& ES, start, stop \\
\hline \multirow{3}{*}{ cds reverso } & rE00, rE01, rE02, rE10, rE11, rE12, rE20, rE21, rE22, \\
& rEI0, rEI1, rEI2, rET0, rET1, rET2, \\
& rES, , rstart, rstop \\
\hline \multirow{2}{*}{ intron } & $\mathrm{I} 0, \mathrm{I} 1, \mathrm{I} 2, \mathrm{Is} 0$, If0, Is1, If1, Is2, If2, \\
& acc0, acc1, acc2, don0, don1, don2 \\
\hline \multirow{2}{*}{ intron reverso } & $\mathrm{rI0,} \mathrm{rI1,} \mathrm{rI2,} \mathrm{rIs0,} \mathrm{rIf0,} \mathrm{rIs1,} \mathrm{rIf1,} \mathrm{rIs2,} \mathrm{rIf2,}$ \\
& racc0, racc1, racc2, rdon0, rdon1, rdon2 \\
\hline intergênico & $\mathrm{N}$ \\
\hline
\end{tabular}

Tabela 6.2: Esta tabela associa cada um dos 5 conjuntos de trechos (de sequência de conservação de treinamento) usados para treinar as 5 Cadeias de Markov de ordem 5 e os estados aos quais essas Cadeias de Markov exercem influência de contribuição. Não é mostrado os estados silenciosos (B e E), pois esses não recebem contribuições extrínsecas 


\section{Capítulo 7}

\section{Validações e comparações}

Neste capítulo apresentamos os testes e validações realizados com o intuito de verificar a implementação unificada no MYOP $\mathrm{C}++$ dos algoritmos de inclusão de dados externos utilizados nos preditores Twinscan e Augustus.

O objetivo da validação é comparar os resultados dos algoritmos de Augustus e Twinscan implementados no MYOP C ++ discutidos no Capítulo 6 com os resultados do algoritmos implementados nos preditores originais. Contudo, isso não foi possível.

Tanto o preditor Augustus quanto o Twinscan possuem heurísticas e estratégias de implementação particulares o que torna muito difícil de se reproduzir numa implementação unificada. O preditor Augustus não implementa o modelo de contribuição extrínseca descrito na Equação 5.7, há um arquivo de configuração predefinido com o valores não probabilísticos de contribuição de cada tipo de dica. O preditor Twinscan não realiza predições sem o uso de informações extrínsecas e com isso não é possível avaliar o ajuste que essas informações propiciam em relação predições sem as mesmas. Por conta desses problemas, decidimos apenas comparar os algoritmos implementados na própria estrutura do ToPS e avaliar o melhoria que as informações de alinhamento fornecem na predição.

\subsection{Datasets}

O dataset de treinamento e de validação consiste num conjunto de 2000 genes validados e de referência (obtidos do RefSeq ${ }^{1}$ ) de $A$. thaliana, organismo modelo para o qual todos os preditores provêm modelos de predição. Separamos aleatoriamente 1600 genes para treinamento e 400 para validação. Não foi possível realizar validação cruzada porque o MYOP $\mathrm{C}++$ foi construído com as classes do ToPS refatorado e, no momento da finalização deste trabalho, o algoritmo Viterbi (método viterbi da classe GeneralizedHiddenMarkovModel) ainda está com tempo de execução muito alto o que impede uma experimentação com datasets maiores.

O dataset de sequências extrínsecas usado na validação do algoritmo Augustus consiste num conjunto com mais de 50 mil transcritos de A. thaliana e o dataset usado na validação do algoritmo Twinscan consiste num conjunto de 8 mil genes do genoma de Glycine max, uma planta filogeneticamente próxima a $A$. thaliana com anotação do genoma de alta qualidade, que foi usado como genoma informante. Os dois datasets de sequências extrínsecas são validados e de referência:

\footnotetext{
${ }^{1}$ https://www.ncbi.nlm.nih.gov/refseq/
} 
o dataset de transcritos de A. thaliana foi obtido do banco TAIR ${ }^{2}$ (The Arabidopsis Information Resource) e dataset de Glycine max obtido do banco RefSeq.

Executamos os preditores MYOP e Augustus com os 400 genes de validação para selecionar sequências onde o gene foi predito igual pelos dois preditores mas em desacordo com o gene referência, visando medir a melhoria em ambos os preditores com o uso de sequências informantes a partir de um mesmo resultado. Dos 400 genes selecionamos um total de 55 genes para os quais as predições de MYOP e Augustus foram exatamente iguais, porém erradas em ambos os preditores. Escolhemos os genes para validação dessa maneira por dois motivos: i) não adiantaria selecionar os genes aos quais tanto MYOP quanto Augustus têm predições iguais e corretas, porque uma reavaliação desses genes fornecendo as informações extrínsecas não mudaria as predições já corretas; ii) queríamos medir os efeitos causados exclusivamente pelo modelo de inclusão de dados extrínsecos e não diferenças nos preditores. Como já dito, o tamanho do dataset de validação foi influenciado pelo tempo de execução das predições do MYOP $\mathrm{C}++$.

O processo de seleção acima não foi repetido com o MYOP e Twinscan pois não é possível realizar predições com o este último sem utilizar a sequência de conversação (sequência com o as informações de alinhamento) junto com a sequência alvo. Desta maneira apenas utilizamos o mesmo conjunto de genes selecionado para comparação MYOP/Augustus, o que possibilita uma comparação entre os dois tipos de informação extrínseca no MYOP.

\subsection{Metodologia de validação}

Para determinar os 55 genes usados na validação, usamos a ferramenta SGEval ${ }^{3}$ que fornece medidas de exatidão, comparando arquivos gtf de predição com arquivos gtf de anotação de referência. SGEval agrupa arquivos gtf em conjuntos. Selecionamos para realizar a validação um conjunto de genes para os quais as predições do MYOP original e do Augustus eram idênticas, porém que diferentes da anotação de referência. Dessa forma, selecionamos os 55 genes do conjunto de teste cujas predições dos dois preditores foram iguais, porém incorretas.

Treinamos o MYOP C ++ com um dataset de 1600 genes e realizamos a validação da implementação do algoritmo Augustus, o algoritmo de inclusão de informação extrínseca utilizado pelo preditor Augustus, implementado no MYOP $\mathrm{C}++$ utilizando as dicas obtidas dos dados de alinhamento de transcritos ( 55 arquivos hints . gff com as dicas relativas à região genômica de cada um dos 55 genes). Também realizamos a validação do algoritmo Twinscan, o algoritmo de inclusão de informação extrínseca utilizado pelo preditor Twinscan, implementado no MYOP C ++ predizendo os mesmo 55 genes do dataset de teste anterior junto com as suas informações de alinhamento genômico ( 55 sequências de conservação de cada um dos 55 genes). Finalmente, para avaliar a melhoria relativa de cada abordagem, realizamos também a predição desses mesmos 55 genes com o algoritmo NoHints implementado no MYOP $\mathrm{C}++$, que representa uma predição ab initio sem o uso qualquer informação extrínseca.

A Figura 7.1 mostra o fluxograma geral do processo de validação.

\footnotetext{
${ }^{2}$ https://arabidopsis.org/index.jsp

${ }^{3}$ https://github.com/ayoshiaki/sgeval
} 


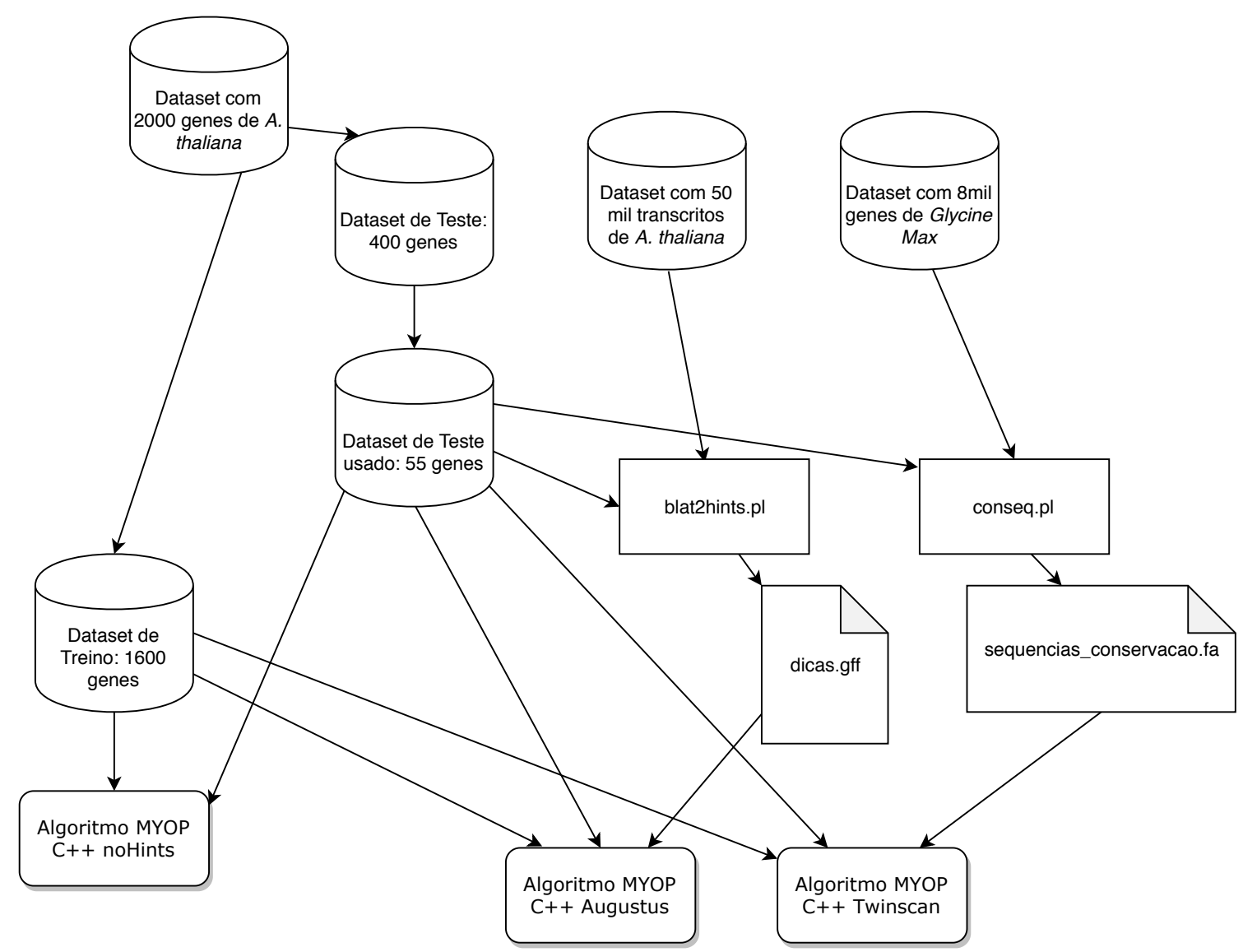

Figura 7.1: O dataset é dividido em dataset de treino e dataset de teste. Do dataset de teste foram selecionados 55 genes para compor o dataset de teste final. Os mesmos datasets de treino e de teste (com 55 genes) são usados no treinamento e teste dos três algoritmos implementados. Nesse fluxo, o que difere os algoritmos Augustus e Twinscan são os datasets de sequências extrínsecas e os scripts para o processamento das mesmas. Para o algoritmo Augustus é usado o dataset de transcritos e o script blat2hints.pl, e para o algoritmo Twinscan é usado o dataset com genes do genoma informante e o script conseq.pl.

\subsection{Validação do algoritmo Augustus implementado no MYOP C ++}

O preditor Augustus disponível atualmente não implementa o modelo de contribuição extrínseca descrito no artigo original, expresso na Equação 5.7; são disponibilizados apenas arquivos de configuração predefinidos, com valores não probabilísticos de contribuição para cada tipo de dica. Estes arquivos parecem descrever valores arbitrários obtidos de maneira heurística, dada a uniformidade dos valores apresentados. A documentação do preditor não esclarece o processo de cálculo destes valores. A Figura 7.2 mostra um arquivo ${ }^{4}$ de configuração do Augustus a qual estão descritos os valores de contribuição de cada tipo de dica:

\footnotetext{
${ }^{4}$ https://github.com/Gaius-Augustus/Augustus/blob/master/config/extrinsic/extrinsic.ME.cfg
} 


\begin{tabular}{|c|c|c|c|c|c|c|c|c|}
\hline start & 1 & 1 & $\mathrm{M}$ & 1 & $1 e+100$ & $\mathrm{E}$ & 1 & 1 \\
\hline stop & 1 & 1 & M & 1 & $1 e+100$ & $\mathrm{E}$ & 1 & 1 \\
\hline tss & 1 & 1 & M & 1 & $1 e+100$ & $\mathrm{E}$ & 1 & \\
\hline tts & 1 & 1 & M & 1 & $1 e+100$ & $\mathrm{E}$ & 1 & \\
\hline ass & 1 & 1 & M & 1 & $1 e+100$ & $\mathrm{E}$ & 1 & \\
\hline dss & 1 & 1 & M & 1 & $1 e+100$ & $\mathrm{E}$ & 1 & \\
\hline exonpart & 1 & 0.995 & M & 1 & $1 e+100$ & $\mathrm{E}$ & 1 & $1 e 3$ \\
\hline exon & 1 & 1 & M & 1 & $1 e+100$ & $\mathrm{E}$ & 1 & $1 e 4$ \\
\hline intronpart & 1 & 1 & M & 1 & $1 e+100$ & $\mathrm{E}$ & 1 & \\
\hline intron & 1 & 0.1 & M & 1 & $1 e+100$ & $\mathrm{E}$ & 1 & $1 e 4$ \\
\hline CDSpart & 1 & 1 & M & 1 & $1 e+100$ & $E$ & 1 & \\
\hline $\mathrm{CDS}$ & 1 & 1 & M & 1 & $1 e+100$ & $\mathrm{E}$ & 1 & $\perp$ \\
\hline UTRpart & 1 & 1 & M & 1 & $1 e+100$ & $\mathrm{E}$ & 1 & $\perp$ \\
\hline UTR & 1 & 1 & $\mathrm{M}$ & 1 & $1 e+100$ & $\mathrm{E}$ & 1 & $\perp$ \\
\hline irpart & 1 & 1 & M & 1 & $1 e+100$ & $\mathrm{E}$ & 1 & $\perp$ \\
\hline nonexonpart & 1 & 1 & $\mathrm{M}$ & 1 & $1 e+100$ & $\mathrm{E}$ & 1 & \\
\hline genicpart & 1 & 1 & M & 1 & $1 e+100$ & $\mathrm{E}$ & 1 & \\
\hline
\end{tabular}

Figura 7.2: Um exemplo de arquivo de configuração extrínseca disponível no preditor Augustus. Notase valores de contribuição extrínseca extremamente altos $(1 e+100)$ para todos os tipos de dicas de origem manual. Isso força a predição a obedecer as dicas manuais (M). Nota-se também valores 1000 (1e3) para dicas de trecho de éxon (exonpart) e valores 10000 (1e4) para dicas de éxon completo (exon) e de intron completo (intron) originadas de alinhamentos com ESTs (E).

Não há justificativa destes valores na documentação do preditor e tentativas de contato com os autores foram infrutíferas. Além disso, não foram apresentadas no artigo original fórmulas para o cálculo dos valores probabilísticos associados à quaisquer dicas que não aquela do exemplo (start). Desta forma, foi necessário inferir fórmulas para o cálculo destas probabilidades, que serão descritas a seguir. Além disso uma performance inicial muito ruim do uso das dicas nos levou a propor algumas modificações, como descrito abaixo:

1. uma análise da Equação 5.5 revela que ela parece indicar a sensibilidade ${ }^{5}$ (sensitity or recall) como o valor de contribuição da dica. Contudo, acreditamos que essa métrica não é a melhor para ser usada. Uma dica pode ser pouco sensível, ou seja aparecer pouco na sequência alvo, mas ter uma confiabilidade muito alta. Testes iniciais apresentaram performance muito ruim, o que pareceu confirmar nosso entendimento. Desta maneira, substituímos a sensibilidade pelo valor de predições positivas (positive prediction value - PPV) nestas sequências, associando a cada posição onde ocorre uma dica a taxa de sucesso deste tipo de dica para indicação da região.

2. no cálculo das equações de $q^{-}(t, g)$, substituímos o valor sugerido, trocando o denominador, que indicava todos os falsos positivos do conjunto de treinamento, por apenas a taxa de falsos positivos nas regiões onde dicas ocorreram no conjunto de treinamento. Novamente esta mudança foi motivada pela baixa performance em nossos testes iniciais.

3. no conjunto de treinamento para os parâmetros, restringimos, para cada região gênica, as dicas de apenas um transcrito, aquele com maior aderência à anotação original. Neste caso, o uso

\footnotetext{
${ }^{5} \mathrm{SN}=\frac{T P}{T P+F N}$, sensibilidade $(\mathrm{SN})$ é a razão entre os verdadeiros positivos $(\mathrm{TP})$ e a soma dos verdadeiros positivos e falsos negativos $(\mathrm{FN})$
} 
de informações conflitantes efetivamente tornava a existência de dicas prejudicial à predição, invalidando o efeito de dicas que poderiam contribuir para melhora da predição, diminuindo de fato a probabilidade do caminho correto.

4. por motivo semelhante ao item anterior, reduzimos para cada posição à indicação de apenas uma dica, pois a existência de mais de uma dica compatível (exemplo: dss e íntron) tinha como consequência a redução da probabilidade do estado indicado em relação à alternativa da existência de apenas uma dica. Como dicas de $d s s$ (dicas de sítio doador de íntron) e de ass (dicas de sítio aceitador de íntron) para uma determinada posição sempre eram coocorrentes com dicas de íntron, as primeiras foram removidas utilizando somente as probabilidades associadas as dicas de íntron nestes casos.

5. removemos também as dicas do tipo ep (dicas de trecho de éxon). Essas dicas em sua maioria mapeiam no início do éxon inicial e o no fim do éxon final, e essas regiões do éxon podem ou não fazer parte da região traduzida do gene (CDS). Desta maneira este tipo de dica é compatível tanto com estados de CDS, quanto com estado de UTR (se houver) ou intergênico, na ausência deste último. Isso acaba confundindo a predição nesses trechos e reduzindo a precisão do preditor..

6. fizemos novo cálculo para $q^{+}(X=\psi)$, para excluir as regiões intergênicas, uma vez que estas nunca possuem dicas e não deveriam ser usadas na contagem do denominador. Com isso $q^{+}(X=\psi)$ representa a probabilidade de não se ter uma dica numa posição do gene (em particular regiões de CDS e de íntrons).

Assim, por exemplo, dicas do tipo ep ou exon num trecho da sequência presente no arquivo de dicas são contabilizados como corretas se nesse mesmo intervalo houver uma anotação de CDS, caso contrário dicas de ep ou exon são considerados como erradas. Outro exemplo, dicas do tipo start presentes no arquivo de dicas são consideradas corretas se nesse mesmo intervalo na anotação de referência houver a anotação de start_codon e nesta posição da sequência houverem as bases ATG. Do mesmo modo, uma dica do tipo stop é considerada como correta se na anotação de referência constar nesta posição um stop_codon e no arquivo fasta o códon nesse intervalo é uma das três possibilidades de códon de stop: TAG, TAA ou TGA.

Abaixo a nova definição formal para os valores probabilísticos associados às dicas:

$$
q^{+}(X)=\frac{T P(X)}{T P(X)+F P(X)}
$$

onde $X \in T Y P E, T Y P E=\{$ start, stop, ass, dss, exon, ep, intron $\}, T P(X)$ é o número de dicas do tipo $X$ corretas, ou seja, que foram confirmados na anotação de referência e $F P(X)$ é o número de dicas do tipo $X$ falsas, ou seja, que não foram confirmadas na anotação de referência.

Para $X=\psi$, ou seja, a estimativa de probabilidade de não haver uma dica numa posição:

$$
q^{+}(X=\psi)=\frac{n \_n c l-n \_d i c a s}{n \_n c l},
$$

onde $n \_n c l$ é o número de nucleotídeos das regiões dos genes da sequência alvo e $n \_d i c a s$ é o número de nucleotídeos da sequência que receberam alguma dica. O valor $q^{-}(X=\psi)$ não é aplicável, pois 
corresponderia à probabilidade de uma dica não ocorrer onde não deveria ocorrer uma dica, assim ele não é calculado.

Para $X \neq \psi$, temos que:

$$
q^{-}(X)=\frac{F P(X)}{T N(X)}
$$

onde $F P(X)$ é o número de dicas do tipo $X$ que não foram confirmadas na anotação. O cálculo de $T N(X)$ é feito de duas maneiras diferentes que dependem do subconjunto de TYPE a qual a dica $X$ pertence. Para $X \in\{$ start, stop, ass, dss $\}$, temos dicas correspondentes a trechos do gene com restrição de conteúdo (apenas alguns determinados códons podem ser start ou ser stop códons, e apenas algumas sequências consenso de dois nucleotídios intrônicos vizinhos podem ser $d s s$ e ass). Desta maneira para o cálculo do valor $T N(X)$ consideramos apenas as posições no conjunto de treinamento onde ocorrem as sequências consenso. Por outro lado, para o cálculo do valor $T N(X)$ para $X \in\{$ exon, ep,ntron $\}$, utilizamos todas as posições das regiões de CDS e íntrons dos genes de treinamento.

Para $X \in\{$ exon, ep, intron $\}$ :

$$
T N(X)=n \_n c l-n \_\operatorname{dicas}(X),
$$

onde, $n \_$dicas $(X)$ é o número de nucleotídeos da sequência que receberam uma dica do tipo $X$.

Para $X \in$ \{start, stop, ass, dss $\}, T N(X)$ é o número de trechos da sequência as quais as bases desse trecho são compatíveis com a dica $\mathrm{X}$ onde não há um mapeamento de dica do tipo $X$ associado. Assim dado quando $X=d s s, T N(X)$ é o número de trechos da sequência com as bases GT (bases compatíveis com um trecho de sítio doador de íntron) e quando $X=$ ass, $T N(X)$ é o número de trechos da sequência com as bases AG (bases compatíveis com um trecho de sítio aceitador de íntron). Importante frisar que estas restrições são impostas pelo fato de que preditores de genes restringem a predição de sítios de splicing àqueles com as sequências consenso indicadas.

Desenvolvemos um script que calcula as nossas estimativas de $q^{+}$e $q^{-}$comparando os três arquivos de cada gene do conjunto de treinamento: o arquivo fasta da sequência, o arquivo gtf com a anotação de referência e o arquivo gff de dicas. Esse script realiza a contagem do número de dicas corretas e o número de dicas erradas de cada tipo e essa contagem é usada nos cálculos de $q^{+} \mathrm{e}$ $q^{-}$. Dicas corretas num trecho da sequência são dicas presentes no arquivo gff de dicas que acertam nesse trecho a anotação no arquivo gtf de referência e tem nesse mesmo trecho no arquivo fasta da sequência nucleotídeos compatíveis com a dica. Com essas contagens podemos obter uma estimativa do incremento fornecido pelos dados de alinhamento as predições.

As dicas usadas no algoritmo Augustus foram geradas pelo script blat2hints . $\mathrm{pl}^{6}$ a partir de cada um dos 55 genes e do seu respectivo alinhamento local. Cada um dos 55 genes foi alinhando usando BLAT contra o dataset de sequências extrínsecas, transcritos de A. thaliana. Esse script é fornecido junto com o próprio preditor Augustus.

Uma avaliação inicial mostrou que é comum obtermos dicas conflitantes, ou seja, dicas distintas que são compatíveis com estados diferentes do preditor. Isso ocorre por conta de mapeamentos incorretos ou splicing alternativo. Uma dica de éxon e uma de íntron na mesma posição acabam por confundir o preditor, que precisa encontrar apenas uma rotulação. Além disso, podemos também obter dicas redundantes, ou seja, na mesma posição pode haver mais de uma dica do mesmo tipo. Isso

\footnotetext{
${ }^{6}$ http://bioinf.uni-greifswald.de/augustus/binaries/scripts/
} 
cria, como já mencionamos anteriormente, um efeito deletério que diminui o valor de probabilidade. Por conta desses problemas, removemos as dicas redundantes e as dicas conflitantes nas validações de modo que cada posição da sequência do gene tenha somente uma dica.

Dividimos o dataset de validação de 55 genes em dois datasets. O dataset $1 \mathrm{com}$ as 48 genes que obtiverem dicas de alinhamento com o dataset de sequências extrínsecas de transcritos de $A$. thaliana e o dataset 2 com as 7 sequências restantes que não obtiveram dicas com os transcritos. Nos dois datasets realizamos predições com os algoritmos NoHints (sem informações de alinhamento) e Augustus implementados no MYOP $\mathrm{C}++$. No dataset 1 realizamos dois grupos de predições:

- no grupo 1 as predições dos 48 genes foram realizadas com os seus respectivos arquivos de dicas. Antes das predições esses arquivos passaram por um pré-processamento de limpeza a qual no máximo uma dica foi mantida por posição da sequência. Essas dicas foram chamadas de dicas limpas

- no grupo 2 as predições dos 48 genes foram realizadas usando a própria anotação de referência da sequência (gtf do gene) como arquivo de dicas. Essas dicas foram chamadas de dicas ideais.

No grupo 1 realizamos também dois conjuntos de 48 predições para avaliar o quão relevante é a contribuição estimada de cada tipo de dica. No primeiro conjunto as predições foram realizadas com as dicas limpas com as contribuições extrínsecas estimadas do dataset de treinamento de transcritos. Nos cálculos dessas estimativas de contribuição foram usadas as equações de $q^{+}(X)$ e $q^{-}(X)$ da seção anterior. No outro conjunto realizamos as predições com as mesmas dicas limpas, entretanto usamos as contribuições com valores "ideais", com valor de probabilidade igual a 1,0 .

A Figura 7.3 mostra o fluxograma do processo de validação do algoritmo Augustus. 


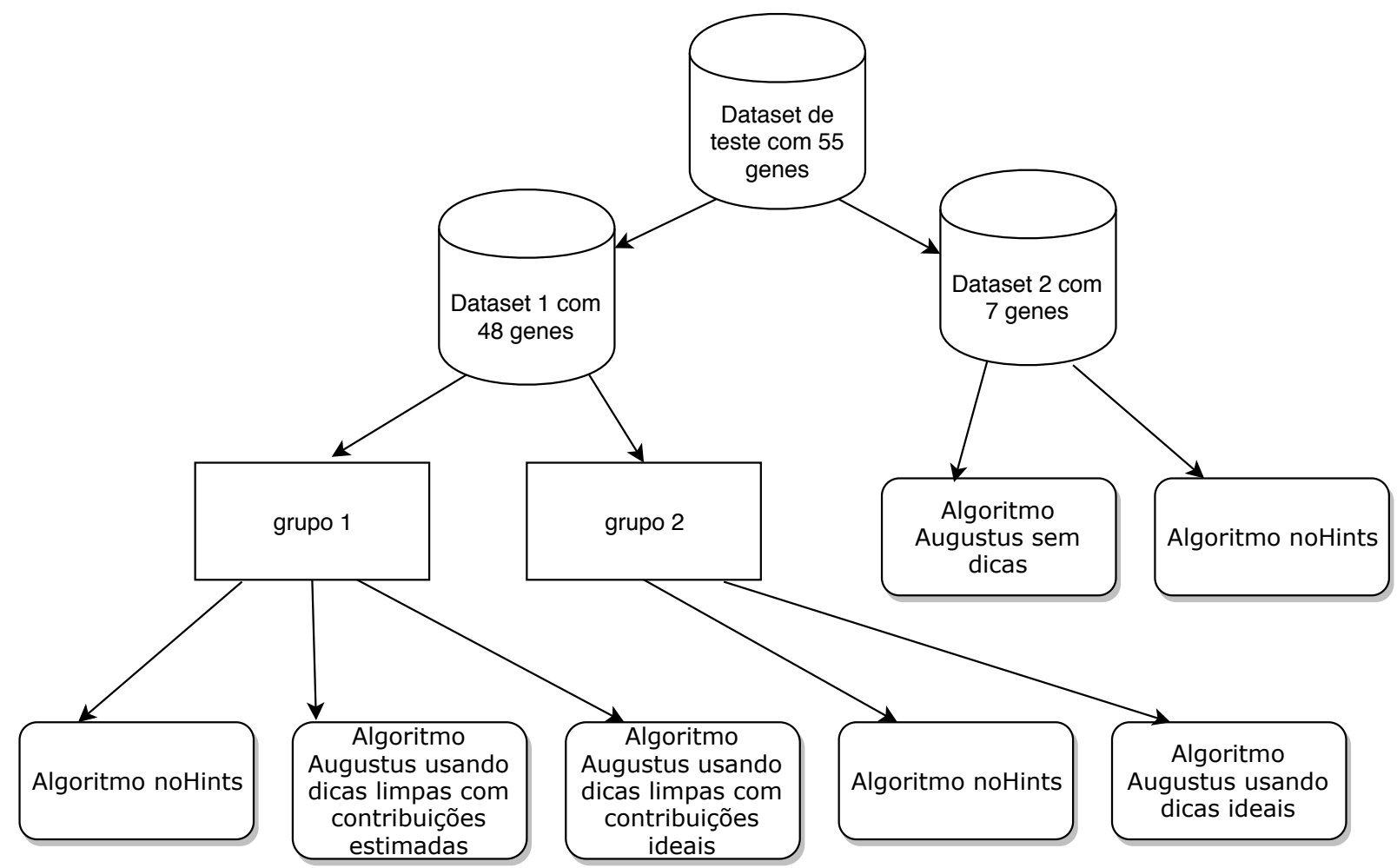

Figura 7.3: Nesse fluxograma em forma de árvore, as folhas representam os testes que foram realizados para validar o algoritmo Augustus implementado no MYOP $C_{+}+$. Com o mesmo dataset 1 foram realizados dois grupos de teste variando o conjunto de dicas utilizadas. No grupo 1 foram utilizadas as dicas limpas, que passaram pelo pré-processamento; e no grupo 2 foram utilizadas as dicas ideais, as anotações de referência dos 55 genes.

A Figura 7.4 mostra os resultados obtidos das predições do grupo 1 com o algoritmo Augustus e com o algoritmo original do preditor (NoHints).

\begin{tabular}{|l|r|r|r|r|r|}
\hline & \multicolumn{1}{|c|}{ Sem dicas } & Dicas limpas com contribuições estimadas & \multicolumn{2}{|c|}{ Dicas limpas com contribuições ideais } \\
\cline { 2 - 6 } & MYOP C++ NoHints & MYOP C++ Augustus & Ganho/Perda & MYOP C++ Augustus & Ganho/Perda \\
\hline Sensitivity nucleotide exon & 88,69 & 89,23 & 0,01 & 89,02 & 0,00 \\
PPV nucleotide exon & 70,71 & 77,85 & 0,10 & 78,10 & 0,10 \\
F-value nucleotide exon & 78,69 & 83,15 & 0,06 & 83,21 & 0,06 \\
Sensitivity nucleotide intron & 69,33 & 93,52 & 0,35 & 94,45 & 0,36 \\
PPV nucleotide intron & 63,74 & 68,52 & 0,07 & 67,27 & 0,06 \\
F-value nucleotide intron & 66,42 & 79,09 & 0,19 & 78,58 & 0,18 \\
Sensitivity nucleotide start codon & 25,00 & 18,75 & $-0,25$ & 18,75 & $-0,25$ \\
PPV nucleotide start codon & 23,53 & 18,37 & $-0,22$ & 17,65 & $-0,25$ \\
F-value ucleotide start codon & 24,24 & 18,56 & $-0,23$ & 18,18 & $-0,25$ \\
Sensitivity nucleotide stop codon & 35,42 & 29,17 & $-0,18$ & 33,33 & $-0,06$ \\
PPV nucleotide stop codon & 33,33 & 28,57 & $-0,14$ & 31,37 & $-0,06$ \\
F-value nucleotide stop codon & 34,34 & 28,87 & $-0,16$ & 32,32 & $-0,06$ \\
\hline
\end{tabular}

Figura 7.4: Tabela com os resultados das predições no grupo 1. No grupo 1, para as dicas limpas com contribuições estimadas, foram usados os seguintes fatores de multiplicação de cada tipo de dica: exon = 0.96091 , ep $=0.59867$, intron $=0.52541$, sem_dicas $=0.35185$. E no mesmo grupo 1 para as dicas limpas com contribuições ideais, foram usados os seguintes fatores: exon $=e p=$ intron $=1$ e sem_dicas $=0.35185$. Tanto nas dicas limpas com contribuições ideias quanto nas dicas com contribuições estimadas, os fatores de contribuição das dicas do tipo start e do tipo stop foram zero, pois essas dicas não apareceram nos mapeamentos e por isso não puderam ser estimados. As dicas do tipo ass e do tipo dss foram removidas durante a limpeza, dando preferência à permanência das dicas do tipo intron nos casos em ocorriam mais de uma dica na mesma posição da sequência. 
Os resultados das Figura 7.4 mostram que o uso de dicas, mesmo quando pré-processadas para evitar conflitos, diminui a precisão, a sensibilidade e o F-value das predições de start e stop códons. Acreditamos que isso ocorre por que essas dicas mapeiam da mesma maneira as regiões de UTR e de CDS. Para permitir o uso dessas dicas seria necessário um modelo de UTR dentro da estrutura da GHMM da estrutura do gene, porém tanto a GHMM do MYOP $\mathrm{C}++$ quanto MYOP original não modelam a região UTR. É importante salientar, porém, que temos melhoria na predição das regiões de éxon e íntron. Analisando os resultados como um todo não houve muita diferença das contribuições ideais e das estimadas, exceto nas métricas de stop códon com estimativas ideais as quais as perdas foram menores.

A Figura 7.5 mostra os resultados de avaliação do grupo 2 obtidos do algoritmos NoHints e do algoritmo Augustus e a Figura 7.6 reúne os resultados obtidos da avaliação algoritmo Augustus nos dois grupos.

\begin{tabular}{|l|r|r|r|}
\hline & \multicolumn{3}{|c|}{ Grupo 2 } \\
\cline { 2 - 4 } & \multicolumn{1}{|c|}{ Sem dicas } & \multicolumn{1}{|c|}{ Dicas Ideais } & \multicolumn{1}{c|}{ Ganho } \\
\cline { 2 - 4 } & MYOP C++ NoHints & \multicolumn{1}{|c|}{ MYOP C++ Augustus } & 0,06 \\
\hline Sensitivity nucleotide exon & 88,69 & 94,32 & 0,11 \\
PPV nucleotide exon & 70,71 & 78,36 & 0,09 \\
F-value nucleotide exon & 78,69 & 85,60 & 0,38 \\
Sensitivity nucleotide intron & 69,33 & 95,82 & 0,24 \\
PPV nucleotide intron & 63,74 & 79,13 & 0,31 \\
F-value nucleotide intron & 66,42 & 86,68 & 0,33 \\
Sensitivity nucleotide start codon & 25,00 & 33,33 & 0,21 \\
PPV nucleotide start codon & 23,53 & 28,57 & 0,27 \\
F-value nucleotide start codon & 24,24 & 30,77 & 0,59 \\
Sensitivity nucleotide stop codon & 35,42 & 56,25 & 0,45 \\
PPV nucleotide stop codon & 33,33 & 48,21 & 0,51 \\
\hline F-value nucleotide stop codon & 34,34 & 51,92 & \\
\hline
\end{tabular}

Figura 7.5: Tabela com os resultados das predições no grupo 2. No grupo 2, para dicas ideais, foram usados os seguintes fatores de multiplicação para cada tipo de dica: start $=$ stop $=$ exon $=e p=$ intron $=1 e$ sem_dicas $=0.35185$. O valor 0.35185 é uma estimativa utilizando o dataset de treinamento, onde 0.35185 das posições das sequências não foram mapeadas com dicas.

\begin{tabular}{|c|c|c|c|c|}
\hline & & \multicolumn{2}{|c|}{ Grupo 1} & \multirow{2}{*}{$\begin{array}{c}\text { Grupo } 2 \\
\text { Dicas Ideais }\end{array}$} \\
\hline & Sem dicas & Dicas limpas estimadas & Dicas limpas ideais & \\
\hline & MYOP C++ NoHints & MYOP C++ Augustus & MYOP C++ Augustus & MYOP C++ Augustus \\
\hline Sensitivity nucleotide exon & 88,69 & 89,23 & 89,02 & 94,32 \\
\hline PPV nucleotide exon & 70,71 & 77,85 & 78,10 & 78,36 \\
\hline F-value nucleotide exon & 78,69 & 83,15 & 83,21 & 85,60 \\
\hline Sensitivity nucleotide intron & 69,33 & 93,52 & 94,45 & 95,82 \\
\hline PPV nucleotide intron & 63,74 & 68,52 & 67,27 & 79,13 \\
\hline F-value nucleotide intron & 66,42 & 79,09 & 78,58 & 86,68 \\
\hline Sensitivity nucleotide start codon & 25,00 & 18,75 & 18,75 & 33,33 \\
\hline PPV nucleotide start codon & 23,53 & 18,37 & 17,65 & 28,57 \\
\hline F-value ucleotide start codon & 24,24 & 18,56 & 18,18 & 30,77 \\
\hline Sensitivity nucleotide stop codon & 35,42 & 29,17 & 33,33 & 56,25 \\
\hline PPV nucleotide stop codon & 33,33 & 28,57 & 31,37 & 48,21 \\
\hline F-value nucleotide stop codon & 34,34 & 28,87 & 32,32 & 51,92 \\
\hline
\end{tabular}

Figura 7.6: Todos os resultados dos dois grupos. As dicas ideais melhoram consideravelmente as predições em todas as métricas avaliadas enquanto as dicas limpas apresentam perdas e ganhos. 
Esses resultados mostram que o uso de dicas de alta confiabilidade aumenta a eficiência de predição de éxons, íntrons, códons de inicio e códons de fim nas três métricas avaliadas. Isso indica que o método proposto originalmente para uso no preditor Augustus apresenta sérios problemas, necessitando significativas modificações para mesmo assim apresentar resultados modestos. Apenas o uso de mapeamentos de altíssima confiabilidade parece exercer um fator positivo.

No dataset 2 formado por 7 das 55 sequências que não obtiveram dicas, realizamos a predição nos dois algoritmos(NoHints e Augustus) para comprovar que a implementação não apresenta perdas ou ganhos nas predições quando se usa algoritmo Augustus sem dicas. A Figura 7.7 mostra que isso ocorre, como o esperado.

\begin{tabular}{|c|c|c|}
\hline & \multicolumn{2}{|c|}{ Dataset 2} \\
\hline & Sem dicas & Sem dicas \\
\hline & MYOP C++ NoHints & MYOP C++ Augustus \\
\hline Sensitivity nucleotide exon & 91,21 & 91,21 \\
\hline PPV nucleotide exon & 80,15 & 80,15 \\
\hline F-value nucleotide exon & 85,32 & 85,32 \\
\hline Sensitivity nucleotide intron & 75,81 & 75,81 \\
\hline PPV nucleotide intron & 83,52 & 83,52 \\
\hline F-value nucleotide intron & 79,48 & 79,48 \\
\hline Sensitivity nucleotide start codon & 28,57 & 28,57 \\
\hline PPV nucleotide start codon & 25,00 & 25,00 \\
\hline F-value ucleotide start codon & 26,67 & 26,67 \\
\hline Sensitivity nucleotide stop codon & 57,14 & 57,14 \\
\hline PPV nucleotide stop codon & 50,00 & 50,00 \\
\hline F-value nucleotide stop codon & 53,33 & 53,33 \\
\hline
\end{tabular}

Figura 7.7: Resultado das predições em regiões sem dicas utilizando o algoritmo noHints e utilizando o algoritmo Augustus de inclusão de informação.

\subsection{Validação do algoritmo Twinscan implementado no MYOP C++}

Para validar o algoritmo Twinscan implementado no MYOP $\mathrm{C}++$, dividimos o dataset de validação de 55 sequências em dois datasets de maneira similar a realizada para a validação do algoritmo Augustus. O dataset 1 é formado por 48 sequências cujas suas sequências de conservação possuem pelo menos um carácter de match ("."), ou seja, pelo menos uma base do gene alinhou com o dataset do genomo informante. $\mathrm{O}$ dataset 2 é formado pelas 7 sequências restantes cujas respectivas sequências de conservação não possuem carácter de match. Importante destacar que, embora os número de sequências nos dataset 1 e 2 de validação dos algoritmos Augustus e Twinscan sejam os mesmos, cada dataset é formado por um subconjunto diferente do dataset de validação de 55 sequências.

No dataset 1 realizamos as 48 predições com o algoritmo Twinscan. Assim como na validação do algoritmo Augustus da seção anterior, realizamos as 48 predições também com o algoritmo NoHints nesse mesmo dataset 1 para fins de comparação e estimativas de ganhos e prejuízos alcançados.

As dicas usadas no algoritmo Twinscan foram geradas pelo script conseq.pl a partir do alinhamento dos 55 genes de validação de $A$. thaliana contra um dataset do genoma informante (Glycine max). Esse script é fornecido junto com o próprio preditor Twinscan ${ }^{7}$.

\footnotetext{
${ }^{7}$ http://mblab.wustl.edu/software.html
} 
A Figura 7.8 mostra o fluxograma do processo de validação dos algoritmos Twinscan.

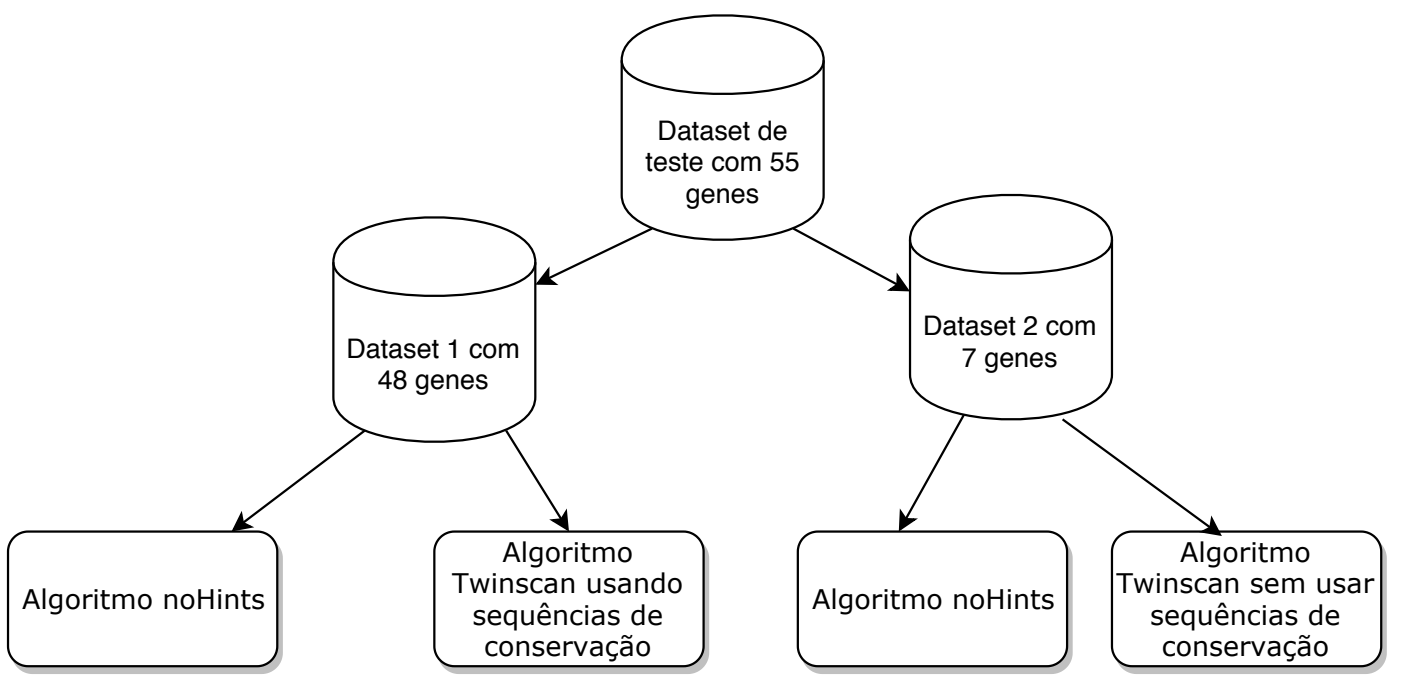

Figura 7.8: Nesse fluxograma em forma de árvore, as folhas representam os testes que foram realizados para validar o algoritmo Twinscan implementado no $M Y O P C++$. No dataset 1 foram realizadas predições usando as sequências de conservação geradas pelo script conseq.pl que obtiveram ao menos um caracter de match ("."). No dataset 2 foram realizadas predições sem o uso de sequências de conversação.

A Figura 7.9 mostra os resultados dessas predições.

\begin{tabular}{|l|r|r|r|}
\hline & \multicolumn{3}{|c|}{ Dataset 1 } \\
\cline { 2 - 4 } & MYOP C++ NoHints & MYOP C++ Twinscan & Ganho/Perda \\
\hline Sensitivity nucleotide exon & 66,22 & 66,13 & $-0,001$ \\
PPV nucleotide exon & 70,71 & 70,74 & 0,000 \\
F-value nucleotide exon & 68,39 & 68,36 & 0,000 \\
Sensitivity nucleotide intron & 44,36 & 44,40 & 0,001 \\
PPV nucleotide intron & 64,09 & 63,62 & $-0,007$ \\
F-value nucleotide intron & 52,43 & 52,30 & $-0,002$ \\
Sensitivity nucleotide start codon & 20,83 & 20,83 & 0,000 \\
PPV nucleotide start codon & 22,73 & 22,73 & 0,000 \\
F-value nucleotide start codon & 21,74 & 21,74 & 0,000 \\
Sensitivity nucleotide stop codon & 29,17 & 31,25 & 0,071 \\
PPV nucleotide stop codon & 31,82 & 34,09 & 0,071 \\
F-value nucleotide stop codon & 30,43 & 32,61 & 0,071 \\
\hline
\end{tabular}

Figura 7.9: Resultado das predições realizadas no dataset 1 utilizando a implementação do algoritmo Twinscan de uso de informação extrínseca de alinhamento genômico e das predições realizadas utilizando o algoritmo noHints

As dicas fornecidas pelo dataset do genoma informante resultaram em um ganho nas métricas de avaliação de sensibilidade, precisão (PPV) e f-value de nucleotídeos de stop códon. Porém, resultou numa discreta variação negativa, inferior a 1\%, nessas mesmas três métricas de avaliação de nucleotídeos de éxon, íntron e start códon.

Esses resultados indicam que o uso das sequências de conservação como dicas acarretou em pequeno mas significativo, em torno de 7\%, na caracterização de stop códons. Esta medida é particularmente interessante, pois garante que o fase de leitura estava correta no final da predição. 


\begin{tabular}{|c|c|c|}
\hline & \multicolumn{2}{|c|}{ Dataset 2} \\
\hline & Sem dicas & Sem dicas \\
\hline & MYOP C++ NoHints & MYOP C++ Twinscan \\
\hline Sensitivity nucleotide exon & 77,99 & 77,99 \\
\hline PPV nucleotide exon & 70,75 & 70,75 \\
\hline F-value nucleotide exon & 74,20 & 74,20 \\
\hline Sensitivity nucleotide intron & 64,75 & 64,75 \\
\hline PPV nucleotide intron & 56,29 & 56,29 \\
\hline F-value nucleotide intron & 60,22 & 60,22 \\
\hline Sensitivity nucleotide start codon & 28,57 & 28,57 \\
\hline PPV nucleotide start codon & 28,57 & 28,57 \\
\hline F-value nucleotide start codon & 28,57 & 28,57 \\
\hline Sensitivity nucleotide stop codon & 42,86 & 42,86 \\
\hline PPV nucleotide stop codon & 42,86 & 42,86 \\
\hline F-value nucleotide stop codon & 42,86 & 42,86 \\
\hline
\end{tabular}

Figura 7.10: Resultado de predições com e sem o algoritmo Twinscan de inclusão de informação extrínseca em regiões sem alinhamentos

No dataset 2, formado por 7 das 55 sequências que não obtiveram dicas do genoma informante de Glycine max, também realizamos a predição com os dois algoritmos ( Figura 7.10) para comprovar que não há perdas ou ganhos nessas predições. Novamente, os resultados comprovaram que não há perdas ou ganhos nas predições com o algoritmo Twinscan sem o fornecimento da sequência de conservação (a dica, a informação extrínseca de alinhamento do Twinscan) em relação a predição com o algoritmo NoHints. A Figura 7.11 reúne os resultados obtidos da avaliação dos algoritmos NoHints e Twinscan nos dois datasets.

\begin{tabular}{|l|r|r|r|r|}
\hline & \multicolumn{2}{|c|}{ Dataset 1 } & \multicolumn{2}{|c|}{ Dataset 2 } \\
\cline { 2 - 5 } & MYOP C++ NoHints & MYOP C++ Twinscan & MYOP C++ NoHints & MYOP C++ Twinscan \\
\hline Sensitivity nucleotide exon & 66,22 & 66,13 & 77,99 & 77,99 \\
PPV nucleotide exon & 70,71 & 70,74 & 70,75 & 70,75 \\
F-value nucleotide exon & 68,39 & 68,36 & 74,20 & 74,20 \\
Sensitivity nucleotide intron & 44,36 & 44,40 & 64,75 & 64,75 \\
PPV nucleotide intron & 64,09 & 63,62 & 56,29 & 56,29 \\
F-value nucleotide intron & 52,43 & 52,30 & 60,22 & 60,22 \\
Sensitivity nucleotide start codon & 20,83 & 20,83 & 28,57 & 28,57 \\
PPV nucleotide start codon & 22,73 & 22,73 & 28,57 & 28,57 \\
F-value nucleotide start codon & 21,74 & 21,74 & 28,57 & 28,57 \\
Sensitivity nucleotide stop codon & 29,17 & 31,25 & 42,86 & 42,86 \\
PPV nucleotide stop codon & 31,82 & 34,09 & 42,86 & 42,86 \\
F-value nucleotide stop codon & 30,43 & 32,61 & 42,86 \\
\hline
\end{tabular}

Figura 7.11: Todos os resultados de predição nos dois datasets. 


\section{Capítulo 8}

\section{Considerações finais e conclusão}

Neste trabalho aplicamos os conceitos de inclusão de informações de alinhamentos usados nos preditores Twinscan e Augustus para o desenvolvimento de um método para unificação em um único algoritmo de ambos os tipos de informação. A unificação proposta permite que a adição de novos algoritmos seja facilitada, bastando implementar uma nova classe que representa esse novo algoritmo na hierarquia de classes do padrão Strategy (Figura 6.6). Essa classe deve mapear um ou vários conjuntos de evidências externas e construir uma matriz de contribuição. O Strategy e as classes que realizam a conversão do mapeamento em valores de probabilidade (construção da matriz) foram implementados como extensão do ToPS, um arcabouço probabilístico orientado a objetos para análise de sequências.

Devido ao processo de refatoração ToPS foi preciso implementar uma versão reduzida do MYOP, chamada MYOP $\mathrm{C}++$, com a qual validamos as implementações de dois métodos e a unificação dos mesmo no ToPS. Os resultados de predição do MYOP $\mathrm{C}++$ apresentados apontam a necessidade de maiores estudos na modelagem e no uso das informações de alinhamento. Essas informações podem confundir o preditor e piorar os seus resultados de predição.

Uma análise dos resultados das predições com evidências extrínsecas nos dois modelos utilizados, Twinscan e Augustus, mostrou a dificuldade da inclusão destes dados de maneira efetiva. O efeito de piora provocado por informações extrínsecas de transcritos é percebido no algoritmo Augustus. Evidências de mapeamento sem indicação de regiões de UTR (3'ou 5') acabam por confundir os modelos, prejudicando ao invés de ajudar a predição do sítio de início de transcrição. O efeito de melhora é bem alto quando usamos a própria anotação como dicas. Contudo, sabemos que se a anotação de referência da sequência já é conhecida a predição da mesma não é mais necessária. Por outro lado, esse efeito de piora não é percebido no algoritmo Twinscan. Conseguimos uma melhora $7 \%$ nos resultados nas métricas de sensibilidade, precisão e f-score de stop códon e não obtivemos perdas ou ganhos nas outras regiões do gene, sendo necessário uma investigação mais aprofundada dos motivos.

Como limitações, as dificuldades oriundas da implementação do sistema MYOP C ++ e o custo computacional alto na execução dos algoritmos da GHMM do ToPS refatorado, atrasaram e dificultaram a realização de um grande número de experimentos. Porém, os resultados preliminares nos levam a acreditar que a base instalada por esse projeto permite que sejam executados mais experimentos em pesquisas futuras assim que a refatoração do ToPS seja concluída.

Trabalhos futuros podem se concentrar na produção de dicas com menos conflitos ou na limpeza automática das dicas geradas pelo script fornecido pelo preditor Augustus, a fim de evitar 
equívocos dos modelos. Novos métodos podem ser experimentados combinando as duas matrizes de contribuição extrínseca dos dois métodos implementados nesse trabalho. Além disso, é possível reduzir o número de linhas da matriz, pois várias delas tem valores que se repetem. 


\title{
Referências Bibliográficas
}

\begin{abstract}
Alberts et al.(2017) Bruce Alberts, Alexander Johnson, Julian Lewis, David Morgan, Martin Raff, Keith Roberts, Peter Walter, John Wilson e Tim Hunt. Biologia Molecular da Célula. Artmed Editora, 6nd edição. Citado na pág. ix, x, 5, 7, 8, 9, 11
\end{abstract}

Angelova et al.(2010) Mihaela Angelova, Slobodan Kalajdziski e Ljupco Kocarev. Computational methods for gene finding in prokaryotes. ICT Innovations, páginas 11-20. Citado na pág. 22

Axelson-Fisk(2015) Marina Axelson-Fisk. Comparative Gene Finding: Models, Algorithms and Implementation. Springer, $2^{\mathrm{o}}$ edição. Citado na pág. ix, 5, 10, 21, 24

Batzoglou et al.(2000) Serafim Batzoglou, Lior Pachter, Jill P Mesirov, Bonnie Berger e Eric S Lander. Human and mouse gene structure: comparative analysis and application to exon prediction. Genome research, 10(7):950-958. Citado na pág. 23

Bernardi(2000) Giorgio Bernardi. Isochores and the evolutionary genomics of vertebrates. Gene, 241(1):3-17. Citado na pág. 24

Blattner et al.(1997) Frederick R Blattner, Guy Plunkett, Craig A Bloch, Nicole T Perna, Valerie Burland, Monica Riley, Julio Collado-Vides, Jeremy D Glasner, Christopher K Rode, George F Mayhew et al. The complete genome sequence of escherichia coli k-12. science, 277(5331):14531462. Citado na pág. 8

Blumenthal(2004) Thomas Blumenthal. Operons in eukaryotes. Briefings in Functional Genomics, 3(3):199-211. Citado na pág. 9

Bonadio(2018) Ígor Bonadio. Algoritmos eficientes para análise de campos aleatórios condicionais semi-markovianos e sua aplicação em sequências genômicas. Tese de Doutorado, Universidade de São Paulo. Citado na pág. 40

Bonadio(2013) Ígor Bonadio. Desenvolvimento de um arcabouço probabilístico para implementação de campos aleatórios condicionais. Dissertação de Mestrado, Universidade de São Paulo. URL http://igorbonadio.com.br/files/dissertacao-igor.pdf. Citado na pág. 40

Boratyn et al.(2013) Grzegorz M Boratyn, Christiam Camacho, Peter S Cooper, George Coulouris, Amelia Fong, Ning Ma, Thomas L Madden, Wayne T Matten, Scott D McGinnis, Yuri Merezhuk et al. Blast: a more efficient report with usability improvements. Nucleic acids research, $41(\mathrm{~W} 1)$ : W29-W33. Citado na pág. 29

Burge e Karlin(1997) Chris Burge e Samuel Karlin. Prediction of complete gene structures in human genomic dna1. Journal of molecular biology, 268(1):78-94. Citado na pág. 2, 24, 25

Cantarel et al.(2008) Brandi L Cantarel, Ian Korf, Sofia MC Robb, Genis Parra, Eric Ross, Barry Moore, Carson Holt, Alejandro Sánchez Alvarado e Mark Yandell. Maker: an easy-to-use annotation pipeline designed for emerging model organism genomes. Genome research, 18(1): 188-196. Citado na pág. 29 
Chin et al.(2006) David Chin, Glen M Boyle, David R Theile, Peter G Parsons e William B Coman. The human genome and gene expression profiling. Journal of Plastic, Reconstructive \& Aesthetic Surgery, 59(9):902-911. Citado na pág. 9

Cordeiro(2015) Renato Cordeiro. Refatoração do Arcabouço de Modelos Probabilísticos ToPS, 2015. Monografia do Trabalho de Conclusão de Curso (Bacharel em Ciência da Computação), Universidade de São Paulo. Citado na pág. 41

Costa et al.(2002) Vânia Aparecida da Costa, Maria Júlia Acedo, Newton Carlos Polimeno e Carmen Sílvia Bertuzzo. Contribuição para a estimativa da freqüência populacional da persistência hereditária da hemoglobina fetal no brasil. Cadernos de Saúde Pública, 18:1469-1471. Citado na pág. 2

Durbin et al.(1998) Richard Durbin, Sean R Eddy, Anders Krogh e Graeme Mitchison. Biological sequence analysis: probabilistic models of proteins and nucleic acids. Cambridge university press. Citado na pág. 13

Ferreira(2015) Rafael Mathias Ferreira. Arcabouço probabilístico para análise de sequências de rna. Dissertação de Mestrado, Universidade de São Paulo. Citado na pág. 41

Ferreira et al.(2016) Renato Cordeiro Ferreira, Ígor Bonadio e Alan Mitchell Durham. Secretary pattern: decreasing coupling while keeping reusability. Em Proceedings of the 11th Latin-American Conference on Pattern Languages of Programming, página 14. The Hillside Group. Citado na pág. 41

Finn et al.(2016) Robert D Finn, Penelope Coggill, Ruth Y Eberhardt, Sean R Eddy, Jaina Mistry, Alex L Mitchell, Simon C Potter, Marco Punta, Matloob Qureshi, Amaia Sangrador-Vegas et al. The pfam protein families database: towards a more sustainable future. Nucleic acids research, 44(D1):D279-D285. Citado na pág. 29

Gamma et al.(1995) Erich Gamma, Richard Helm, Ralph Johnson e John Vlissides. Design patterns: elements of reusable object-oriented software, volume 47. Addison-Wesley Longman Publishing Co., Inc. ISBN 0-201-63361-2. doi: 10.1016/j.artmed.2009.05.004. Citado na pág. 3, 41, 47

Gollery(2005) Martin Gollery. Bioinformatics: Sequence and Genome Analysis, David W. Mount. Cold Spring Harbor, NY: Cold Spring Harbor Laboratory Press, 2004, 692 pp., ISBN 0-87969712-1., volume 51. Clinical Chemistry. Citado na pág. 22

Haas et al.(2003) Brian J Haas, Arthur L Delcher, Stephen M Mount, Jennifer R Wortman, Roger K Smith Jr, Linda I Hannick, Rama Maiti, Catherine M Ronning, Douglas B Rusch, Christopher D Town et al. Improving the arabidopsis genome annotation using maximal transcript alignment assemblies. Nucleic acids research, 31(19):5654-5666. Citado na pág. 22

Hu e Brent(2003) Ping Hu e Michael $\mathrm{R}$ Brent. Using twinscan to predict gene structures in genomic dna sequences. Current Protocols in Bioinformatics, 3(1):4-8. Citado na pág. 31

Kashiwabara(2012) André Yoshiaki Kashiwabara. MYOP/ToPS/SGEval: Um ambiente computacional para estudo sistemático de predição de genes. Tese de Doutorado, Universidade de São Paulo. Citado na pág. x, xii, 25, 44, 46

Kashiwabara et al.(2013) André Yoshiaki Kashiwabara, Igor Bonadio, Vitor Onuchic, Felipe Amado, Rafael Mathias e Alan Mitchell Durham. Tops: a framework to manipulate probabilistic models of sequence data. PLoS computational biology, 9(10):e1003234. Citado na pág. 3, 40, 44

Kent(2002) W James Kent. Blat - the blast-like alignment tool. Genome research, 12(4):656-664. Citado na pág. 2, 22 
Korf et al.(2001) Ian Korf, Paul Flicek, Daniel Duan e Michael R Brent. Integrating genomic homology into gene structure prediction. Bioinformatics, 17(suppl_1):S140-S148. Citado na pág. xi, 2, 29, 31, 32

Larsen e Krogh(2003) Thomas Schou Larsen e Anders Krogh. Easygene-a prokaryotic gene finder that ranks orfs by statistical significance. BMC bioinformatics, 4(1):21. Citado na pág. $\mathrm{x}, 2$, 23,24

Lehninger et al.(2012) Albert L Lehninger, David L Nelson, Michael M Cox et al. Principles of Biochemistry. W.H. Freeman, 6 edição. Citado na pág. ix, 6

Lesk(2014) Arthur Lesk. Introduction to Bioinformatics. Oxford University Press, 4nd edição. Citado na pág. ix, 2, 5

Lukashin e Borodovsky(1998) Alexander V Lukashin e Mark Borodovsky. Genemark. hmm: new solutions for gene finding. Nucleic acids research, 26(4):1107-1115. Citado na pág. 29

Mathé et al.(2002) Catherine Mathé, Marie-France Sagot, Thomas Schiex e Pierre Rouzé. Current methods of gene prediction, their strengths and weaknesses. Nucleic acids research, 30(19):41034117. Citado na pág. 22

Min et al.(2017) Byoungnam Min, Igor V Grigoriev e In-Geol Choi. Fungap: Fungal genome annotation pipeline using evidence-based gene model evaluation. Bioinformatics, 33(18):29362937. Citado na pág. 29

Moreira(2015) LM Moreira. Ciências genômicas: fundamentos e aplicações. Citado na pág. ix, x, 8, 21

Muir et al.(2016) Paul Muir, Shantao Li, Shaoke Lou, Daifeng Wang, Daniel J Spakowicz, Leonidas Salichos, Jing Zhang, George M Weinstock, Farren Isaacs, Joel Rozowsky et al. The real cost of sequencing: scaling computation to keep pace with data generation. Genome biology, 17(1):53. Citado na pág. ix, 1

Rabiner(1989) Lawrence R Rabiner. A tutorial on hidden markov models and selected applications in speech recognition. Proceedings of the IEEE, 77(2):257-286. Citado na pág. 16

Sakharkar et al.(2004) Meena Kishore Sakharkar, Vincent TK Chow e Pandjassarame Kangueane. Distributions of exons and introns in the human genome. In silico biology, 4(4):387-393. Citado na pág. 19

Santos e Ortega(2003) Fabrício R Santos e José Miguel Ortega. Bioinformática aplicada à genômica. BIOWORK IV-Melhoramento Genômico. Citado na pág. 1

Simão et al.(2015) Felipe A Simão, Robert M Waterhouse, Panagiotis Ioannidis, Evgenia V Kriventseva e Evgeny M Zdobnov. Busco: assessing genome assembly and annotation completeness with single-copy orthologs. Bioinformatics, 31(19):3210-3212. Citado na pág. 29

Slater e Birney(2005) Guy St C Slater e Ewan Birney. Automated generation of heuristics for biological sequence comparison. BMC bioinformatics, 6(1):31. Citado na pág. 2, 22

Stanke e Waack(2003) Mario Stanke e Stephan Waack. Gene prediction with a hidden markov model and a new intron submodel. Bioinformatics, 19(suppl_2):ii215-ii225. Citado na pág. x, xi, 2, $22,25,26,27,28,33,36$

Stanke et al.(2006) Mario Stanke, Oliver Schöffmann, Burkhard Morgenstern e Stephan Waack. Gene prediction in eukaryotes with a generalized hidden markov model that uses hints from external sources. BMC bioinformatics, 7(1):62. Citado na pág. 2, 3, 22, 29, 31, 33, 36 
Stroustrup(2013) Bjarne Stroustrup. The $C++$ Programming Language, 4th Edition. AddisonWesley. ISBN 0321563840. Citado na pág. xii, 42

U.S. National Library of Medicine(2018) U.S. National Library of Medicine. What is a genome? https://ghr.nlm.nih.gov/primer/hgp/genome, 2018. Último acesso em 28/06/2018. Citado na pág. 1

Verli(2014) Hugo Verli. Bioinformática: da Biologia à Flexibilidade Molecular. Citado na pág. 22 